\title{
Yaari Dosti: Young Men Redefine Masculinity, A Training Manual [Hindi]
}

Horizons Program

CORO for Literacy

MAMTA

Instituto Promundo

Follow this and additional works at: https://knowledgecommons.popcouncil.org/departments_sbsr-hiv

Part of the Family, Life Course, and Society Commons, Gender and Sexuality Commons, and the International Public Health Commons

How does access to this work benefit you? Let us know!

\section{Recommended Citation}

Horizons Program, CORO for Literacy, MAMTA, and Instituto Promundo. 2006. "Yaari Dosti: Young Men Redefine Masculinity, A Training Manual [Hindi]." New Delhi: Population Council. 



\section{यारी दोस्ती : युवाओं द्वारा मर्दानगी की पुर्नव्याख्या एक अभ्यास पुस्तिका}

पॉपुलेशन काउंसिल, नई दिल्ली कोरो, (CORO), मुम्बई ममता, नई दिल्ली इंस्टीट्यूटो प्रोमुण्डो, ब्राजील

(2 Population Council ${ }_{\mathrm{H}}$ rizons
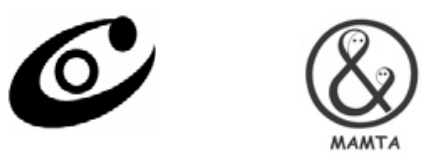

Promundo

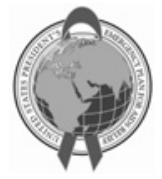

MACARTHUR

SSL International plc

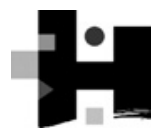


This training manual aims to promote gender equity and addresses masculinity as a strategy for the prevention of HIV infection. The Manual is based on operations research that was undertaken in Mumbai and Uttar Pradesh to develop educational activities targeted to young men.

For additional copies of this manual, please contact:

Population Council

142, Golf Links

New Delhi 110003

Tel: $+911141743410-11$

Fax: +911141743412

Email : vthomas@popcouncil.org

Website: www.popcouncil.org/horizons

South \& East Asia Regional Office

Zone 5A, India Habitat Centre

Lodi Road

New Delhi 110003

Tel: $+911124642901 / 02$

Fax: +911124642903

Email: info-india@ @opcouncil.org

The Population Council, an international, nonprofit, nongovernmental organization, seeks to improve the well-being and reproductive health of current and future generations around the world and to help achieve a humane, equitable, and sustainable balance between people and resources. The council conducts biomedical, social science and public health research, and helps build research capacities in developing countries.

\section{Copyright @ 2006 Population Council}

This document may be reproduced in whole or part without permission of the Population Council provided full source citation is given and reproduction is not for commercial purposes.

Suggested citation: Population Council, 2006. Yaari Dosti: Ek Abhyas Pushtika. New Delhi: Population Council. 


\section{विषय सूची}

प्रस्तावना

vii

आभार

ix

भूमिका

भाग 1 : सामाजिक लिंग

अभ्यास 1.1 : सामाजिक लिंग

अभ्यास 1.2 : लैंगिकता और प्रजनन

अभ्यास 1.3 : ठप्पा लगाना

अभ्यास 1.4 : व्यक्ति एवं वस्तुएं

अभ्यास 1.5 : घरेलू कामः हम सिर्फ तभी ध्यान देते हैं जब उन्हें नहीं किया जाता है 11

अभ्यास 1.6 : मेरी भावनाऐं

अभ्यास 1.7 : निर्णय लेने के कारण तथा भावनाएँ 17

अभ्यास 1.8 : जीवन की लॉटरी

भाग 2 : यौन तथा प्रजनन स्वास्थ्य

अभ्यास 2.1 : मैं और मेरा शरीर

अभ्यास 2.2 : प्रजननता और गर्भनिरोधक 27

अभ्यास 2.3 : बच्चे पैदा कर सकने वाला शरीर 31

अभ्यास 2.4 : यौन आकुलताः हो सके तो, जवाब दो... 36

अभ्यास 2.5 : रघु और पिंकी की कहानी 41

अभ्यास 2.6 : कामुक शरीर 44

अभ्यास 2.7 : सेहत, यौनरोग, एचआईवी तथा एड्स 47

अभ्यास 2.8 : क्या मैंने तुम्हें इस बारे में पहले बताया नहीं था 49

भाग 3 : हिंसा

अभ्यास 3.1 : यौन अत्याचार 55

अभ्यास 3.2 : यौन सबंधों में हिंसा और जोर जबरदस्ती 59 
अभ्यास 3.3 : विविधता एवं अधिकार - मैं तथा अन्य 61

अभ्यास 3.4 : अन्तरंग सम्बन्धों में हिंसा से सम्मान तक

अभ्यास 3.5 : हिंसा से शान्तिपूर्ण सह-अस्तित्व तक

अभ्यास 3.6 : मैं क्या करता हूँ जब मुझे गुस्सा आता है?

\section{भाग 4 : एच.आई.वी. तथा एड्स के साथ जीना और इसकी रोकथाम}

अभ्यास 4.1 : राजू की कहानी

अभ्यास 4.2 : दस्तखत की तलाश

अभ्यास 4.3 : मुझे भी यह हो सकता है यदि...

अभ्यास 4.4 : कुछ लोग कंडोम का इस्तेमाल ही नहीं करना चाहते क्योंकि 
"यारी दोस्ती : युवाओं द्वारा मर्दानगी की पुर्नव्याख्या : एक अभ्यास पुस्तिका" का संपादन पॉपुलेशन काउसिल ने संयुक्त रूप से इनस्ट्टियूटो प्रोमुण्डो, कोरो, ममता तथा दाउद के साथ किया। सरकारी तथा गैर सरकारी संरथान जो लैंगिक समानता और एच. आई. वी. से बचाव के संदर्भ में मर्दानगी जैसे विषयों पर कार्य कर रहें हैं, उनके लिए यह एक महत्वपूर्ण संग्रह है। इस अभ्यास पुस्तिका का एक सबल पक्ष यह है कि इसका सफल परीक्षण एवमं मूल्यांकन विभिन्न ग्रामीण तथा शहरी समुदायों में हो चुका है और वर्तमान में इसका इस्तेमाल भी हो रहा है।

यह अभ्यास पुस्तिका, ब्राजील में चलाए गए प्रोग्राम $\mathrm{H}$ पर आधारित है। प्रोग्राम $\mathrm{H}$ का क्रियान्वयन इनस्ट्युयूटो प्रोमुण्डो द्वारा किया गया तथा इस कार्यक्रम का मूल्यांकन पॉपुलेशन काउंसिल ने किया था। इस कार्यक्रम में मर्दानगी के साकारत्मक पक्ष को उभारने के अलावा लैंगिक तथा प्रजनन स्वार्थ्य में पुरूषों की भागीदारी, लैंगिक विषमताओं के प्रति सम्मान तथा लैंगिकता एवं शरीर के प्रति समझदारी को बढ़ावा दिया गया। इस अभ्यास पुस्तिका में एच. आई. वी. से बचाव की चर्चा लैंगिक जिम्मेवारी तथा अपसी रिश्तों के परिपेक्ष में किया गया है।

इस अभ्यास पुस्तिका में विभिन्न महत्वपूर्ण सामाजिक मुद्दों पर चर्चा की गयी है। इन मुद्दों को प्रमुख रूप से अग्रलिखित चार उपखंडो में बांटा गया है य (1) सामाजिक लिंग (2) यौन तथा प्रजनन स्वास्थ्य (3) हिंसा (4) एच. आई. वी. और एड्स के साथ जीना तथा इसकी रोकथाम। इस अभ्यास पुस्तिका का वर्तमान स्वरूप तीन सालों के सहभागी शोध का परिणाम है। भारत में इस अभ्यास पुस्तिका के व्यापक प्रसार के लिए इसका प्रकाशन हिंदी
में किया गया है। इसे और भी दूसरे क्षेत्रीय भाषाओं में रूपांतरित किया जा सकता है। में इस अभ्यास पुस्तिका के इस्तेमाल करने वालों को प्रोत्साहित करना चाहूँगी की इसे अपने क्षेत्रीय परिपेक्ष में इस्तेमाल करें जो की उस क्षेत्र विशेष के लिए उपयुक्त हो।

भारत में ज्यादातर लैंगिक तथा प्रजनन स्वास्थ्य संबंधी समस्याओं का मूल कारण समाज में फैली हुई लैंगिक विषमताऐं हैं। लैंगिक विषमताओं ने हमारे समाज में गहरी पकड़ बना ली है परन्तु अभी तक इससे संबंधित कुरीतियों को दूर करने में हमें मामूली सफलता ही हाथ लगी है। हालांकि कुछ महिला समूहों ने इन मुद्दों को उठाया है, पर उनका प्रयास प्रायः महिलाओं से संबंधित समस्याऐं और उनके जरूरतों पर सीमित रहा है। पर हमारे समाज में निहित स्त्री-पुरुष के अधिकार संबंधित विषमताओं जैसी समस्याओं को हम तब तक प्रभावी रूप से खत्म नहीं कर सकते जब तक हम पुरूषों को इसमें शामिल नहीं करेंगे। अभी तक इस दिशा में बहुत कम प्रयास हुए हैं तथा इससे संबंधित उदाहरणों की भी काफी कमी है। और इसलिए युवा पुरूषों को प्रभावी रूप से इन कार्यक्रमों में शामिल करने के लिए यह बेहद जरूरी है कि एक असरदार कार्यक्रम की रूपरेखा बनायी जाए ताकि इन कार्यक्रमों के मूल्यांकनों द्वारा हमें युवा पुरूषों को अच्छी तरह से समझने में सहायता मिल सके। यह अभ्यास पुस्तिका इस दिशा में एक प्रयास है। इस अभ्यास पुस्तिका का भारतीय अनुकूलन, मुंबई तथा उत्तर प्रदेश में चल रहे ऑपरेशन रिसर्च के अनुभवों पर आधारित है। इस पुस्तिका का इन समुदायों में लगातार मूल्यांकन किया गया तथा इस पुस्तिका को युवाओं तथा वहॉ के सामाजिक वातावरण के अनुकूल 
बनाने के लिए समुदाय के लोगों को भागीदार बनाया गया ताकि लोग इस पुस्तिका से उठे मुद्दों को अपने सामाजिक परिवेश से जोड़ सकें।

मैं सरकारी तथा गैर सरकारी संस्थानो को इस अभ्यास पुस्तिका को अपने क्षेत्रीय परिवेश में इस्तेमाल करने के लिए प्रोत्साहित करती हूँ। मुझे पूरा विश्वास है कि यह युवाओं के लिए प्रभावी कार्यकर्मों को बनाने में सहायक होगी। यह अभ्यास पुस्तिका, समुदाय के लोगों को भागीदार बनाने पर बल देता है तथा एक साथ बैठ कर उन महत्वपूर्ण परन्तु संवेदनशील मुद्दों पर चर्चा करने
के लिए प्रेरित करता है जिनकी चर्चा हम आमतौर पर नही करते। इस लिहाज से यह अभ्यास पुस्तिका उन लोगों के लिए काफी उपयोगी होगी जो एच. आई. वी. से बचाव तथा लैंगिक हिंसा को कम करने की दिशा में कार्य कर रहे हैं।

डा. सरोज पचौऱी क्षेत्रिय निदेशक दक्षिण तथा पूर्वी एशिया पॉपुलेशन काउंसिल, नई दिल्ली 
इस पुस्तिका का उद्देश्य युवाओं में सामाजिक लिंग, लैंगिकता तथा पौरूषता के पारंपरिक विचारों तथा मानसिकता में सकारात्मक बदलाव लाना है। यह युवाओ, परिशिक्षक, और संबंधित संस्थानों के लिए एक बहुत उपयोगी मार्गदर्शक पुस्तिका है। इसका संकलन और वर्तमान स्वरूप कई महिनों के शोध और कई लोगों के सम्मलित प्रयासों का नतीजा है।

इस अभ्यास पुस्तिका का संकलन तथा संपादन मुख्य रूप से पॉपुलेशन कॉउन्सिल, कोरो, ममता, दाउद तथा इनस्टियूटो प्रोमुण्डो द्वारा सम्मिलित रूप से किया गया।

पॉपुलेशन कॉउन्सिल : रवि कुमार वर्मा, जूली पुलरवित्ज, वैशाली शर्मा महेन्द्र तथा अजय कुमार सिंह

कोरो

ममता

: सुजाता खांडेकर, विलास सामालकर, महेन्द्र रोकड़े तथा अन्य

दाउद

: शुभ शंकर दास तथा इमतियाज खान

इनस्टियूटो प्रोमुण्डो : गैरी बारकर, मारकोश नॉसिमेंटो तथा किस्टिन रिकार्डो

हम इनस्ट्यियोटो प्रोमुण्डो के सहयोगी संस्थानों इनस्ट्युयूटो पपाईं (ब्राजील), इकोस (ECOS) तथा सालुद यॅ जेनरे (मक्सिको) को धन्यवाद देना चाहेंगे जिन्होंने 'प्रोग्राम $\mathrm{H}$ : वर्किंग विद यंग मेन सिरीज' के संपादन तथा संकलन में महत्वपूर्ण योगदान दिया।

साथ ही साथ हम उन सभी लोगों को धन्यवाद देना चाहेगें जिन्होंने इस पुस्तिका को वर्तमान स्वरूप में लाने के लिए विभिन्न चरणो में अपना बहुमूल्य योगदान दिया।

सबसे पहले हम मॅकआर्थर फाउंडेसन, एस. एस. एल. इंटरनेशनल तथा हेवलेट फाउंडेसन को धन्यवाद देना चाहेगें जिन्होने यारी दोस्ती कार्यक्रम को भारत में चलाने के लिए हमें आवश्यक आर्थिक सहयोग किया ।

हम विनिता नाथानी (प्रेरणा), प्रभा नागराज (तारशी), सुनयना वालिया (आई.सी.आर.डब्लू), वीरा मेनडॉनसा (यूनीसेफ), जमील ज़मीर एवम अंजली कपिला (आई.पी.पी.एफ) तथा सतीश कुमार सिंह (मेसवा) के अभारी है जिन्होंने इस पुस्तिका की आलोचनात्मक समीक्षा की तथा जिनके सुझावों से इस पुस्तिका में महत्वपूर्ण परिवर्तन किए जा सके।

हम पॉपुलेशन कॉउन्सिल से विजया निदादावोलू, वी. एल. थॉमस एवम अनुराग मिश्रा, श्रृष्टी संस्था के जितेन्द्र वर्मा तथा प्रेम कुमार एवं सूरज कनौजिया के भी आभारी है जिन्होने इस पुस्तिका को हिंदी में संकलित तथा टंकित करने मे अपना अथक योगदान दिया।

अंत में हम अपने प्रेरकों तथा उनके समूह के युवाओं को भी धन्यवाद देना चाहेंगे जिन्होंने चर्चा के दौरान उठे विभिन्न मुद्दों पर इस अभ्यास पुस्तिका को युवाओं के अनुरूप बनाने में बहुमूल्य योगदान दिया। 



\section{भूमिका}

पिछले कुछ सालों में ऐसे कार्यक्रम चलाये गये हैं जिनके द्वारा सामाजिक लिंग संबंधी विषमताओं में कमी आई है, साथी (स्त्री या पुरूष) के साथ व्यवहार में सकारात्मक परिवर्तन हुआ है तथा एचआईवी/यौन रोगों के बढ़ते हुए खतरे को कम किया जा सका है। इसी सन्दर्भ में पॉपुलेशन काउंसिल / होराईजन्स नई दिल्ली एवम् कोरो, (CORO), मुम्बई, द्वारा मुम्बई के झुग्गी झोपड़ियों में यारी दोस्ती नामक कार्यक्रम 2005 से चलाए जा रहे हैं। इस कार्यक्रम का मुख्य उद्देश्य युवाओं में पौरूषता तथा सामाजिक लिंग (जेन्डर) के प्रति सोच में सकारात्मक परिवर्तन लाना है, ताकि एच. आई. वी. तथा एड्स के संभावित खतरे को कम किया जा सके। इस कार्यक्रम के दो प्रमुख पहलू है पहला सामूहिक शिक्षा और दूसरा समुदाय के स्तर पर संचार अभियान। यारी दोस्ती कार्यक्रम ब्राजील में चलाये जा रहे प्रोग्राम एच से प्रेरित है एवम् उनका अनुकूलन है ।

ब्राजील में चलाये गये प्रोग्राम एच का सम्पादन इंस्टीट्यूटो प्रोमुण्डो तथा इसके सहयोगियों द्वारा किया गया है। इस कार्यक्रम का उद्देश्य निम्न आय वाले समाज के युवाओं की उन मानसिकताओं का पता लगाना था जो कि पारम्परिक रूप से मर्दानगी सम्बन्धी रूढ़वादिताओं पर प्रश्न चिन्ह लगाते रहे हैं। प्रोग्राम एच का विकास ब्राजील के विभिन्न निम्न आय वाले समाजों के युवाओं तथा किशोरों के सहयोग से किया गया है। ये युवा इस कार्यक्रम के उद्देश्यों के निर्धारण में, कार्यक्रम में प्रयुक्त की जाने वाली सामग्री के विकास तथा परीक्षण में एवं अन्य किशोरों तक सामाजिक लिंगों में आपसी समानता के सन्देश को पहुँचाने में अत्यन्त सहायक सिद्ध हुए हैं। इस कार्यक्रम को मुख्यतः दो प्रकार से संचालित किया गया। प्रथम प्रयास में, पहले से परीक्षित शिक्षण
सामग्री पर आधारित सामूहिक शेक्षणिक क्रिया-कलापों में समूह-चर्चा तथा मूक कार्टून फिल्म की सहायता से पौरुष, एचआईवी/यौन रोगों तथा हिंसा को रोकने के सम्बन्ध में जानकारी प्रदान की गयी है। यह प्रशिक्षण सत्र 20 मिनट की कार्टून फिल्म तथा प्रतिभागिता आधारित 70 अभ्यास सत्रों से मिल कर बना है। प्रत्येक अभ्यास सामाजिक लिंग तथा पाँच मुख्य विचार धाराओं पर आधारित है। द्वितीय प्रयास जीवन-कौशल की सामाजिक जनचेतना फैलाने के बारे में है, जिसमें कि संचार अभियान (कैम्पेन) द्वारा सामाजिक लिंगों में आपसी समानता तथा एचआईवी की रोकथाम जैसे सन्देशों को युवाओं /समाज तक पहुंचाने का प्रयास किया गया है।

इस कार्यक्रम के परिणामों को जानने के लिए होराइजन्स तथा इंस्टीट्यूटो प्रोमुण्डो ने एक सम्मिलित सूक्ष्म अध्ययन विधि को अपनाया। जेम स्केल (जेन्डर इक्यूटेबिल मेन स्केल) के द्वारा शोधकर्ताओं ने यह जानने का प्रयास किया कि युवाओं में सामाजिक लिंग सम्बन्धी मानसिकताओं में कुछ परिवर्तन आया है या नहीं। (पुलेरविट्ज, बार्कर, तथा सेगुण्डो, 2004) इस अध्यन में पाया गया कि कार्यक्रम में सहभागिता के पश्चात् (प्रारम्भ से 6 माह पश्चात्) युवाओं में सामाजिक लिंग सम्बन्धी मानसिकता में सांकेतिक रूप से काफी बड़ा बदलाव आया है, इसके अतिरिक्त समूह में जीवन-कौशल तथा संचार अभियान के फलस्वरूप यौन संचारित संक्रमणों की दर में 45 प्रतिशत तक की कमी देखी गयी, एक ही साथी के साथ यौन सम्बन्धों में कंडोम के इस्तेमाल करने की प्रवृत्ति में भी बढ़ोत्तरी देखी गयी। एक वर्ष बाद भी दोबारा अध्ययन करने पर इन सकारात्मक परिवर्तनों को देखा गया - कहीं-कहीं पर पहले से ज्यादा परिर्वतन देखा गया। नीति निर्धारक, युवाओं में सामाजिक लिंग 
सम्बन्धी विषमताओं तथा एचआईवी की रोकथाम सम्बन्धी नीतियों को बनाने में उपरोक्त परीक्षणों का प्रयोग कर सकते हैं। इन परिणामों के आधार पर यह निष्कर्ष निकलता है कि युवाओं के साथ इस तरह के हस्तक्षेपिक प्रयास अधिक कारगर सिद्ध होते हैं, और उनमें सामाजिक लिंग सम्बन्धी समानताओं को विकसित किया जा सकता है तथा युवाओं में एचआईवी के खतरे की स्थिति में कमी लाई जा सकती है। भारत तथा दूसरे अन्य देशों में भी इस तरह के हस्तक्षेपिक प्रयासों की शुरूआत की गई है। यह पुस्तिका/मैनुअल ब्राजील में चलाये गये 'प्रोग्राम एच - वर्किंग विथ मेन सिरीज' नामक पाठ्यक्रम पर आधारित है। इसके अलावा इसमें युवाओं के साथ काम करने के सम्बन्ध में प्रस्तावना, भारतीय संस्कृति में इसकी उपयोगिता के बारे में बताया गया है।

\section{1. किशोरों तथा युवा पुरूषों के कार्यकमों की प्रासंगिकता}

सम्पूर्ण विश्व में अधिकांश वयस्क तथा किशोर पुरुषों की सोच एवं व्यवहार - उनमें तथा उनके साथियों में एचआईवी के खतरे को बढ़ाता है। कुछ भागों में महिलाओं में एचआईवी का संक्रमण तेजी के साथ फैल रहा है परन्तु विश्व में अभी भी एचआईवी संक्रमित व्यक्तियों में पुरुषों की संख्या अधिक है। यूएनएड्स, (2004) के अनुसार, सन् 2003 के अन्त तक 18.7 लाख पुरुष तथा 17 लाख महिलाओं के एचआईवी/एड्स से संक्रमित होने की सम्भावना व्यक्त की गई थी। ग्रीन, (1997) के शोध के अनुसार इस संक्रमण से किशोरों को सबसे ज्यादा खतरा है। विश्व में एचआईवी तथा एड्स से संक्रमित प्रत्येक चार में से एक व्यक्ति 25 वर्ष से कम आयु का है। तथा चूँकि युवा या वयस्क दोनों ही सामान्यतः एक से अधिक महिलाओं के साथ सम्बन्ध रखते हैं - एचआईवी का संक्रमण पुरुष से महिला में तथा पुरुष से पुरुष में, महिला से पुरुष की तुलना में आसानी से फैलता है इसलिए किसी एचआईवी संक्रमित पुरुष द्वारा एचआईवी संक्रमित महिला की तुलना में दूसरे व्यक्तियों को संक्रमित करने की सम्भावना बढ़ जाती है। यूएनएड्स के एक अधिकारी के अनुसार "एचआईवी महामारी का कारण पुरुष है.... हो सकता है कि विश्व में एचआईवी तथा एड्स का प्रभाव महिलाओं पर अधिक होता हो, फिर भी
इस विषाणु का प्रसार कुछ सीमित पुरुषों के यौन व्यवहार तथा नशे की आदत पर आधारित होता है" (फोरमेन, 1999)। यूएनएड्स ने सन् 2000 से लेकर 2001 तक पुरुषों तथा लड़कों के लिए सम्पूर्ण विश्व में एक एड्स अभियान चलाया था जिसमें इस बात को मान्यता मिली कि अधिकांश पुरुषों का यौनाचार उनके लिए तथा उनके साथी के लिए खतरनाक होता है तथा पुरुषों को इस पर ध्यान देना चाहिए कि वे तथा उनके साथी एचआईवी तथा एड्स की रोकथाम में सहायक हों एवं एड्स के साथ जी रहे व्यक्तियों को सहायता प्रदान करें।

इसके अतिरिक्त युवाओं को इस कार्यक्रम में जोड़ने का एक कारण यह भी है कि युवाओं में एचआईवी तथा एड्स का खतरा कहीं ज्यादा होता है तथा जिन पर कि पूरी तरह से अभी तक ध्यान नहीं दिया गया है। अनुसंधानों के द्वारा हमें यह समझने में आसानी होती है कि समाज में पुरुष या महिला होने का क्या तात्पर्य होता है। अध्ययनों के द्वारा पता चलता है कि असुरक्षित यौन सम्बन्धों के द्वारा लड़के किस तरह से अपने आपको सम्पूर्ण पुरुष मानने लगते हैं, लड़के अपने दोस्तों से किस प्रकार महिलाओं के प्रति हिंसात्मक रुख अपनाने के बारे में सीखते हैं तथा किस प्रकार पुरुषों को अपनी भावनाओं को व्यक्त करने तथा स्वास्थ्य सम्बन्धी सेवाओं को प्राप्त करने से रोका जाता है। लड़कों तथा पुरुषों के व्यवहार का आधार — चाहे यह साथी के साथ कंडोम के इस्तेमाल की चर्चा के बारे में हो, अपने बच्चों के पालन-पोषण के बारे में हो या फिर यह साथी के साथ हिंसा करने के बारे में हो - उनका पारिवारिक तथा सामाजिक माहौल होता है। हम अधिकांशतः पुरुषों के व्यवहार को प्राकृतिक ही मानते हैं क्योंकि हमें लगता है कि सभी पुरुष ऐसे ही होते हैं। पुरूषों में हिंसा, नशाखोरी, आत्महत्या एवं महिलाओं के प्रति अपमानजनक व्यवहार, आदि का आधार समाज तथा परिवार में लड़के लड़कियों के पालन-पोषण पर निर्भर करता है। समाज में लड़कों के पालन-पोषण तथा उनकी उपयोगिता के बारे में परिवर्तन लाना आसान नहीं है लेकिन यह आवश्यक है कि पौरुष से जुड़ी हुई कुछ पारम्परिक मूल्यों के प्रति आलोचनात्मक चिंतन पैदा किया जाए।

कोरो तथा होराइजन्स / पापुलेशन काउंसिल के द्वारा मुम्बई की शहरी झुग्गी-बस्तियों में किशोरों पर किये गये अध्ययन के अनुसार "असली मर्द" वही है जो शारीरिक 
रूप से आकर्षक हो, तथा यौन रूप से शक्तिशाली हो। इसके अलावा असली मर्द को महिलाओं पर नियंत्रण करना आना चाहिए तथा उसे हिंसात्मक व्यवहार करना भी आना चाहिए। इन युवाओं की राय में युवतियां भी ऐसे ही मर्दों को पसन्द करती हैं। युवाओं ने इस बात पर जोर दिया कि ना केवल मर्दानगी का होना जरूरी है, बल्कि पौरुष मर्दानगी को साबित करना भी आवश्यक है तथा उन्होंने महिलाओं के साथ छेड़ छाड़ एवं जोर जबरदस्ती, असुरक्षित यौन सम्बन्ध, शराब एवं नशीली दवाओं के प्रयोग जैसी बातों को पौरुष के साथ जोड़ा।

एचआईवी तथा एड्स तथा युवाओं के बारे में चर्चा करते समय पुरुषों के साथ सम्बन्ध बनाने वाले पुरुष (एमएसएम MSM) जैसे सामान्यतः अछूते विषयों पर भी चर्चा की जानी चाहिए। पुरुषों द्वारा आपस में यौन-क्रिया की चर्चा के दौरान अधिकांशतः इस तरह की साधारण मान्यताएं सामने आती हैं कि वे पुरुष जो जनखे/नामर्द होते हैं तथा जो समलैंगिक होते हैं, वही पुरुषों के साथ यौन सम्बन्ध बनाते हैं। इस कारण से ही यूएनएड्स तथा डब्ल्यूएचओ मुख्यतः समलैंगिक पुरुषों के स्थान पर 'मैन हू हैव सेक्स विथ मैन (एमएसएम MSM) अथवा 'समलिंगी के साथ यौन सम्बन्ध जैसे विशेषणों का प्रयोग करते हैं। पुरुषों द्वारा पुरुषों के साथ सम्बन्ध बनाने के बारे में पूर्वाग्रहों से ग्रसित होने के कारण हीनता की भावना, सामाजिक बेड़ियों तथा भ्रान्तियों के कारण समलैंगिक पुरुषों को एचआईवी की रोकथाम में एक अवरोधक के रूप में देखा जाता है। इस प्रकार एचआईवी की रोकथाम के कार्यक्रमों का युवाओं पर केन्द्रित होना इस बीमारी के प्रसार को काफी हद तक सीमित कर सकता है चाहे वह युवाओं के द्वारा वर्तमान में की जाने वाली अथवा भविष्य में की जाने वाली यौन क्रिया-कलापों के सम्बन्ध में हों।

इस प्रकार कुछ कार्यक्रम सामाजिक लिंग पर आधारित कुछ ऐसे प्रश्नों का उत्तर ढूंढ़ते हैं जिससे कि सामाजिक लिंगों में आपसी समानता तथा दैनिक जीवन में सामाजिक लिंग आधारित विचारों को बढ़ावा दिया जा सके। किशोरवय लड़कों तथा युवाओं को दी जाने वाली शिक्षा को सामाजिक लिंग आधारित शिक्षा बनाने का क्या तात्पर्य है? सामाजिक लिंग - अर्थात् सेक्स या लिंग - का तात्पर्य यह है कि समाज में पुरुष या महिला होने के नाते समाज हमसे क्या अपेक्षाऐं रखता है; इन अपेक्षाओं के चलते हमारी सामाजिक स्थिति क्या है, हम किस तरह का व्यवहार
करते हैं तथा हम किस तरह के वस्त्र पहनते हैं सभी यह लिंग-भेद को प्रतिपादित करने, उसे मान्यता प्रदान करने तथा इसके बारे में शिक्षा देने के एक सामाजिक तरीके के रूप में देखा जा सकता है। युवाओं को शिक्षित करते समय लिंग आधारित शिक्षा देने के दो प्रमुख कारण हैं :

a. लड़कों को अपने सामाजिक तथा सांस्कृतिक वातावरण में व्याप्त सामाजिक लिंग सम्बन्धी विषमताओं के बारे में ऐसी चर्चा में शामिल करना जिसमें कुछ इस तरह के ज्वलन्त विषयों को शामिल किया जाए जिनमें कि, महिलाओं को सामाजिक लिंग सम्बन्धी भेद-भाव के कारण बच्चों को पालने, घरेलू काम करने, तथा यौन एवं प्रजनन स्वास्थ्य के लिए उत्तरदायी मानने जैसे कार्यों के प्रति जिम्मेदार ठहराया जाता है।

b. कुछ ऐसी सामाजिक मान्यताओं का पुनरावलोकन करना जिनमें कि लड़कों के स्वास्थ्य तथा विकास के सम्बन्ध में बताया गया हो अर्थात् लड़कों में इस तरह की चर्चा की शुरूआत करना जिससे कि वे नशीली दवाओं / शराब तथा असुरक्षित यौन व्यवहार से होने वाले नुकसान को समझ सकें।

\section{2. युवाओं को ही युवाओं के साथियों के रूप में एक अवरोधक मानना}

लड़कों तथा युवाओं के बारे में अधिकांश चर्चाएं उनकी समस्याओं पर ही आधारित होती हैं जैसे कि प्रजनन तथा यौन शिक्षा में उनकी सक्रिय भूमिका का अभाव अथवा कई बार उनका हिंसक व्यवहार। पिछले कुछ अध्ययनो के अनुभवों से लड़को को स्वास्थ्य सम्बन्धी प्रयासों में एक अवरोधक माना गया है। इस पुस्तिका/मैनुअल की शुरूआत में ही इन किशोरों को एक सक्रिय तथा मजबूत सहारे के रूप में मान्यता प्रदान की गयी है न कि एक अवरोधक के रूप में। लड़के चाहे वे कभी-कभी हिंसक हो जाते हों अथवा अपने साथी को सम्मान न देते हों उनमें इस तरह की क्षमता होती है कि वे एक समझदार और जिम्मेदार साथी के रूप में आपसी रिश्तों में सम्मानपूर्वक विभिन्न मुद्दों पर बातचीत कर सकते हैं, अपने बच्चों के देखभाल में जिम्मेदारी और अपने साथी के साथ आजीवन 


\section{बाक्स 1 : एचआईवी एवं युवा पुरूष}

i. युवाओं का असुरक्षित व्यवहार महिलाओं के लिए खतरनाक होता है : अधिकांशतः महिलाओं की तुलना में पुरुषों द्वारा एक से अधिक व्यक्तियों के साथ सम्भोग की प्रवृत्ति अधिक पायी जाती है। एचआईवी का संक्रमण पुरुषों द्वारा महिलाओं में, महिलाओं से पुरुषों की तुलना में आसानी से फैलता है। एचआईवी संक्रमित महिला की तुलना में एचआईवी संक्रमित पुरुष आसानी से दूसरों को संक्रमित कर सकता है। एचआईवी की रोकथाम के कार्यक्रमों में अधिक से अधिक पुरुषों को जोड़ने के द्वारा महिलाओं के संक्रमित होने के खतरे को कम किया जा सकता है।

ii. युवाओं का असुरक्षित यौन व्यवहार उनके लिए भी खतरनाक होता है : भले ही महिलाओं की एचआईवी संक्रमित होने की दर अधिक हो फिर भी संक्रमित पुरुषों की संख्या अधिक है। युवतियों की तुलना में युवक बहुत कम स्वास्थ्य सेवाओं का प्रयोग करते हैं। युवक विषम परिस्थितियों में - जैसे कि एड्स के साथ जीने में - युवतियों की तुलना में कम ही ठीक रह पाते हैं। विश्व में महिलाओं की तुलना में अधिकांशतः पुरुषों द्वारा शराब एवं नशीली दवाओं का प्रयोग एचआईवी के खतरे को बढ़ाने में सहायक होता है।

iii. पुरुषों द्वारा किशोरों के साथ यौन सम्बन्ध जैसे मुद्दों पर अधिकांशतः चर्चा ही नहीं की जाती है : विश्व के विभिन्न भागों में किये गये सर्वेक्षणों के आधार पर यह निष्कर्ष निकल कर सामने आता है कि, शामिल किये गये सभी पुरुषों में से 1 से 16 प्रतिशत पुरुषों ने कभी न कभी दूसरे पुरुष के साथ यौन सम्बन्ध बनाने के बारे में माना है, चाहे वे समलैंगिक हों, उभयलिंगी हों, अथवा इतरलिंगी। एमएसएम के प्रति सामाजिक वैमनष्य तथा भ्रान्तियां एचआईवी की रोकथाम में अवरोधक हैं।

iv. विकास-क्रम के रूप में देखने पर पता चलता है कि किशोरावस्था के दौरान ही अर्न्तरंग सम्बन्धों को स्थापित करने के तरीकों के बारे में प्रयास शुरू हो जाते हैं : महिलाओं को यौन तृप्ति के एक साधन के रूप में देखना, प्रजनन स्वास्थ्य से जुड़े सभी सवालों को महिलाओं से जोड़ना, यौन सम्बन्धों में जबरदस्ती करना तथा सेक्स को एक कार्य क्षमता के रूप में देखना, आदि किशोरावस्था से ही शुरू हो जाते हैं (कभी-कभी इससे पहले भी) तथा वयस्क होने पर भी ऐसी ही मनोस्थिति बनी रहती है। समय के साथ-साथ अर्त्तरंग सम्बन्धों में साथी के साथ किये जाने वाले व्यवहार में परिवर्तन होता रहता है। अतः किशोरावस्था में इस बारे में सही जानकारी देने के द्वारा भविष्य में पुरुषों द्वारा महिलाओं के साथ किये जाने वाले व्यवहार में सकारात्मक परिवर्तन लाया जा सकता है।

v. पुरुषों को परिवार में एचआईवी के साथ जी रहे व्यक्ति की देखभाल करने में एक महत्वपूर्ण किरदार निभाना चाहिए तथा इस बारे में भी ध्यान देना चाहिए कि उनका यौनाचरण उनके अपने बच्चों को किस प्रकार प्रभावित कर सकता है : इतनी अधिक संख्या में पुरुषों के एचआईवी तथा एड्स की चपेट में आ जाने से लाखों महिलाओं तथा बच्चों को आर्थिक संकट का सामना करना पड़ रहा है। एचआईवी के साथ जी रहे व्यक्ति की देखभाल अधिकांशतः महिलाओं द्वारा ही की जाती है। युवा तथा वयस्क पुरुष दोनों को ही इस तरह की देखभाल करने के लिए प्रेरित किया जाना चाहिए। वे युवा जो कि पिता भी हैं उन्हें इस बात का ध्यान रखना चाहिए कि उनका असुरक्षित यौन व्यवहार या तो उनके बच्चों को एचआईवी संक्रमित बना सकता है अथवा उन्हें अनाथ भी कर सकता है।

vi. एचआईवी तथा एड्स के कार्यकमों में युवाओं की भागीदारी एक कार्यक्रमिक एवं आर्थिक कारण भी है : लड़के तथा किशोर अधिकांशतः वयस्क पुरुषों की तुलना में किसी भी प्रकार की शिक्षा अथवा सामूहिक क्रिया-कलापों में भागीदारी करने के लिए आसानी से तैयार हो जाते हैं। 
शान्ति एवं सौहार्दपूर्ण जीवन बिना किसी हिंसा के बिता सकते हैं।

शिक्षक, अभिभावक, अध्यापक तथा स्वास्थ्य कार्यकर्ता होने के नाते हमारे व्यक्तिगत अनुभवों तथा विभिन्न अनुसंधानों से प्राप्त परिणामों के आधार पर यह कहा जा सकता है कि लड़के हमारी आशाओं के अनुरूप व्यवहार करते हैं। यदि हम लड़कों से यह चाहते हैं कि उनमें हिंसक प्रवृत्ति बनी रहे, वह अपनी संतानों के प्रति अपने दायित्वों से विमुख रहें तथा प्रजनन एवं यौन स्वास्थ्य से जुड़े मुद्दों से दूरी बनाकर रखें तो हम स्वतः ही उनके लिए खतरनाक परिस्थितियों का निर्माण करते हैं तथा आने वाले समय में कुल संक्रमितों की संख्या के संबंध में की गयी भविष्यवाणियों के सार्थक होने के लिए एक मजबूत आधार तैयार करते हैं। इस पुस्तिका/मैनुअल का आधार ही यह है कि लड़कों तथा युवाओं के साथ दोस्ताना व्यवहार किया जाना चाहिए। कुछ युवा कई बार हिंसात्मक तथा गैर जिम्मेदाराना व्यवहार करते हैं। हमारा उद्देश्य उनके व्यवहार की अनदेखी करना नहीं है अपितु हम यह मानते हैं कि, यह आवश्यक है कि हम इस तरह से शुरूआत करें कि, अधिकांश युवा सकारात्मक व्यवहार करते हैं तथा अन्य युवा भी उनका अनुसरण करेंगे ऐसी आशा करते हैं।

\section{3. पुस्तिका के संदर्भ में}

यह पुस्तिका यारी दोस्ती कार्यक्रम के सामूहिक शिक्षा के अभ्यास सत्रों का संकलन हैं। ये अभ्यास सत्र ब्राजील में प्रोग्राम $\mathrm{H}$ के दौरान युवाओं के साथ चलाये गये अभ्यास सत्रों पर आधारित है। भारतीय सामाज के अनुकूल बनाने के लिए इन अभ्यास सत्रों के स्वरूप में थोड़ा सा परिवर्तन किया गया है।

इस पुस्तिका में 29 अभ्यास सत्र हैं, जिन्हें निम्नलिखित चार उपखण्डो में बांटा गया है।

1. सामाजिक लिंग (Gender)

2. लैंगिकता तथा प्रजनन स्वास्थ्य (Sexuality and Reproductive Health)

3. हिंसा (Vioence)

4. एच. आई. वी. तथा एड्स के साथ जीना तथा इसकी रोकथाम। (Living with HIV \& AIDS and prevention)
प्रत्येक उपखण्ड में कई अभ्यास दिये गये है जो कि 45 मिनट से दो घंटे की अवधि तक के हैं। इन अभ्यासो के द्वारा सामाजिक लिंग तथा इनसे जुड़े पहलुओं को समझना है, मसलन सामाजिक लिंग क्या हैं, इसका निर्माण कैसे होता है और कैसे इसका प्रभाव लोगों के लैंगिकता तथा प्रजनन स्वास्थ पर होता है। सामाजिक लिंग का बहुत ही गहरा रिश्ता लोगों के हिंसक रवैये से खास करके औरतों पर होने वाली हिंसा से है। इन सभी पहलुओं को सामाजिक लिंग से जोड़ने का यह मकसद भी है ताकि युवाओं में इन विषयों पर एक आलोचनात्मक चिंतन पैदा किया जा सके। आशा की जाती है कि सामूहिक स्तर पर किए जाने वाले चिंतन नये समाजिक मूल्यों के निर्माण में सहायक होंगे। इन अभ्यासों के द्वारा यह भी प्रयास किया गया है कि लोंगों की मानसिकता सामाज में एच, आई, वी तथा एड्स के साथ जी रहे लोगो के प्रति बदला जा सके तथा इनके खतरे को कम किया जा सके।

प्रथम उपखण्ड में 8 अभ्यास है। इन अभ्यासों के द्वारा युवाओं में पौरूषता के साकारात्मक पहलुओं से अवगत कराना तथा यह बतलाना है कि स्त्रियों और पुरूषों के प्रति लोगों के नजरिये में समरूपता होनी चाहिए।

इस पुस्तिका के दूसरे उपखण्ड में लैंगिकता तथा प्रजनन स्वास्थ्य से जुड़ी मानसिकताओं में साकारत्मक बदलाव लाने का प्रयास किया गया है। इस भाग में 8 अभ्यास हैं जिनके द्वारा विशेष रूप से यह समझाने का प्रयास किया गया है कि यौन संबंधो एवं प्रजनन स्वास्थ्य में पुरूषो की जिम्मेदार भागीदारी एक स्वस्थ पारिवारिक जीवन के लिए अति महत्वपूर्ण है। स्त्री और पुरूषों के प्रजनन अंगों के बारे में सचित्र विवरण दिया गया है ताकि युवाओं को अपने तथा स्त्रीयों के शरीर के बारे में वैज्ञानिक एवं अर्थपूर्ण जानकारी हो।

तीसरे उपखण्ड में 6 अभ्यास सत्र हैं, इनमें लड़के और लड़कियों के प्रति होने वाले हिंसा के बारे में समझने का प्रयास किया गया है। इन अभ्यासों में विशेष रूप से यौन संबंधों तथा पति-पत्नि के बीच होने वालें हिंसा को सामने लाने का प्रयास किया गया है। हर अभ्यास के अंत में यह समझाने का प्रयत्न किया गया कि लोगों को अपने साथी की इच्छाओं और उनकी सोच का सम्मान करना चाहिए। 
एच. आई. वी. तथा एड्स से संक्कमित लोगों के प्रति लोगों की मानसिकता में सार्थक बदलाव लाने का प्रयास भाग-4 में किया गया है। इस उपखण्ड में 7 अभ्यास सत्र है, इनके द्वारा युवाओ को यह बताने की कोशिश की गयी है कि एच. आई. वी. से संकमित लोगों को घृणा की नही बल्कि प्यार और सहानुभुति की जरूरत होती है। साथ ही साथ इस भाग में एच. आई. वी. से बचाव के बारे में भी चर्चा की गयी है।

हांलाकि यह पुस्तिका 15-24 वर्ष के युवाओं को ध्यान में रख कर बनायी गयी है, पर इसका प्रयोग इस आयु वर्ग से ऊपर के पुरूषों के कार्यकमों में भी इस्तेमाल किया जा सकता है।

आशा की जाती है की यह संकलन भारत में युवाओं के साथ चलाए जा रहे कार्यक्रमों में सहायक सिद्ध होगी।

\section{सुझाव}

यह कार्यक्रम किसी समूह के साथ करना फायदेमंद होगा, जैसे केवल लड़को का समूह या फिर लड़के. लड़कियों का मिश्रित समूह। हमारा मानना है कि दोनो प्रकार के समूहों के साथ काम करना लाभप्रद होता है। वे संस्थाएं जो कि किशोरों तथा युवाओं के साथ कार्य कर रहे हों साथ ही साथ महिलाओं एवं पुरुषों के मिश्रित समूहों के साथ भी कार्य कर रहे हों, उनके लिए हमारा परामर्श यह है कि कभी.कभी सिर्फ पुरुषों के समूह के साथ कार्यकम करना अधिक कारगर सिद्व होता हैं। ज्यादातर लड़के तथा युवक, महिलाओं की अनुपस्थिति में अपनी भावनाओं, लैंगिकता एवं अपनी उत्तेजनाओं के बारे में खुलकर बोल पाते हैं। प्रेरक/सुविधादाता तथा दूसरे पुरुषों की उपस्थिति में वे (पुरुष/लड़के) अपनी भावनाओं को बिना किसी झिझक के आसानी से व्यक्त कर पाते हैं, जिनकी अभिव्यक्ति समाज में आमतौर पर मान्य नहीं है।

हमारे अनुभवों के अनुसार कुछ युवा चाहते हैं कि इस प्रकार के कार्यक्रमों में महिलाओं को भी शामिल किया जाना चाहिए क्योंकि उनकी उपस्थिति से चर्चा को अधिक रुचिकर बनाया जा सकता है। हालांकि कई अवसरों पर यह देखा गया है कि महिलाओं की उपस्थिति के कारण पुरुष अपनी भावनाओं को व्यक्त करने में असहज महसूस करते हैं तथा वे नहीं चाहते हैं कि
महिलाएं अर्न्तरंग सम्बन्धों के बारे में किसी प्रकार की चर्चा में भाग लें। कभी-कभी यह भी देखा गया है कि पुरुष अपनी भावनाओं को व्यक्त करने में न केवल असहज महसूस करते हैं बल्कि इसे एक स्त्रियोचित व्यवहार के रूप में देखते हैं।

इस तरह के अभ्यास के दौरान कई पुरुषों ने माना कि उन्होंने पहली बार किसी पुरुष समूह के साथ किये जाने वाले किसी भी प्रकार के क्रिया-कलाप में भाग लिया है, तथा कुछ युवकों के अनुसार शुरूआत में तो यह काफी कठिन था परन्तु जैसे-जैसे वे आगे बढ़ते गये उन्होंने पुरुषों के साथ सामूहिक अभ्यास में भाग लेने की आवश्यकता को समझना शुरू कर दिया।

इस प्रकार हमारा सुझाव यह है कि विभिन्न शैक्षिक अभ्यास सत्र जो विशेष रुप से स्वास्थ्य और सामाजिक लिंग पर आधारित हो, ऐसे सत्रो में कुछ समय युवा स्त्रियों और युवा पुरुषों को सम्मलित रूप से भाग लेने का मौका देना चाहिए। पुरुष तथा महिलाएं साथ-साथ रहते हैं, कार्य करते हैं, उनमें से कुछ युगल जोड़े विभिन्न परिवारों की संरचना करते हैं। हम मानते हैं कि शिक्षक, परिक्षक और विशेषज्ञ जो युवा लोगों के साथ काम कर रहें है, उन्हे युवा वर्ग को अपने आपसी सम्बंधो में आदर और समानता के लिए प्रोतसाहित करें।

\section{4. अभ्यासों का अनुकूलन एवं क्रियान्वयन}

भारत के युवाओं में पौरुष को लेकर फैली मान्यताओं तथा भ्रान्तियों का अध्ययन करने के लिए कोरो तथा होराइजन्स/पॉपुलेशन कांउसिल ने ब्राजिल में चलाये गए प्रोग्राम $\mathrm{H}$ को भारतीय संस्कृति के अनुकूल बना कर इसकी शुरूआत यारी-दोस्ती के नाम से की। जिसके लिए मुम्बई के तीन शहरी झुग्गी-झोपड़ियों को चुना गया। तीनों स्थानों पर सामुदायिक शैक्षणिक सत्रों को शुरू करने के लिए एक सप्ताह की एक कार्यशाला का आयोजन किया गया। इस कार्यशाला के पश्चात् दो माह की अवधि तक सामुदायिक परामर्श की व्यवस्था की गई थी जिसमें कि हमारे लोगों द्वारा भारतीय संस्कृति के परिपेक्ष्य में 20 से अधिक सामूहिक शैक्षणिक अभ्यासों का आयोजन किया गया। इन अभ्यासों में मुख्यतः एच. आई. वी./यौन रोगों का खतरा तथा इनकी रोकथाम, साथी के साथ तथा परिवार / समाज में हिंसा, लैंगिकता, 
प्रजननतंत्र एवं सामाजिक लिंग जैसे विषयों को शामिल किया गया।

इसके बाद, मुम्बई की झुग्गी-बस्तियों में रह रहे निम्न आय वर्ग के पुरुषों पर इन अभ्यासों का परीक्षण किया गया। इस कार्य के लिए कोरो ने समुदाय में रह रहे ऐसे दस युवा प्रेरकों का चयन किया जो मर्दानगी के अघ्यन से जुड़े थे, तथा जिनमें समूह संचालन की प्रतिभा थी। चयनित प्रेरक को दो हफ्ते का विशेष प्रशिक्षण दिया गया जिससे कि वे अपनी जानकारी को भली-भांति प्रयोग कर सकें तथा प्रतिभागियों को ठीक प्रकार से अपनी बात समझा सकें। प्रशिक्षण में इस बात पर विशेष बल दिया गया कि प्रेरक स्वयं कि लिंगभेद संबंधी मूल्यों का सही मूल्यांकन तथा उसकी आलोचनात्मक व्याख्या करे। दस प्रेरकों ने सुविधा अनुसार पाँच जोड़ों के रूप में कार्य करना प्रारम्भ किया तथा प्रत्येक जोड़ें ने अपने अपने समुदाय से 25-30 युवकों का समूह बनाया। इन प्रेरको ने इस प्रकार समुदाय से 126 युवाओं को चुना जो कि विभिन्न सामाजिक, धार्मिक एवं सांस्कृतिक समूहों से आये थे। पहले तो एक हफ्ते तक क्रिया-कलापों को प्रेरकों तथा सामाजिक लिंग विशेषज्ञों द्वारा सम्मलित रूप से चलाया गया। तत्पश्चात् अगले 6 महीने तक हर हफ्ते एक बार एवं कभी कभी दो बार प्रेरकों द्वारा 2 से 3 घन्टे के सत्रों का संचालन किया गया।

\section{5. पुस्तिका में दिये गये अभ्यास तथा उनका उद्देश्य}

हम आशा करते हैं तथा हमारा विश्वास है कि इन अभ्यासों में भाग लेने वालें कुछ युवकों के व्यवहार में कुछ विशेष परिस्थितियों में सकारात्मक रूप से परिवर्तन आएगा। इन परिवर्तनों की सत्यता को परखने के लिए हमें कुछ अन्य अनुसंधानों/अध्ययनों की आवश्यकता पड़ेगी तथा जिसके लिए और अधिक समय की आवश्यकता है। वर्तमान परिस्थिति में विभिन्न क्षेत्रो में परीक्षणों के आधार पर हम यह कह सकते हैं कि इस तरह के प्रयास के द्वारा युवक युवतियों की मानसिकता में काफी परिवर्तन देखा गया तथा सामाजिक लिंग सम्बन्धी सोच एवं हिंसा जैसे अन्तरंग व्यवहारों में भी स्त्री तथा पुरुष दोनों की सोच में परिवर्तन आया है।

यारी-दोस्ती नामक इस प्रयास का पुनरावलोकन करने पर हम देखते हैं कि अधिकांश युवकों ने (126 में
से 118 ने) सभी क्रिया-कलापों में सक्रिय प्रतिभागिता दिखायी। साथ ही साथ अधिकांश युवा अत्यधिक उत्साहित थे क्योंकि उन्होंने पहली बार अन्य पुरुषों के साथ इस तरह के मुद्दों पर चर्चा में भाग लिया था। चूँकि प्रतिभागी मानव शरीर, सम्भोग, एचआईवी जैसे विषयों के बारे में सही जानकारी प्राप्त करने के लिए अति उत्साहित थे, इस कारण से कई बार चर्चा के दौरान उनकी सक्रिय प्रतिभागिता के सजीव प्रमाण प्राप्त हुए। इस कार्यक्रम के दौरान, अनुसंधानकर्ताओं के मतानुसार परिवर्तन की शुरूआत रूढिवादी मान्यताओं तथा खतरनाक परिस्थितियों के निषेध से होती है तथा इन मान्यताओं में परिवर्तन आवश्यक है तथा इस तरह के व्यवहारों में परिवर्तन लाने के द्वारा युवाओं में व्याप्त खतरे को सीमित किया जा सकता है।

सामाजिक लिंगों में आपसी समानता के मापदण्डों (जेम स्केल) के आधार पर प्रशिक्षण पूर्व एवं प्रशिक्षण पश्चात् लिये गये आंकड़ों के द्वारा यह बात निकल कर सामने आयी कि अधिकांश युवकों के लिंग सम्बन्धी सोच में सकारात्मक परिवर्तन आया है। उदाहरण के लिए, ऐसे पुरुषों की संख्या जिनकी राय में पत्नी के सम्भोग से मना करने पर उसे मारना उचित है, 28 प्रतिशत से गिर कर 3 प्रतिशत पर आ गई। इसी प्रकार घरेलू निर्णयों में पुरुषों के एकाधिकार के बारे में संख्या 34 प्रतिशत से गिर कर 11 प्रतिशत तक आ गई। लड़कियों से छेड़-छाड़ करने को सही मानने जैसे विषय पर यह राय 80 प्रतिशत से गिर कर प्रशिक्षण पश्चात् 43 प्रतिशत पर आ गई। अस्थायी यौन सम्बन्धों तथा साथी के साथ सम्भोग के दौरान निरोध के इस्तेमाल की प्रवृत्ति में बढ़ोत्तरी देखी गई (वर्मा, पुलरविट्ज तथा महेन्द्रा, 2005)।

\section{6. आदर्श युवा/किशोर की परिकल्पना क्या है?}

प्रशिक्षण का उद्देश्य इन परिकल्पनाओं पर आधारित है कि हम यानी शिक्षक, माता-पिता, दोस्त, पुरुष या महिला सहभागी, युवकों से किस प्रकार की आशा रखते हैं? सामाजिक लिंग आधारित समानता, अपराध पर रोक, मानसिक स्वास्थ्य और एचआईवी तथा एड्स की रोकथाम के क्षेत्र में हो रहे कार्यों का उद्देश्य यही है कि युवकों को हम किस तरह का वातावरण प्रदान करना चाहते हैं। अंत में सबसे महत्वपूर्ण बात यह है कि युवक अपनी 
इच्छाओं को व्यक्त करें कि - वे अपने समूह के लोगो से अपने प्रति किस प्रकार का व्यवहार चाहते हैं। इन सब बातों को ध्यान में रखते हुए, प्रशिक्षण में शामिल कार्यविधियों का मुख्य उद्देश्य ऐसे युवकों का निर्माण करना है जो-

- विवाद को सुलझाने में बल का नहीं बल्कि असरदार संवाद व तर्क का इस्तेमाल करने में विश्वास रखते हों।

- दूसरे माहौल व इतर जीवन शैली से संबंधित व्यक्तियों का आदर करें तथा जो इनका आदर नहीं करते हैं उन्हें इसके लिए प्रेरित करें।

- अपने आत्मीय संबंधों में साथी को आदर प्रदान करें तथा बिना किसी उपेक्षा के समानता और आपसी सम्मान पर आधारित रिश्तों को बनाए रखने का प्रयास करें।

- उस स्थिति में जब वे उभयलैंगिक हों तो प्रजनन संबंधी, प्रजनन स्वास्थ्य व सुरक्षित यौन संबंधों से संबंधित प्रश्नों की अपने साथी के साथ चर्चा कर सकें, या बच्चा न चाहने की स्थिति में कंडोम या अन्य गर्भनिरोधक विधियों के इस्तेमाल करने के सन्दर्भ में बातचीत कर सकें।

- उस स्थिति में जब एक पुरुष अपने आप को होमोसेक्सुअल (समलैंगिक) या बाइसेक्सुअल मानता हों या ऐसे पुरुष जो दूसरे पुरुष के साथ यौन संबंध रखते हो (MSM), उन्हे भी अपने साथी के साथ सुरक्षित यौन संम्बधो के बारे में बातचीत करनी चाहिए।

- अपने साथी के साथ किसी भी प्रकार का बल प्रयोग न करें।

- ऐसी बातों पर विश्वास रखते हों कि अन्य लोगों का ख्याल रखना तथा संवेदना व्यक्त करना भी पौरूषता है तथा वे किसी का भी ख्याल रखने में सक्षम हैं जैसे कि दोस्त, संबंधियों, साथी एवं संतान इत्यादि।

- ऐसी बातों पर विश्वास रखते हों कि पुरुष नाराजगी के अलावा अन्य भावों को अभिव्यक्त कर सकता है तथा भावनात्मक मुद्दों पर साथियों अथवा स्वेच्छिक संस्थाओं से आवश्यकतानुसार प्रजनन तथा मानसिक स्वास्थ्य से जुड़े विषयों पर सहायता प्राप्त कर सकता है।
- एचआईवी पॉजीटिव व एड्स से पीड़ित व्यक्तियों के साथ-साथ अपने स्वास्थ्य का ध्यान रखने की आवश्यकता को समझने की क्षमता रखते हों।

\section{7. इन क्रिया-कलापों का इस्तेमाल कैसे कर सकते हैं?}

प्रेरकों के लिए नोट:

- पिछले अनुभवों से यह ज्ञात हुआ हैं कि कार्यविधि को पृथक रूप से इस्तेमाल करने से बेहतर है कि इसका संपूर्ण रूप में प्रयोग किया जाना चाहिए।

- चर्चां के दौरान दो प्रेरकों की उपस्थिति कारगर सिद्व होती है।

- चर्चां का वातावरण ऐसा होना चाहिए कि युवकों के साथ कार्यक्रम के संपादन के दौरान उन्हें किसी प्रकार की रोक-टोक का आभास न हो।

- चर्चां में मुक्त व स्वस्थ वातावरण बनाने की कोशिश करनी चाहिए, जहां युवकों की भाषा या व्यवहार के आधार पर किसी तरह की कोई निर्णात्मक या आलोचनात्मक टिप्पणी न की जाए।

- चर्चां के दौरान विरोध की स्थिति पैदा हो सकती है, इसलिए प्रेरक को हस्तक्षेप करना चाहिए जिससे कि प्रतिभागियों में दूसरों के विचारों के बारे में सम्मान पूर्वक देखने का नजरिया विकसित किया जा सके।इस तरह का प्रयास करना चाहिए कि चर्चां अपने उद्देश्य से भटक न सकें।

- इस बात को अवश्य याद रखना चाहिए कि किशोरावस्था में पुरुष के लिए शारीरिक संबंध बनाना हमेशा आसान नहीं होता। इसलिए जिन क्रियाओं के लिए शारीरिक संबंध जरूरी हो, उनमे व्यक्तियों को एक दूसरे की सीमाओं का आदर करना चाहिए।

- यदि प्रेरक ठीक समझे तो चर्चा के लिए दिये गये बिन्दुओं को अभ्यास के दौरान कहीं पर भी शामिल कर सकते हैं, यह जरूरी नहीं है कि इन्हें सिर्फ अभ्यास के अंत में ही इस्तेमाल किया जाए। 
यह पुस्तिका मुख्यतः युवकों के साथ सामूहिक गतिविधियों के संचालन के लिए विभिन्न अभ्यास सत्रों पर केन्द्रित है। उन अभ्यासों को विकसित करने के लिए तथा इनका परीक्षण करने के लिए 15 से 20 प्रतिभागियों के समूहों का प्रयोग किया गया है। हमारे अनुभव के आधार पर कहा जा सकता है कि इस सामग्री को यदि 15 से 20 प्रतिभागियों के छोटे समूहों के साथ प्रयोग में लाया जाए तो इसकी सार्थकता बढ़ जाती है। परन्तु यदि प्रेरक चाहे तो कुछ अभ्यासों को बड़े समूहों के साथ भी प्रयोग में ला सकते हैं। पुस्तिका में संकलित अधिकांश अभ्यास कुछ ऐसी व्यक्तिगत मान्यताओं पर आधारित हैं जिनका उद्देश्य शांतिपूर्ण, सहअस्तित्व, लैंगिकता तथा मानसिक स्वास्थ्य के बारे में सकारात्मक दृष्टिकोण के लिए प्रेरित करना है। हमारा सुझाव है कि इस तरह के कार्यक्रमों में उन्हीं प्रेरकों को भाग लेना चाहिए जो इन विषयों पर सहजता महसूस करते हों और वे तथा उनकी संस्थाएं पहले इस तरह के कार्यक्रमों का संचालन कर चुकें हों। हम जानते हैं कि इस तरह की कोशिशों की शुरूआत आसान नहीं होती है तथा इनकी सफलता और असफलता के बारे में कोई भी पूर्वानुमान नहीं लगाया जा सकता है क्योंकि हिंसा, लैंगिकता तथा एड्स, ये सारे ही विचार काफी संवेदनशील हैं। हो सकता है कि कार्यक्रम के दौरान कुछ युवक खुलकर सामने आएं तथा अपनी भावनाओं को व्यक्त करें जबकि कुछ इस बारे में कुछ बोलना ही पसन्द न करते हों। हम इस तरह की कोई भी अनुशंसा नहीं करना चाहते कि इन अभ्यासों को सिर्फ सामूहिक रूप में ही प्रयोग में लाया जा सकता है बल्कि यह प्रेरक के ऊपर निर्भर करता है कि वह कक्षा के दौरान सत्र को अधिक रुचिकर बनाने के लिए इन बातों का ध्यान रखता है या नहीं कि प्रतिभागी किस मुद्दे पर सहज है तथा किस मुद्दे पर वह असहजता महसूस कर रहा है। इस तरह के कार्यक्रमों का उद्देश्य प्रतिभागियों की प्रतिक्रियाओं को जानने के अलावा उनमें आलोचनात्मक दृष्टिकोण को बढ़ावा देना और उनके विचारों तथा व्यवहार में सकारात्मक परिवर्तन लाने के बारे में है।

इस तरह की गतिविधियों के लिए सर्वोत्तम परिस्थितिय विद्यालय खेल समूह, युवा समूह, सैन्य समूह, सामुदायिक समूह, इत्यादि। किसी क्लीनिक या स्वास्थ्य केन्द्र में आने वाले युवकों के साथ भी इस तरह के कार्यक्रमों को
चलाया जा सकता है। दूसरे शब्दों में यह आवश्यक है कि यह एक शान्त वातावरण होना चाहिए। प्रेरक तथा प्रतिभागी दोनों के पास पर्याप्त समय होना चाहिए।

इस बात का ध्यान रखा जाना चाहिए कि अधिकांश युवक बड़े होने की प्रक्रिया से गुजर रहे होते हैं। यदि हो सके तो अभ्यास के दौरान जलपान तथा हल्के शारीरिक व्यायाम की व्यवस्था करनी चाहिए।

\section{8. पुरुष या महिला प्रेरक?}

युवाओं के साथ सामूहिक गतिविधियों को किसे आरम्भ करना चाहिए? क्या केवल पुरुष को ही प्रेरक होना चाहिए? पिछले अनुभवों के आधार पर हम कह सकते हैं कि बहुत सी जगहों पर अधिकांश युवक पुरुष-प्रेरक की उपस्थिति में सहजता महसूस करते हैं तथा वे किसी ऐसे व्यक्ति को अपने आदर्श के रूप में मान्यता प्रदान करते हैं जो उनके विचारो को ध्यानपूर्वक सुनते है। फिर भी हमारे पिछले अनुभवो कें आधार पर हम कह सकते है कि प्रेरक के महिला या पुरुष होने से ज्यादा जरूरी है उसकी गुणवत्ता और उसकी योग्यता, जो समूह को जोड़ सके, उन्हें सुन सके, उन्हें प्रोत्साहित कर सके। हमने यह भी पाया है कि ये गतिविधियां और भी कारगर हैं अगर इनका इस्तेमाल प्रेरकों के जोड़े बनाकर किया जाये और जिसमें कभी-कभी महिला-पुरुष का भी जोड़ा हो। जिसका एक बड़ा फायदा यह होगा कि युवकों के सामने एक प्रत्यक्ष उदाहरण होगा कि पुरुष व महिला एक साथ बराबरी से एक-दूसरे का आदर करते हुए भी काम कर सकते हैं।

\section{9. सामग्री की उपयोगिता}

हम आशा करते हैं कि इस सामग्री का प्रयोग बृहद स्तर पर किया जायेगा। इसके पुनःमुद्रण के लिए आवश्यक रूप से पॉपुलेशन काउंसिल, कोरो तथा अन्य सहयोगी संस्थाओं से लिखित अनुमति ली जानी चाहिए। यदि आप अपनी संस्था के नाम से इस पुस्तिका को छपवाना चाहते हैं तो कृपया पॉपुलेशन काउंसिल से सम्पर्क करें। सूत्रों का हवाला देते हुए सामग्री में दी गई किसी भी जानकारी का प्रयोग किया जा सकता है। 


\section{References}

Bhatalwande, Prakash, Gangakhedkar, Raman (200), Yauvan Ki Dahliz Par, UNICEF.

Green, C. (1997). Young men: The forgotten factor in reproductive health. Washington, DC: FOCUS on Young Adults, Occasional Paper No. 1 (Unpublished draft).

Hathcher, RA, Rinehart, W, Blackburn, R, Geuer, JS and Shelton, JD. The Essentials of Contraceptive Technology. Baltimore, Johns Hopkins University School of Public Helath, Population Information Program, 1997.

HORIZONS Report (December) 2004. Involving Yong Men in HIV Prevention Programs: Operations research on gender-based approaches in Brazil, Tanzania, and India.

Instituto PROMUNDO and collaborators. 2002 Project $H$ : Working with Young Men Series.
Joint United Nations Programme on HIV/AIDS (UNAIDS) 2004. Report on the global HIV/AIDS epidemic. Geneva.

Pulewitz J, Barker G, Segundo M. 2004 "Promoting healthy relationships and HIV/STI prevention for young men: Positive findings from an intervention study in Brazil" Horizons Research Update. April.

Srivastava, Alok, Mardangi: Purushon ke liye margdarshak, a publication of Youth Alliance of AIDS Removal (YAAR), New Delhi.

UNESCO, 2006, Masculinity for Boys: Resource Guide for Peer Educators.

Verma R K, Mahendra VS, Pulerwitz J, Khandekar S, van Dam J, Flessenkaemper S, Rangaiyan G, Barker G; 2005 "From Research to action: Addressing Masculinity as a strategy to reduce HIV risk behavior: From Research to Action"; Indian Journal of Social Work (special issue); January. 

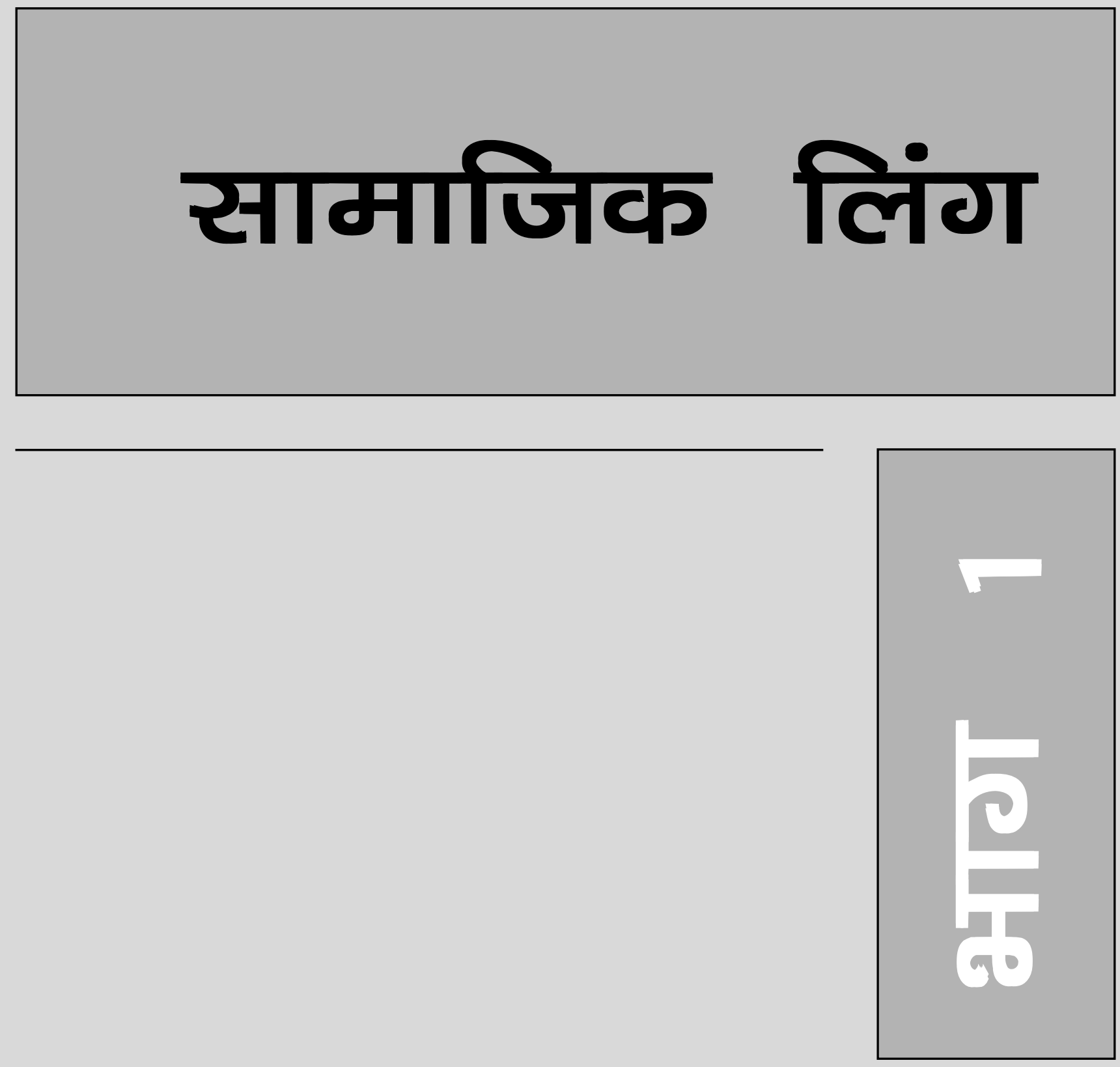



\section{अभ्यास 1.1 \\ सामाजिक लिंग}

सारांश : इस अभ्यास के अंत में हम सामाजिक लिंग की विषयवस्तु एवं उद्देश्यों को समझ सकेगें तथा यह भी जानना संभव होगा कि युवा वर्ग, स्त्रियों के बारे में क्या जानता एवं सोचता है?

उद्देश्य : लिंग से संबंधित शब्दों के अलग-अलग मतलब और भावों को समझना।

समय : 1 से डेढ़ घंटे

सामग्री : वॉल बोर्ड या दीवार, रंगीन मार्कर पेन, चॉक, कागज।

\section{विधि}

बोर्ड पर एक खड़ी लाईन खींच कर बोर्ड को दो भागों में विभाजित कर लें। पहले भाग में "पुरूष" एवं दूसरे भाग में "स्त्री" लिखें। फिर चर्चा को शुरू करने के लिए नीचे दिए गए सवालों का प्रयोग करें। हर एक जवाब को पुरूष अथवा स्त्री के लिये बने खाने में अंकित करें ताकि
उन शब्दों पर चर्चा की जा सके। इस प्रक्रिया को फ्री लिस्टिंग कहते हैं।

- पुरूष शब्द सुनकर आपकी आंखों के सामने या दिमाग में क्या आता है?

- स्त्री शब्द सुनकर आपकी आंखों के सामने या दिमाग में क्या आता है?

\begin{tabular}{|c|c|}
\hline \multicolumn{2}{|l|}{ प्रेरक को फ्री लिस्टिंग करने के लिए उदाहरण } \\
\hline $\begin{array}{l}\text { पुरूष शब्द सुनकर आपकी आंखों के सामने } \\
\text { या दिमाग में क्या आता है }\end{array}$ & $\begin{array}{l}\text { स्त्री शब्द सुनकर आपकी आंखों के सामने } \\
\text { या दिमाग में क्या आता है }\end{array}$ \\
\hline 1. बलवान & 1. सुन्दर \\
\hline 2. धोखेबाज & 2. सुशील \\
\hline 3. दारूबाज & 3. गृहणी \\
\hline 4. जुआरी & 4. वेश्या \\
\hline \multicolumn{2}{|c|}{$\begin{array}{l}\text { इन प्रश्नो के कई अन्य उत्तर हो सकते हैं जो साकारात्मक तथा नकारात्मक होंगे उसे इसी तरह कमबद्ध } \\
\text { तरीके से लिखना है। }\end{array}$} \\
\hline
\end{tabular}




\section{चर्चा के लिये सवाल}

- पुरूष होने का क्या मतलब है?

- स्त्री होने का क्या मतलब है?

- स्त्री और पुरूष में क्या भिन्नतायें हैं ...?

- स्त्री और पुरूष में क्या समानतांए हैं?

- स्त्री और पुरूष में ये फर्क किसने बनाये हैं?

- इनमें कौन से अन्तर या समानताएं, सामाजिक हैं तथा कौन सी शारीरिक?

- क्या औरतों के द्वारा किये जाने वाले घरेलू कामों की कोई कीमत नहीं होती हैं?

- औरत जो काम घर में करती है, उसी काम की कीमत मिलने पर, वही काम पुरूष बाहर करते हैं? ऐसा क्यों?

- घरों में ज्यादातर निर्णय कौन लेता है एवं क्यों?

\section{निम्न बातों पर प्रकाश डालें।}

- स्त्री और पुरूष के मापदंड समाज ने बनाए हैं।

- हमें स्त्री और पुरूष के बीच सामाजिक और शारीरिक अन्तर एवं समानता दोनों को समझना चाहिए।

- शारीरिक तौर पर स्त्री एवं पुरूष में कुछ फर्क हैं ... जो कि प्रजनन क्रिया के लिये तो आवश्यक हैं परन्तु उनसे सामाजिक अन्तर नहीं उत्पन्न होने चाहिए।

- समाज द्वारा पैदा किये गये अन्तरों को ही हम लिंग सम्बन्धी भेदभाव कहते हैं।

- कोई काम स्त्री पुरूष में जन्म से नहीं बंटा है।

- स्त्री के द्वारा किये जाने वाले घरेलू कामों की कोई कीमत न आंकना, सामाजिक रूढ़िवादता है।

\section{प्रेरक के लिए चर्चा के दौरान ध्यान देने योग्य बातें।}

- स्त्री / पुरूष शब्दों को फ्री लिस्टिंग, और चर्चा करते वक्त प्रतिभागी युवाओं की आम बोलचाल की भाषा में ही प्रयुक्त होने वाले शब्दों का ज्यादा से ज्यादा उपयोग करना चाहिए।

- फ्री लिस्टिंग करते वक्त किसी खास शब्द या विशेषण की वजह से प्रतिभागियों की भावनाओं को धार्मिक या व्यक्तिगत तौर पर ... ठेस पहुंच सकती है। इसलिये प्रेरक को ऐसे शब्दों एवं विशेषणों का सावध ानीपूर्वक उपयोग करना चाहिए।

- प्रत्येक प्रतिभागी को चर्चा में शामिल करने की कोशिश करें।

- इस प्रक्रिया में दो प्रेरकों का होना जरूरी है, एक बातचीत करने के लिये और दूसरा मुख्य बातों को लिखने के लिए। 
सारांश : पिछले अभ्यास की तरह ही इस अभ्यास द्वारा यह जानना संभव होगा कि युवा वर्ग लैगिंकता एवं प्रजनन के बारे में क्या सोचता-समझता है।

उद्देश्य : लैगिंकता और प्रजननता से संबंधित शब्दों के विविध अर्थों और व्याख्याओं को समझाना तथा प्रजनन स्वास्थ्य में पुरूषों की भागीदारी के महत्व को समझना।

समय : डेढ़ से दो घंटे।

सामग्री : वॉल बोर्ड या दीवार, कलर मार्कर।

विधि

- लैगिंकता और प्रजनन इन शब्दों को लेकर अभ्यास 1.1 की भांति ही बोर्ड पर फ्री लिस्टिंग करवाएं।

- प्रतिभागियों से पूछें कि लैंगिकता शब्द सुनकर वे क्या महसूस करते हैं? या उन के दिमाग में क्या आता है? उनके जवाब बोर्ड पर लिखकर, शब्दों की सूची बनाऐं।

- इसी तरह से प्रजनन शब्द की फ्री लिस्टिंग कराएं।

\section{चर्चा के लिए सवाल}

- लैंगिकता का क्या मतलब है?

- क्या स्त्री-पुरूष दोनों की लैगिंकता अलग-अलग होती हैं? दोनों में क्या फर्क है?

- पुरूष अपनी प्रेमभावना कैसे व्यक्त करता है? एवं स्त्री अपनी प्रेमभावना कैसे व्यक्त करती है? दोनों की अभिव्यक्ति में अन्तर क्यों है?

- प्रजनन में पुरूषों की क्या भूमिका होती है?

\section{सारांश}

अभ्यास के अन्त में प्रतिभागियों की मदद लें तथा निम्नलिखित बातों पर जोर दे।

- समाज में स्त्री और पुरूष होने का मतलब।

- लैंगिकता, मानव जीवन का समाजिक एवं मनोवैज्ञानिक पहलू है, तथा इसको जैविकीय कारणों से निर्धारित नहीं किया जा सकता है।

- याद रहे, आपसी रिश्ते हमेशा रहते हैं और इनकी भी अपनी एक मर्यादा होती है, जैसे कि - यौन संबंध में कंडोम इस्तेमाल की चर्चा करते वक्त आपसी रिश्तों में अधिकार होता है। सुरक्षित यौन संबंधों के बारे में स्त्रियों के अधिकार के बारे में चर्चा करना उचित होगा। आमतौर पर स्त्रियां सेक्स कब और कहां करना है इस बारे में बात नहीं कर सकती हैं। इस प्रकार के आपसी रिश्तों में अधिकार, आमतौर पर झूठ-मूठ की कहांनियों या लंबे समय से चली आ रही पंरपराओं पर निर्भर होता है। जैसे कि - मर्द सेक्स के लिये हमेशा तैयार रहता है और स्त्री को हमेशा नियंत्रण 
में रहना चाहिये। स्त्री को हमेशा सेक्स के लिये मर्द का ऋणी होना चाहिये। इसी प्रकार से औरत हमेशा मर्दों पर निर्भर होती है और मर्द औरत को कभी भी, कहीं पर भी सेक्स करने पर मजबूर कर सकते हैं। ऐसे अधिकारों का दुरूपयोग
समलैंगिक संबंधों में भी दिखाई देता है। ऐसे अधिकारों का मन चाहा प्रयोग जोखिम भरे यौन व्यवहारों के रूप में दिखाई देता है। जिसके कारण यौनरोग या एचआईवी होने की संभावना ज्यादा होती है।

\section{ध्यान रहे}

लैंगिकता पूर्णरूप से एक भावनात्मक अनुभूति हैं। यह न सिर्फ सेक्स बल्कि हमारे दिमाग और शरीर का संयुक्त रूप से उपज हैं। हर इंसान की लैंगिकता अलग अलग होती हैं। यह प्राकृतिक है, फिर भी यह हमारे संस्कार, व्यवहार, शारीरिक बनावट, सोच, भावनाऐं, व्यक्तित्व, धर्म तथा हमारे सामाजिक वातावरण पर निर्भर करता है।

प्रजनन पति पत्नि द्वारा संभोग करने से बच्चे के जन्म होने तक की अवस्था को कहते हैं।

\section{अधिक जानकारी के लिये ...}

\begin{tabular}{llll}
\hline अनु.क्र. & जानकारी के लिये किताबें & लेखक & संस्था \\
\hline 1. & ऐमरजिंग लीडरशिप & श्रीमती सुजाता खांडेकर & कोरो, मुबंई \\
2. & स्टेपिंग स्टोन & ऐक्शन ऐड इन्टरनेशनल & ऐक्शन ऐड इन्टरनेशनल \\
3. & यह जेंडर क्या है? & कमला भसीन & जागेश्बरी 2000 \\
4. & मर्दानगी & अलोक श्रीवास्तव & यार \\
5. & निरामय कामजीवन & डा. विठ्ठल प्रभू & मुम्बई \\
6. & यौवन की दहलीज पर & युनिसेफ & युनिसेफ \\
7. & लाल किताब & शालिनी & तारशी 1999 \\
8. & नीली किताब & शालिनी & तारशी 1999 \\
9. & आमच्या शरीरावर आमचा हक्क & मनिशा गुप्ते & सेहत \\
\hline
\end{tabular}


सारांश : इस अभ्यास के द्वारा हमें यह पता लगता है कि, लोगों को ठप्पा लगाना उचित नहीं है क्योंकि ऐसा करने से उन लोगों की क्षमता में कमी आती है तथा वह किसी बात का ठप्पा लग जाने से अपनी क्षमता का उचित प्रयोग नहीं कर पाते हैं।

समय : 2 घंटे।

सामग्री : कार्ड पेपर जिनका प्रयोग लेबल बनाने के लिए हो सके। स्केच पेन एवं लेबल चिपकाने के लिए टेप।

विधि

- प्रतिभागियों को इस सत्र की प्रक्रिया में लाकर, सत्र की गंभीरता बनाए रखने के लिए उन्हें एक गोल घेरें में बैठने को कहें तथा उनसे कहें कि उन्हें बच्चों के एक कार्यक्रम के लिए काम करना है।

- कागजों पर लिखे कुछ लेबल जैसे कि "वैश्या", "समलैंगिक", "डॉक्टर", "हिजड़ा", "गुण्डा/ भाई", "गृहणी", "नेता", "चोर", "झूठा", "गरीब", "अमीर", "अफसर" आदि। प्रतिभागियों की पीठ पर इस प्रकार चिपका दें, ताकि व्यक्ति स्वयं का तो लेबल न देख सके परन्तु दूसरों का देख सकता हो।

- सदस्यों से कहें कि वे एक-दूसरे से बिना बात किये समूह के सदस्य के पीछे लगाये हुए ठप्पे के अनुसार उससे उसी तरह का बर्ताव करें।

- इस प्रक्रिया के लिए दस मिनट का समय दें।

- प्रतिभागियों से कहें कि वे अपनी पीठ पर लगे ठप्पे को समूह से मिली प्रतिक्रिया के अनुसार पहचानने का प्रयास करें और उन्होंने क्या महसूस किया, इस पर विस्तार से चर्चा करें।

\section{बातचीत के मुद्दे : प्रतिभागियों से पूछें कि :}

- इस सत्र में क्या हुआ था? तथा प्रतिभागी युवाओं ने क्या महससू किया?

- इस समूह में हर एक व्यक्ति का जो स्वभाव सामने आया है, उससे सत्र को चलाने में मदद मिली या परेशानी हुई? इस सत्र का हमारे जीवन से कोई संबंध है? अथवा नहीं?

- गलत नामों के ठप्पे लगाने से लोगों के आपसी संबंधों पर क्या असर होता है? तथा, वास्तविक जीवन में हम इस तरह की घटनाओं को कैसे बढ़ावा देते हैं?

- सकारात्मक और नकारात्मक ठप्पों और उसके परिणामों पर भी चर्चा करें और ठप्पा लगने से होने वाले फायदे और नुकसान के बारे में भी विचार करें।

- ठप्पे ज्यादातर किस पर लगाये जाते हैं? सत्री या पुरूष पर?

- स्त्रियों के संबंध में आने वाले ठप्पों का लिंग की संकल्पना से किस तरह का संबंध है। इस पर चर्चा करें - जैसे, चालू लड़की, इत्यादि। 


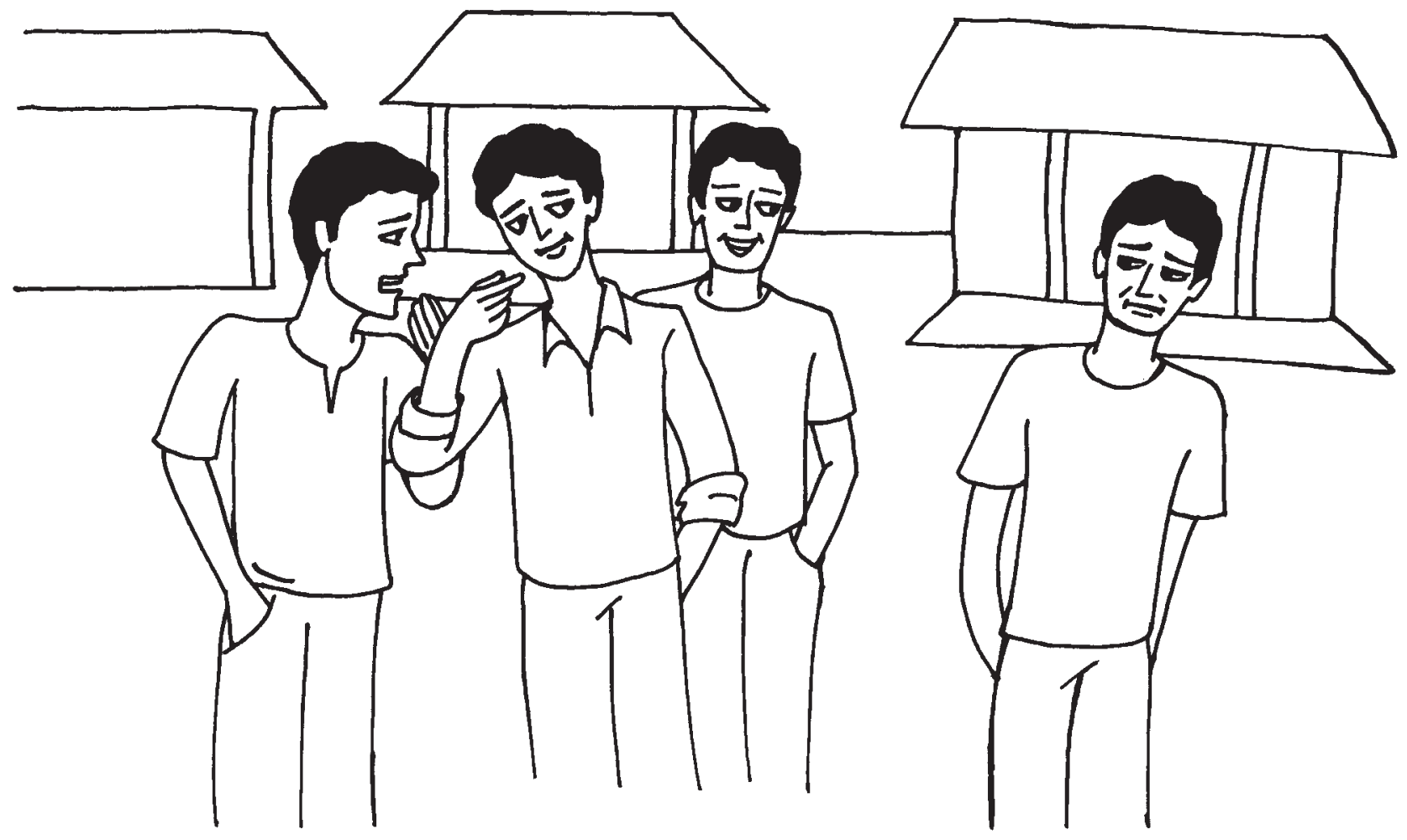

\section{सारांश}

- किसी तरह का ठप्पा लगने से लोगों पर क्या असर होता है?

- दूसरों के साथ बर्ताव करते समय हमें कौन सी बातों पर ध्यान देना चाहिये?
- शिक्षा का गलत इस्तेमाल, ब्लैकमेलिंग, किसी को ठेस पहुंचाने वाली बातें; हमें नही करनी हैं।

- हमें ठप्पे वाले नाम को लेकर किसी को चिढ़ाने, मजाक उड़ाने, ऊँच-नीच, गरीब-अमीर जैसे भेदभाव नहीं करने चाहिए।

\section{प्रेरक के लिए निर्देश}

- ठप्पों की पर्चियों को ठीक तरह चिपकायें ताकि वे गिरें नहीं।

- सत्र में गड़बड़ी, झगड़ा होने की संभावना ज्यादा होती है इसका ध्यान प्रेरक को रखना चाहिए।

- अगर सत्र में कभी गड़बड़ी या झगड़ा हो तो शिक्षक को सत्र को कुछ देर के लिए रोक देना चाहिए।

- प्रेरक को स्वयं भी इस सत्र में भाग लेना चाहिए।

- सत्र में ऐसे ही नामों के ठप्पे लें जिन्हें प्रतिभागी समझ सकें।

- किसी भी प्रकार से व्यक्तिगत तौर पर चर्चा न हो, इसका विशेष ध्यान रखें। 


\section{व्यक्ति और वस्तुएं}

उद्देश्य : आपसी यौन संबंधों में थोपे जाने वाले अधिकारों को पहचानना। इन अधिकारों का आपसी संबंधों पर होने वाले प्रभावों का विशलेषण करना। साथ ही सुरक्षित यौन संबंधों के लिये आपस में बातें, संवाद और समझदारी बढ़ाने के लिये प्रोत्साहित करना।

समय : 2 घटें।

नियोजन टिष्णी : आमतौर पर ऐसा देखने को मिलता है कि, जब कभी अधिकारों की भूमिका बदलती है और आज्ञा पालन करने वाला अधिकार जताने वाले की भूमिका में चला जाता है, तब वह खुद भी उन्हीं अधिकारों का प्रयोग करता है, जो कि उसे पहले अन्याय लग रहे थे। हमारे प्रेरक को यह बात पूरी तरह से ध्यान में रखनी चाहिये कि हमारे आपसी संबंध और जीवन में भी अधिकारों का प्रभाव पड़ता है। जो लोग अपने अधिकारों का दुरूपयोग करते हैं उनके प्रति दूसरों में अनादर रहता है और दबाव में उन्हें स्वीकारा नही जाता है। सामान्यतः यह भी दिखाई देता है कि जिस प्रकार एक पुरूष (कभी कभार महिलायें भी) अपने अधिकारों का इस्तेमाल करते हैं उससे दूसरे व्यक्ति को भी हानि पहुंचती है और ज्यादातर पुरूषों को और महिलाओं को भी इसकी कीमत चुकानी पड़ती है।

प्रक्रिया

- प्रतिभागियों को सत्र से परिचित कराएं, और उनसे कहें कि इसमें "व्यक्ति और वस्तु" दो समूह हैं। प्रतिभागियों को व्यक्ति या वस्तु, इन दोनों
में से किसी एक समूह में शामिल होने को कहें।

- ध्यान रखें कि दोनों समूहों में बराबर-बराबर सदस्य हों।

- प्रतिभागियों को नीचे दिये हुये नियमों को पालन करने के लिए कहें।

\section{वस्तुऐं}

- सोच नहीं सकतीं,

- उनमें भावनायें नहीं होतीं

- वह निर्णय नहीं लेती

- उन्हें यौन इच्छा नहीं होती।

- व्यक्ति जो भी कहे वही उन्हें करना होगा।

- अगर वस्तु कुछ करना चाहे या कहना चाहे तो उसे अपने व्यक्ति/मालिक से आज्ञा लेनी पड़ती है।

\section{व्यक्ति / मालिक}

- व्यक्ति सोच सकता है

- निर्णय ले सकता है

- उसमें यौन इच्छा होती है

- भावनायें होती हैं और वह जैसे चाहे वैसे किसी भी वस्तु का इस्तेमाल कर सकता है। 
"व्यक्ति या मालिक" के समूह से कहें, कि वह वस्तु के समूह में से किसी भी एक वस्तु का किसी भी तरह इस्तेमाल कर सकता है, और वस्तु को आज्ञा का पालन करना है। (ध्यान रहे यह गतिविधि बंद कमरें में ही हों)

- इस गतिविधि के लिये पूरे समूह को 20 मिनट का समय दें।

- अन्त में सभी को फिर अपनी जगह जाने को कहें।

\section{बातचीत के मुद्दें}

- इस अभ्यास से आपने क्या महसूस किया, या आपको क्या लगा?

- वस्तु वाले समूह से पूछें, व्यक्ति/मालिक ने आप के साथ कैसा बर्ताव किया?

- क्या अपनी रोजमर्रा की जिंदगी में हम एक दूसरे के साथ ऐसा बर्ताव करते हैं? ऐसा कौन करता है तथा क्यों करता हैं?

- क्या इस तरह के बर्ताव में हम बदलाव ला सकते है? कैसे?

\section{अंत में}

आपसी रिश्तों में अधिकारों को कैसे इस्तेमाल किया जाता है और क्यों किया जाता है, इस पर चर्चा करें। आमतौर पर वस्तु को अपने व्यक्ति/मालिक के प्रति गुस्सा आता है और उस व्यक्ति के खिलाफ वह अपनी भावना प्रदर्शित कर सकता है।
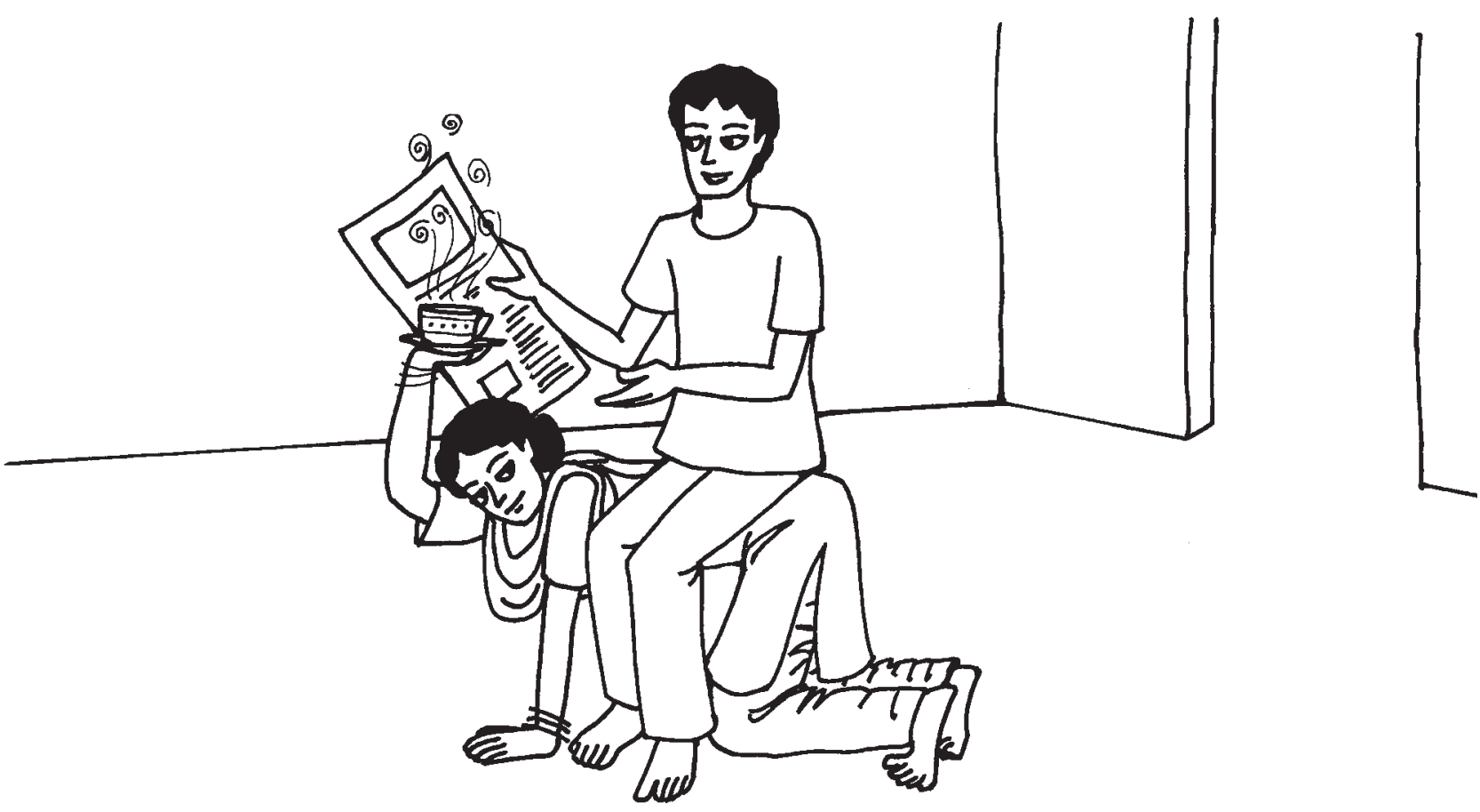
अभ्यास 1.5

\section{घरेलू कामः हम सिर्फ तभी ध्यान देते हैं जब उन्हें नहीं किया जाता है।}

उद्देश्य : घरेलू कामों से जुड़ी मान्यताओं तथा उनके बारे में सोचने के तरीकों की चर्चा करना तथा लड़के लड़कियों द्वारा घरेलू कामों को निपटाने के बारे में प्रश्न करना।

सामग्री: कोई भी सामग्री नहीं चाहिये।

समयः 1 घन्टा

तैयारी के लिए निर्देशः भूमिका बनाने के लिये प्रेरक वास्तविकता का सहारा ले सकते हैं जैसे- झाडू, पोंछा, एप्रेन, बर्तन साफ करने वाला कपड़ा इत्यादि। अभ्यास के दौरान, पौरुष और मर्दानगी के बारे में कुछ हँसी-मजाक हो सकते हैं। प्रेरक को इन हँसी-मजाकों की सीमा तथा इनसे होने वाले प्रभावों के बारे में सतर्क रहना चाहिये तथा इस बात का प्रयास करना चाहिये कि ये कम से कम हों। अधिकांश पुरुष कभी न कभी घरेलू कामों को निपटाते हैं तथा यदा-कदा हम इस पर चर्चा भी करते हैं। इस तरह के अनुभवों के आधार पर हम इस निष्कर्ष पर पहुँच सकते हैं कि घरेलू कामों का मर्दानगी/पोरुष से कोई सम्बन्ध नहीं है।

विधि

1. प्रतिभागियों को किसी घर के घरेलू कामों को निपटाने वाली भूमिका नाटिका प्रस्तुत करने को कहें। प्रत्येक प्रतिभागी को एक ही काम सौंपें।

2. किसी प्रतिभागी को काम करने से रोकें तथा बाकी सदस्यों को इस काम को आपस में बाँटने के लिये कहें।

3. अब दूसरे प्रतिभागी को भी रोक दें।

4. आखिरी प्रतिभागी तक इसी तरह कार्य विभाजित करते जायें।

5. अन्त में आखिरी प्रतिभागी को भी रोक दें।
6. समूह से पूछें कि - एक सप्ताह पश्चात् इस घर का स्वरूप कैसा होगा?

7. चर्चा की शुरूआत करने के लिये प्रतिभागियों द्वारा उनके अपने घर में उनके द्वारा किये जाने वाले घरेलू कामों के बारे में तथा इनसे जुड़े मूल्यों के बारे में प्रश्न करें।

\section{चर्चा के लिये प्रश्न}

- जब दूसरे प्रतिभागी को काम करने से रोका गया तो सभी प्रतिभागियों को कैसा लगा?

1 यह अभ्यास, गुया पारा कैपेसिटाडोरेस वाई कैपेसिटाडोरस एन सालुड रिप्रोडक्टिवा, न्यूयॉर्क: आईपीपीएफ, 1998, से लिया गया है। 
- आखिरी प्रतिभागी को कैसा लगा?

- नाटक में दिखाये गये कामों में से कौन से काम प्रतिभागी अपने घर में करते हैं?

- अधिकांशतः ऐसे कामों को कौन करता है?

- वह कौन से घरेलू काम हैं जिन्हें पुरुष प्राय: करते हैं?

- वह कौन से घरेलू काम हैं जिन्हें पुरुष बहुत कम करते हैं?
- क्या कोई व्यक्ति घर के कामों पर ध्यान देता है, या फिर वह सिर्फ तभी ध्यान देता है जब कि किसी काम को छोड़ दिया गया हो?

- सेना जैसी जगहों पर यह काम कौन करता है?

- इन कामों में तथा घरेलू कामों में क्या अन्तर है?

- बचपन में घरेलू काम किससे करवाये जाते हैं, लड़कों से या लड़कियों से?

- किसके खिलौने - लड़कों के या लड़कियों के - घरेलू काम-काज से सम्बन्धित होते हैं?

अन्त में : शिक्षक को घरेलू काम-काज की महत्ता, मूल्य तथा इनको न करने वालों के द्वारा इनकी कोई कीमत न आँकना जैसे मुद्दों को उठाना चाहिये तथा इस बात पर बल देना चाहिये कि स्त्री तथा पुरुष दोनों ही घरेलू काम-काज को निपटाने के लिये समान रूप से सक्षम होते हैं। किसी लड़की में ऐसी कोई विशेष बात नहीं होती है जो उसे घरेलू काम-काज के लिये उपयुक्त बनाती हो। इस प्रकार, जो भी महिलाओं या पुरुषों की मनोवृति में अन्तर है, वह सामाजिक धारणाओं के कारण आते हैं और हम इसी प्रकार 'स्त्री' या 'पुरुष' के रूप में बड़े होते हैं ना की एक व्यक्ति के रूप में।
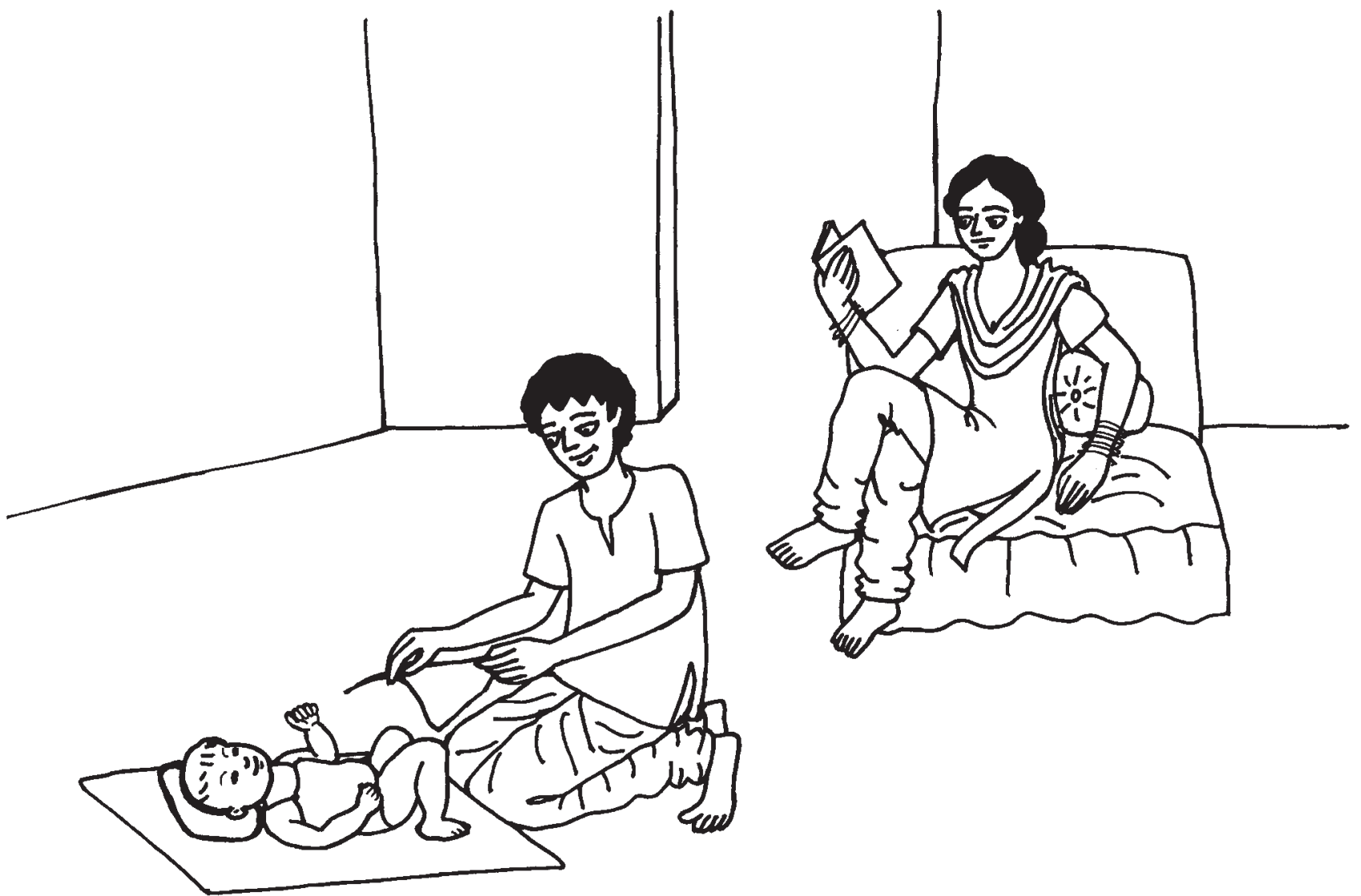


\section{उद्देश्य :}

- विशिष्ट प्रकार की भावना व्यक्त करते समय होनेवाली परेशानियों को पहचानना

- इन परेशानियों के वजह से हमारे मानसिक स्वास्थय पर होनेवाले प्रभावों का विशलेषण करना तथा

- यह समझना कि हम किस प्रकार अपनी कुछ भावनाओं को तो बढ़ा चढ़ा कर व्यक्त करते है तथा कुछ अन्य भावनाओं को दबा देतें है।

समग्री : बड़े कागज, पेन, पेन्सिल,

समय : 2.4 घंटे

\section{तैयारी के लिए निर्देश :}

युवाओं के साथ यह कार्याभ्यास करने से पहले प्रेरक को स्वंय अपनी भावनाओ की अभिव्यक्ति के बारे में विचार करना चाहिए। इस अभ्यास के दौरान यह बताना आवश्यक है कि कैसे प्रत्येक व्यक्ति अपने-अपने तरीकों से भावनाओं को व्यक्त करता या करती है। उदाहरण के तौर पर पुरुष आमतौर पर निडर दिखना चाहते हैं। वो अपने दुख को छुपाते हैं तथा सबके सामने रोना नही चाहते एवं अक्सर अपनी उदारता भी प्रदर्शित करनें में संकोच करते हैं। वो अपना गुस्सा अक्सर हिंसा के रुप में प्रदर्शित करते है। यह जानना जरूरी है कि जो अपनी भावनाओं को ठीक से व्यक्त नही कर पाते, वे उनमें उलझ कर रह जाते है या भावनाओं में बह जाते हैं। भावनाओं को "महसूस" करना एवं उनके "प्रदर्शन" के अंतर को समझना अत्यंत आवश्यक है। "महसूस" हम जैसा भी करें, भावनाओं के "प्रदर्शन" करते समय यह ध्यान रखना आवश्यक है कि दूसरों को किसी प्रकार की 'चोट' न पंहुँचे या हानि न हो। हिंसा रोकने के लिए यह अभ्यास काफी महत्वपूर्ण है। हमें दूसरों की भावनाओं को समझने से पहले अपनी भावनाओं को समझना जरूरी है।

\section{प्रक्रिया}

1. समूह को एक गोल घेरे में बैठने के लिए कहें और 'दूसरा मैं' यह कहानी पढ़ने के लिये कहें।

2. कहानी पढ़ने के बाद नीचे दिये हुये सवाल पूछें

a. इस कहानी में आपका ध्यान सबसे ज्यादा कहॉ आकर्षित हुआ? b. कहानी में से ऐसी बातें बताऐं जो रोजमर्रा की जिंदगी से संबंधित है?

c. थोड़ी देर के लिए उन बातों को सोचने के लिए कहें जो छूट गई है जैसे बर्ताव-व्यवहार और भवनायें-आप क्या सोचते हो? ऐसा क्यों हुआ? 
d. इस कहानी के मुख्य मुददे क्या थें और इनमें से किन क्षेत्रों में व्यवहारिकता और भावनाओं को आगे जाकर विकसित किया जा सकता हैं?

3. समूह से पूछे उनका पसंदीदा खाना क्या है? सभी को जवाब देंने का मौंका दें, फिर दूसरा सवाल करें सबसे कम पसंदीदा खाना कौन सा है? उन्हें यह स्पष्ट करके बतायें कि खाने में हमारी पसंद और नापसंद से भी हमारी भावनाऐं जुड़ी हुई है। कुछ भावनाओं को हम आसानी से व्यक्त कर लेते हैं जबकि कुछ भावनाओं को हम अच्छे तरीके से व्यक्त नही कर पाते हैं और उसे टालने की कोशिश करते हैं।

4. बोर्ड पर पाँच विभिन्न भावनायें लिखें और सहभागियों से पूछें और समूह को बतायें की इन्ही भावनाओं को हम इस अभ्यास सत्र में चर्चा करेगें जैसे : डर, लगाव, दुखी होना, खुशी।

5. अब यह बतायें की इस कार्याभ्यास के माध्यम से हम यह जान सकते है कि शरीर के किस हिस्से में ये भावनायें महसूस होती है और हम किस तरह एक भावना को दूसरी भावनाओं से अलग रख सकते हैं।

6. समूह को यह बतायें की निम्नलिखित तरीकों से यह कार्याभ्यास का प्रयोग व्यक्तिगत तौर पर किया जाना है।

- उस भावना को नंबर 1 दें जो वह ज्यादा आसानी से व्यक्त करता है।

- उस भावना को नंबर 2 दें जो वह आसानी से व्यक्त नही कर सकता है।

- उस भावना को नंबर 3 दें, जो 1 और 2 के बीच में आती है, जो व्यक्त करने में ज्यादा कठिन भी नही है और आसान भी नही है।

- उस भावना को नंबर 4 दें जिसे व्यक्त करने में उसे अधिक परेशानी होती है।
- उस भावना को नंबर 5 दें जिसे व्यक्त करनें में उसे सबसे अधिक परेशानी होती है या वो भावना व्यक्त करने से इन्कार कर देता है।

7. इस कार्याभ्यास में हर एक को भाग लेना अत्यावश्यक और महत्वपूर्ण है, अगर समूह बड़ा हो तो उसे छोटे समूहों में विभाजित करें।

8. छोटे छोटे समूहों में चर्चा करते वक्त कौन सी बातें सामने आयीं, इन पर चर्चा करें और नीचें दी गई बातों को स्पष्ट करें।

- हमने जिन्हें नंबर 1 और 2 में रखा है वह भावनायें हम बढ़ा चढ़ाकर व्यक्त करते है।

- 4 और 5 नंबर की भावनायें हम कम पैमाने पर व्यक्त करते है।

- 3 नंबर की भावना को हम अधिक सहजता से व्यक्त करते है।

\section{चर्चा के मुद्दे}

- हम अपनी कुछ भावनाओं को तो कभी-कभी दबा कर रखते हैं और अन्य भावनाओं का बढ़ा चढ़ा कर प्रदर्शन करते है। ऐसा क्यों होता है?

- इन पाँचों भावनाओं को यदि हम दूसरे लोगों के साथ जोड़ कर देखते हैं तो क्या होता है? (दूसरे लोग जैसे-दोस्त, साथी, परिवार के सदस्य इत्यादि)

- हमारे जीवन में भावनाओं का क्या महत्व है? (उदाहरण दें, डर हमें खतरनाक परिस्थितियों से बचाता है : उसी तरह गुस्सा करने से हम अपना बचाव करते हैं)

- हमें अपनी भावनाओं को खुलकर व्यक्त करने के लिए क्या करना चाहिए? (सभी प्रतिभागी अपने व्यक्तिगत अभिव्यक्ति की नोट बनाये और अगर वो चाहें तो अपनी अभिव्यक्ति को समूह के दूसरे लोगों के साथ बांट सकते हैं।) 


\section{आखिर में}

- अंत में प्रेरक को इस बात पर बल देना चाहिए कि भावनाओं को ऐसी उर्जा के रूप में देखना चाहिए जो हमें यह बताता है कि कौन सी बात/चीज हमें परेशान कर रही है और हमारी कार्यक्षमता को प्रभावित कर रही है?

- अगर हम अपनी भावनाओं को बगैर किसी को नुकसान पहुंचाए प्रदर्शित करते हैं तो यह हमें मानसिक तौर पर मजबूत बनाता है तथा अपने आस-पास के वातावरण में अपने आप को ढालने में मदद करता है।

- कुछ बातें हम पर जन्म से थोप दी जाती हैं जैसे- लड़के को डरपोक नही होना चाहिए, लड़कियों को गुस्सा नहीं करना चाहिए। प्रेरक को इस बात पर जोर देना चाहिए कि भावनाऐं लड़के के हों या फिर लड़कियों के, इसे व्यक्त करने की आजादी दोनों को सामान रूप से है।

- प्रेरक को लगातार इस बात पर जोर देना चाहिए कि हम अपनी भावनाओं के बारे में जितना जागरूक होंगे उतनी ही हमारी भावनात्मक एवं मानसिक स्वास्थ अच्छी रहेगी।

- उन्हे यह बातायें कि भावनाएं ना तो अच्छी होती हैं और ना ही बुरी, ना वह लड़का होता है और ना ही लड़की बल्कि यह मनुष्य का एक अनिवार्य अंग है।

- यह भी बतायें कि किसी भी भावनाओं के प्रदर्शन के लिए हम जिम्मेदार नहीं हैं, हम वही करते हैं जो हम सोचतें हैं। गुस्से के संदर्भ में यह जरूरी है कि समूह के सदस्य हिंसा और कोध के मौखिक प्रदर्शन के अन्तर को समझ लें।

सत्र का अंत इस प्रश्न के साथ करें; क्या आपने इन अभ्यासों से कुछ नई चीजों को सीखा है?

\section{दूसरा मैं}

यह कहानी एक साधारण लड़के की है: उसकी पैन्ट घुटने से फटी हुई थी; वह कॉमिक्स पढ़ता था, खाना खाते वक्त मुँह से आवाज निकालता था; अपने नाक में उंगली डालता था; सोते समय खर्राटे लेता था। उसका नाम विजय था। विजय हर मायने में साधारण था, सिवाय एक चीज के, वह दूसरा विजय था।

इस दूसरे विजय में एक अजीब सा जादू था। वह फिल्मों के हिरोइनों से प्यार करता था। झूठी कहानियॉ बनाना या झूठ बोलना इस दूसरे विजय को बखूबी आता था। सूरज ढलते ही उसकी भावनायें उमड़ कर आती थी। विजय को इस दूसरे विजय की चिंता लगी रहती थी। दूसरा विजय ज्यादातर उदास रहता था एवं भावुक था। विजय जैसी हर बात पर वह हँस नहीं सकता था। विजय को इस बात की चिंता रहती थी कि यदि उसके दोस्तों को इस संवेदनशील "दूसरा मैं' का पता लगा तो वे क्या सोचेगें।

एक दिन विजय दोपहर को थका मादा घर आया, जूते निकालकर उसने पैर ढीले किये और रेडियो ऑन कर दिया, रेडियो पर नौशाद जी का शास्त्रीय संगीत चल रहा था। विजय की आँख लग गई पर जब उसकी आँख खुली तो दूसरा विजय रो रहा था। पहले तो वह घबरा गया, करें तो क्या करें यह विजय को कुछ समझ में नहीं आ रहा था, पर उसने अपने आप को संभाला और दूसरे विजय को बहुत ही भला बुरा कहा। लेकिन दूसरा विजय चुपचाप सुन रहा था और अगले ही दिन उस दूसरे विजय ने आत्महत्या कर ली।

पहले तो दूसरे की मौत से बेचारे विजय को बड़ा झटका लगा पर बाद में विजय ने सोचा की अभी दु:खी और भावुक ना होकर वह हमेशा की तरह सामान्य बर्ताव कर सकता था। यह विचार आते ही वह खुश हो गया। 
पाँच दुःख भरे दिन गुजर गये। अपने नये और सुधरे हुये व्यक्तित्व का प्रदर्शन करने हेतु विजय बाहर निकला, दूर से ही उसके दोस्त एक साथ आते हुये दिखाई दिये। उनके देखने पर उसे खुशी हुई और हंसी भी आ रही थी, पर वे उसके सामने से गुजरे तब भी उन्होंने विजय की ओर ध्यान नही दिया और सबसे बुरी बात तो यह की वो लोग आपस में यह बात कर रहें थे की अरे बेचारा विजय कितना अच्छा था, किसी को भी विश्वास नहीं होगा कि उसने आत्महत्या की है। यह बात विजय ने सुनी।

यह सुनते ही उसकी हँसी रूक गई। उसी समय उसके दिल में जबरदस्त झटका लगा, बीते हुये दिनों कि बातें उसे याद आ रही थीं। लेकिन असली दुःख का एहसास उसे नहीं हुआ, कारण था दूसरा विजय, जो कि सभी दुःखों को अपने साथ ले गया।

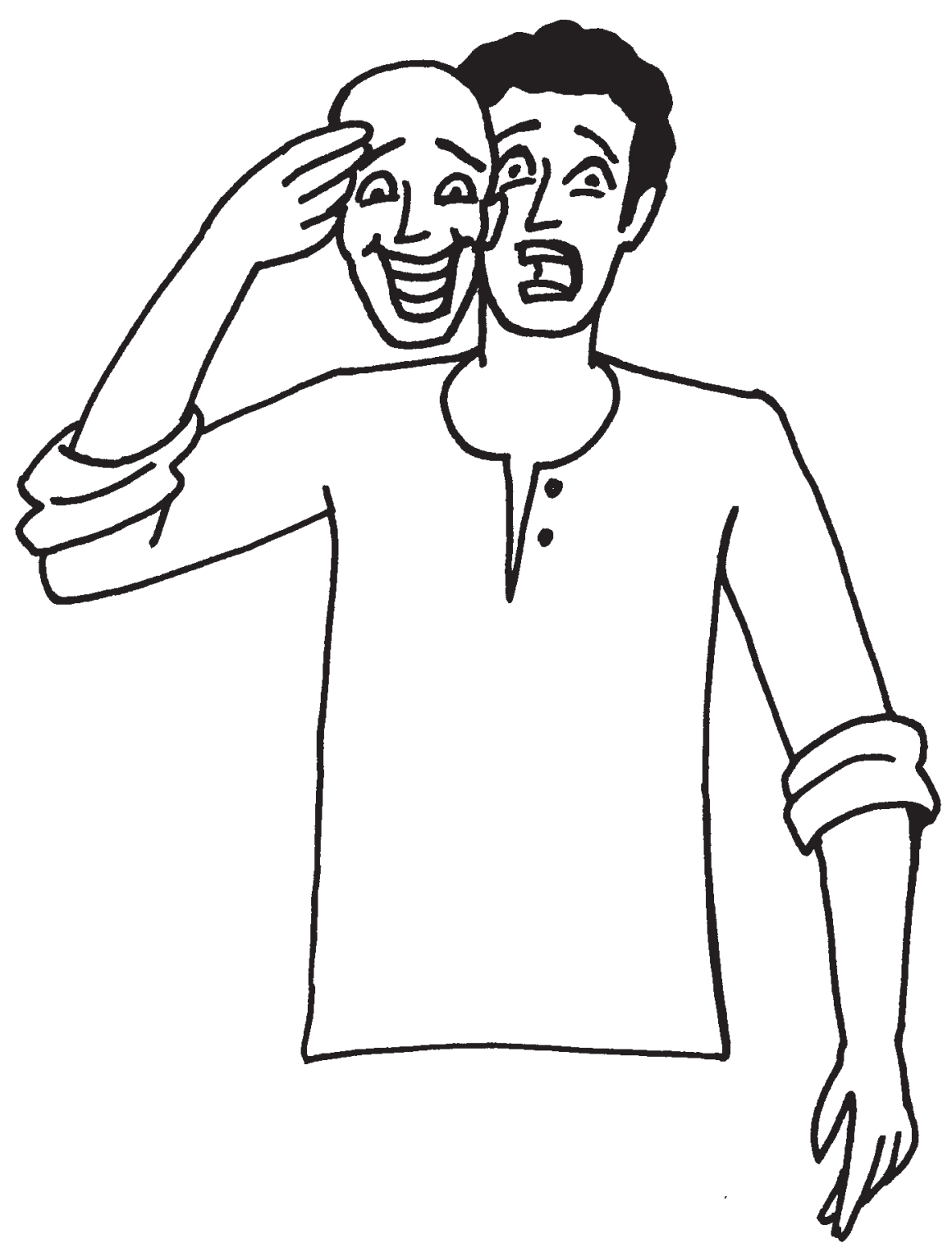




\section{निर्णय लेने के कारण तथा भावनाएँ}

उद्देश्य : शराब पीने के संबंध में निर्णय लेने पर विचार करना।

सामग्रीः प्रत्येक प्रतिभागी के लिए प्रश्नावली, फ्लिप चार्ट और सकेच पेन।

समयः 1 घन्टा 30 मिनट

योजना बिन्दु/निर्देशः विभिन्न विचारों के लिए आदर एवं खुलेपन का वातावरण बनाना जरूरी है। प्रश्नावली की प्रतिलिपियां बनाने या फ्लिप चार्ट में बड़े अक्षरों में लिखने से सहायता मिलेगी।

प्रक्रिया

\section{पहला भाग}

1. प्रश्नावली को सभी प्रतिभागियों से दो संभावित उत्तरों के साथ भरने को कहें। 'हाँ' या 'न' और अगर 'हाँ' तो क्यों और 'न' तो क्यों? (संसाधन पत्रक, फ्लिप चार्ट)।

2. प्रतिभागियों को सवालों के जवाब एक-दूसरे के साथ बाँटने चाहिए। अगर समूह बड़ा हो, तो उसे 10 प्रतिभागियों के अलग-अलग समूह बना सकते हैं।

3. प्रत्येक प्रतिभागी से कहें कि वह अपने जवाबों को पढ़ें और फ्लिप चार्ट में दी गयी जानकारी से मिलाएं।

अन्त में निम्नलिखित विचारों को मजबूती प्रदान करना :

- किशोरों के शराब पीने के पीछे, साथियों का दबाव और देखा देखी की प्रवृति मुख्य कारण हैं।
- इस बात पर जोर दें, कि शराब पीने या न पीने का निर्णय निम्न कारकों पर आधारित होता है, स्वयं की धारणाएं, धार्मिक विश्वास, स्वास्थ्य के प्रति चिंता, सामाजिक या पारिवारिक मापदण्डों के अलावा दोस्त बनाने और मोज-मस्ती के विकल्प के रूप में भी होता है।

- प्रतिभागियों के साथ उन विकल्पों पर विचार करें जिनके माध्यम से बिना शराब के दोस्तों और समूह का साथ बातचीत किया जा सकता है।

\section{दूसरा भाग}

अन्य प्रश्नों को पूछते हुए अभ्यास को जारी रखें :

- ऐसे किसी व्यक्ति के साथ क्या होता है, जो अपने समाज में अपना धौंस जमाने के लिए शराब पीना जरूरी समझते हैं?

- आपके शराब पीने से किसी को चिंता क्यों होती है? यह दोस्ती है या जिम्मेदारी?

- कोई पहले से शराब पर आश्रित है, इस बात का पता हमें कैसे चलेगा? 
- समूह को बताएं कि सारणी 1 में दिये गये मापदण्डों के अनुसार शराब पीने के शुरूआती लक्षणों में से किसी एक लक्षण को याद रखना आवश्यक है। शराब के लगातार इस्तेमाल करने से व्यक्ति समाज में अपनी, इज्जत खो देता है।
- शराब पर आश्रित होने वाले शुरूआती लक्षण को पहचानने के लिए समूह को कुछ निर्देश दें। इसके लिए नीचे दी गयी सारणी का प्रयोग करें :

\section{सारणी 1: शराब पर निर्भर होने की शुरुआती पहचान के लिए मापदण्ड ${ }^{1}$}

1. अगली बार पीने के बारे में सोचना, बात करना या योजना बनाना।

2. सामान्य से अधिक मात्रा में शराब पी जाना।

3. जल्दी-जल्दी पीना।

4. क्या आप इसे तनाव दूर करने तथा हिम्मत देने के उपाय के रूप में ग्रहण करते हैं।

5. नशे में की गयी हरकत या घटना के बारे में भूल जाना।

6. शराब की आपूर्ति तथा उसे साथ रखने पर ध्यान देना।

7. सामर्थ्य से अधिक पीना या पीते ही चले जाना।

8. इसके अतिरिक्त सबसे अधिक संवेदनशील मापदण्ड यह है कि : नशे की हालत में किसी ऐसे काम के बारे में जो आपने किया है (अथवा नहीं किया हो) के बारे में चिंता जाहिर करना या माफी माँगना।

नोट:-उपरोक्त में से किन्हीं दो मापदण्डों के आधार पर कहा जा सकता है कि किसी व्यक्ति को शराब की लत लगने का खतरा है।

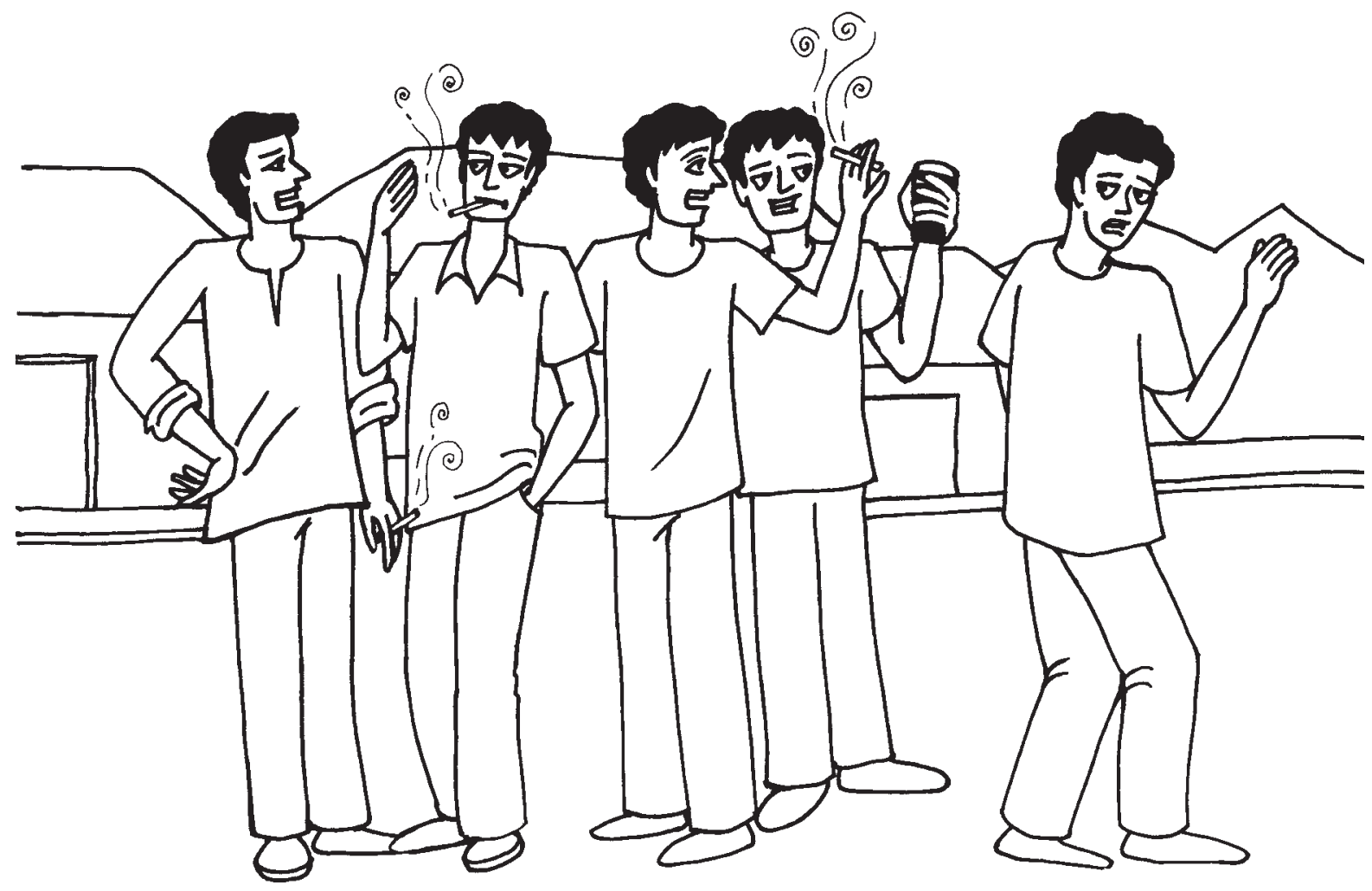

हैलियन रिचर्ड, अर्ली रिकॉग्नीशन ऑफ अल्कोलिज्म एण्ड अदर ड्रग डिपेन्डन्सीज इजेल्डेन, 1990 । 


\section{संसाधन पत्रक / फ्लिप चार्ट}

सारणी 2 : व्यक्तिगत प्रश्नावली : निर्णय लेना

निम्नलिखित प्रश्नों का सावधानीपूर्वक उत्तर 'हाँ' या 'नहीं' में दें।

\begin{tabular}{|c|c|c|}
\hline & हॉ & नही \\
\hline $\begin{array}{l}\text { 1. क्या आप अपने आपको उपेक्षित महसूस करते हैं यदि किसी पार्टी में आपके दोस्त } \\
\text { आपको शराब पीने के लिये कहते हैं और आप मना कर देते हैं। }\end{array}$ & & \\
\hline $\begin{array}{l}\text { 2. कल्पना कीजिये कि आप किसी ऐसी पार्टी में गये हैं जहाँ शराब परोसी जा रही है } \\
\text { तथा आप भी पी रहे हैं एवं अपने मित्र से शराब पीने को कहते हैं तो वह मना कर } \\
\text { देता है, तो क्या आप उसे हीन तथा उपेक्षित समझते हैं। }\end{array}$ & & \\
\hline $\begin{array}{l}\text { 3. क्या अपने दूसरे मित्रों के सामने अपने किसी मित्र के ऐसे विचारों का समर्थन करेंगे, } \\
\text { जो कि शराब नहीं पीना चाहता है। इससे आपके मित्र आपके बारे में क्या सोचेंगे } \\
\text { और क्यों? }\end{array}$ & & \\
\hline $\begin{array}{l}\text { 4. क्या आपको लगता है कि दोस्ती-यारी को बनाये रखने के लिये आपको दूसरों } \\
\text { की बात माननी पड़ती है? क्यों? }\end{array}$ & & \\
\hline $\begin{array}{l}\text { 5. क्या आपको लगता है कि शराब पिये बिना भी कोई व्यक्ति आनन्दमय सामाजिक } \\
\text { जीवन व्यतीत कर सकता है? क्यों? }\end{array}$ & & \\
\hline 6. क्या कोई व्यक्ति बिना शराब पिये अच्छा महसूस कर सकता है? क्यों? & & \\
\hline 7. क्या कोई किशोर बिना पिये हुये ही सामाजिक मान्यता प्राप्त कर सकता है? क्यों? & & \\
\hline
\end{tabular}


अभ्यास 1.8

\section{जीवन की लॉटरी}

उद्देश्य : युवकों में खुद के शरीर और स्वास्थ्य के प्रति जिम्मेदारी का अहसास बढ़ाना।

सामग्री-पेन्सिल, कागज, जीवन की लॉटरी की संसाधन पत्रक / शीट, बोर्ड

\section{प्रकिया}

- प्रत्येक प्रतिभागी को जीवन की लॉटरी की संसाधन पत्रक बॉट दें।

- प्रेरक संसाधन पत्रक में दिये गए प्रत्येक प्रश्न को एक एक कर बोर्ड पर लिखें तथा समूह को उनके उत्तर अपने संसाधन पत्रक पर ग का निशान बनाकर देने को कहें।

- उन्हें बताऐं कि प्रत्येक प्रश्न के बाद तीन खंड (कॉलम) है, स्त्री, पुरूष एवं दोनों। उत्तर केवल एक ही कॉलम में देना है।

- समूहों के दिये हुये जवाबों पर चर्चा करें।

- आखिर में इस बात पर भी चर्चा करें कि सभी विभागो में पुरूषों की संख्या ज्यादा है। क्या आप लोगों को यह पता था, ऐसा क्यों होता है? आपको क्या लगता है? इसे कैसे रोकना चाहिए?

\section{चर्चा के सवाल}

- स्त्री और पुरूषों की कौन-कौन से कारणों के वजह से मौत होती है? इसके लिए जिम्मेवार कौन है? आपको क्या लगता है?

- पुरूष अपने स्वास्थ्य के प्रति सर्तक रहें तो हालात में बदलाव आयेगा?

- पुरूषों में किस प्रकार का तनाव रहता है? क्यों?

- औरतों में किस प्रकार का तनाव रहता है? क्यों?

- आप बीमार पड़ते हैं तो क्या करते हैं?

- अगर आप बीमार पड़ते हैं तो किसकी मदद लेते हैं?

- आप कितनी बार डॉक्टर के पास जाते हैं?

- अच्छा दिखने के प्रति सबसे ज्यादा कौन सचेत रहता है? पुरूष या औरत? क्यों?

\section{अंत में}

- बहुत से पुरूषों का जीवन शैली काफी आत्मघाती होता है। पुरूषों के मौत का जिम्मेदार उनकी गलत जीवन शैली है।

- उन्हे यह भी बताऐं की खुद के स्वास्थ्य के प्रति सचेत रहने से बदलाव लाया जा सकता है। 


\section{संसाधन पत्रक / शीट}

जीवन की लॉटरी

\begin{tabular}{|c|c|c|c|}
\hline & स्त्री & $\begin{array}{l}\text { प्र } \\
\text { पुरूष }\end{array}$ & $\begin{array}{l}\text { दोनों } \\
\text { क्र }\end{array}$ \\
\hline $\begin{array}{l}\text { किसका जीवन काल कम समय का होता है? (किसकी अल्प आयु में मृत्यु होती है?) } \\
\text { खून खराबे में कौन ज्यादा मरता है? } \\
\text { सड़कों पर होने वाले दुर्घटनाओं में कौन ज्यादा मरता है? } \\
\text { कौन आत्महत्या ज्यादा करता है? } \\
\text { कौन ज्यादा हत्याऐं करता है? } \\
\text { कौन ज्यादा दारू पीता है? } \\
\text { बुढ़ापे में किसकी मौत ज्यादा होती है? } \\
\text { यौन रोग होने का खतरा किसे अधिक होता है? } \\
\text { एचआईवी होने का खतरा किसे अधिक होता है? }\end{array}$ & & & \\
\hline
\end{tabular}

प्रेरक के लिए जरूरी जानकारियाँ

\begin{tabular}{lcc}
\hline मौत के कारण & पुरूष & स्त्री \\
\hline संक्रमन की बीमारी & 15.4 & 13.5 \\
मानसिक बीमारी & 0.2 & 0.1 \\
हृदय संबंधित बीमारी & 24.6 & 22.4 \\
पाचन संबंधित बीमारी & 5.1 & 2.8 \\
वाह्य कारणों से मौत & & \\
15-24 उम्र & 19.7 & 15.8 \\
25-34 उम्र & 23.7 & 11.4 \\
35-44 उम्र & 17.0 & 11.4 \\
45-59 उम्र & 15.5 & 14.7 \\
दुर्घटना से हुई मौत & & 11.3 \\
15-24 उम्र & 7.2 & 7.2 \\
25-34 उम्र & 13.2 & 7.2 \\
35-44 उम्र & 10.2 & 10.3 \\
45-59 उम्र & 19.2 & \\
\hline
\end{tabular}

Source: Survey of Causes of Deaths (1998, Registrar General) in Health Information of India

उपरोक्त सारणी में यह दर्शाया गया है कि मौत के मुख्य कारणों में पुरूषों की संख्या अधिक है। हालांकि वाह्य कारणों से मौत तथा दुर्घटना से हुई मौत व्यक्ति की उम्र तथा वस्तुर्थिति पर निर्भर करता है। कहने का तात्पर्य यह है कि मौत के विभिन्न कारणों में पुरूषों की संख्या अधिक है क्योंकि ऐसा देखा जाता है कि पुरूष आमतौर पर अधिक खतरा लेते हैं और कई बार लापरवाही की वजह से उनकी मौत होती है। साथ ही यह भी पाया गया है कि पुरूष कभी कभी अपनी मर्दानगी साबित करने के लिए कुछ गलत कदम उठाता है जिनके कारण उनकी मौत हो सकती है। 


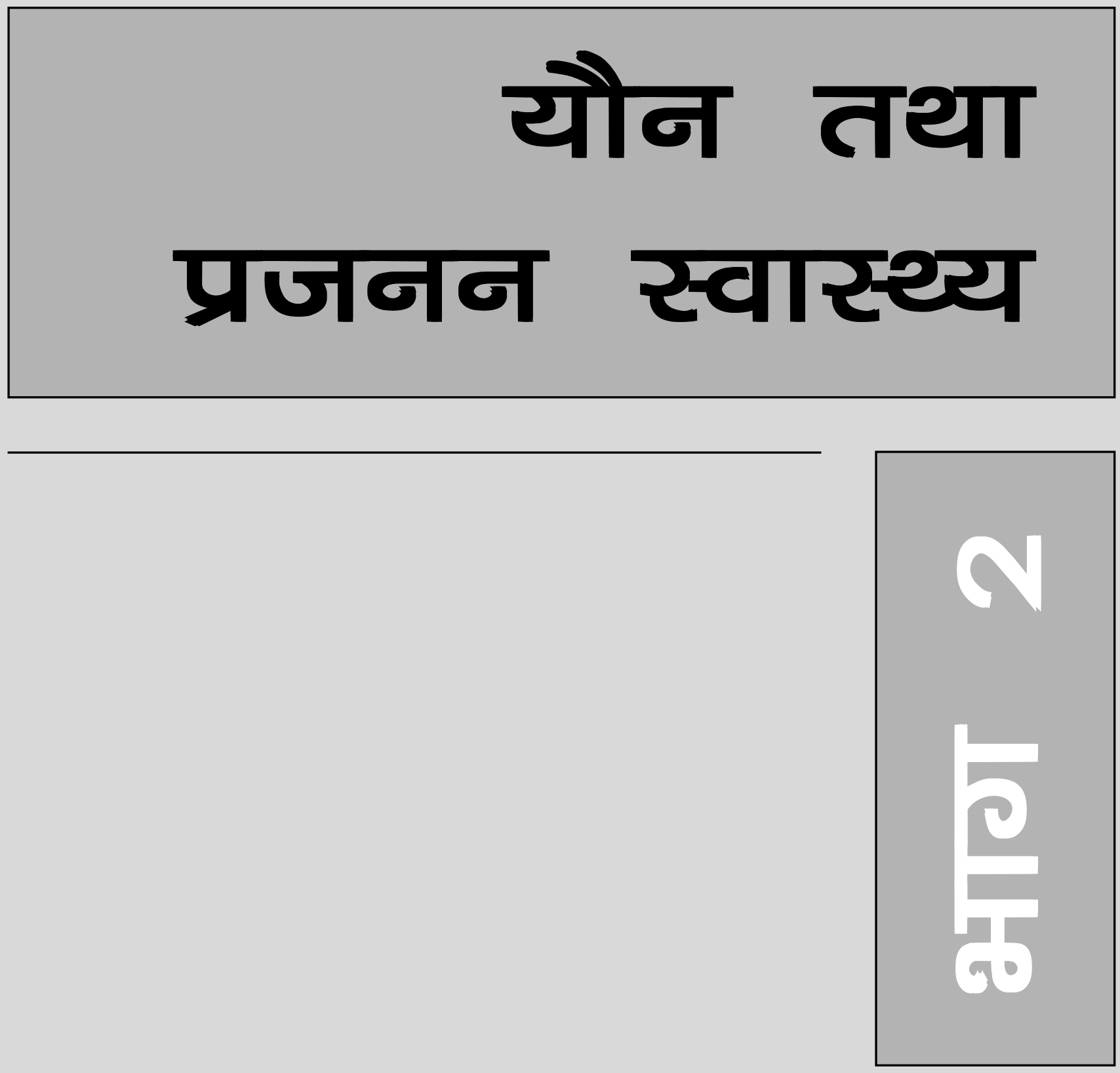

अभ्यास 2.1

में और मेरा शरीर

सारांश : इस अभ्यास द्वारा यह जाना जा सकता है कि युवक अपने शरीर की किस प्रकार देख-रेख कर सकते हैं, खास तौर पर प्रजनन स्वास्थ्य के संदर्भ में, यौन रोगों तथा एचआईवी से कैसे अपना बचाव कर सकते हैं।

उद्देश्य : शारीरिक स्वच्छता एवं प्रजनन स्वास्थ्य के बारे में चर्चा करना।

\section{सामग्री :}

- बड़े आकार का कागज, या फिर कागज के टुकड़े जिन्हें जोड़कर बड़ा बनाया जा सके, ताकि कोई भी व्यक्ति उस पर लेट सके और उसकी आकृति बनायी जा सके।

- मार्कर पेन, पुरानी पत्रिकाएं या अखबार।

- चिपकाने के लिए गोंद, कैंची।

समय: 2 घंटे

विधि

- प्रेरक प्रतिभागियों को सूचना दें कि, जो मानव चित्र हम बनाने जा रहे हैं, उसे कोई भी नाम दे सकते हैं। जैसे कि - यह सोया हुआ राहुल है।

- जमीन पर आदमी के आकार का एक कागज बिछा दें।

- उस कागज पर समूह में से किसी भी सदस्य को (जो स्वयं तैयार हो) को लेटने के लिए कहें और किसी दूसरे को उस व्यक्ति के शरीर की वाह्य रेखाचित्र (आउट लाइन) बनाने को कहें।

- उसके बाद फिर से किसी और ऐच्छिक सहभागी को पुरुष के जननांगों / लिंग का चित्र उस आकृति पर बनाने के लिए कहें।

- इसी तरह समूह के सभी सदस्यों को बारी-बारी शरीर के सभी अंगों के चित्र बनाने को कहें।
- शरीर के हर हिस्से को स्थानीय भाषा में नाम देने के लिए कहें। (खास तौर पर यौन अंगों के बारे में।)

- बदन पर जिस-जिस जगह गंदगी या मैल जमा हो जाता है या हो सकता है ऐसी जगहों पर, पुराने मासिक / किताबें/अखबार/कागज के छोटे-छोटे टुकड़े चिपकाने के लिए समूह के सदस्यों से कहें।

- एक सदस्य केवल एक अंग पर टुकड़ा चिपकाएगा, जहां पर की वह समझता है कि गंदगी जमा हो सकती है।

- धीरे-धीरे शरीर का अधिकांश हिस्सा कागज के टुकड़ों से भर जाएगा। इस समय समूह से चर्चा करें कि, हमारी सेहत पर शरीर की गंदगी का क्या असर होता है? 
- आकृति में बनाये गये युवक की क्या हालत हुई है? उसके सुधार के लिए क्या करना चाहिए? इसको लेकर समूह से चर्चा करें। समूह के सभी सदस्यों को चिपकाए हुए कागज के टुकड़ों को एक-एक करके निकालने के लिए कहें।

\section{चर्चा के मुद्दे}

- शरीर के हर हिस्से का क्या महत्व है और उसका क्या उपयोग है?

- शरीर का कौन सा हिस्सा अगर ना भी हो तो कोई परेशानी नही हागी। आपको ऐसा क्यों लगता है?
- शरीर की स्वच्छता का क्या तात्पर्य है?

- हमारे जीवन में शरीर साफ रखने का क्या महत्व है?

- यौन स्वास्थ्य के संबंध में शारीरिक स्वच्छता के अलावा और क्या करना चाहिए?

- क्या स्त्री एवं पुरुष दोनों ही अपने शरीर की देखभाल/स्वच्छता एक प्रकार से कर सकते हैं? इसमें क्या-क्या बाधाएं आती हैं?

- शारीरिक स्वच्छता न होने से कौन से यौन रोग होने की संभावना रहती है?

\section{अंत मे}

कार्याभ्यास के दौरान समूह के चर्चा के दौरान जो बातें सामने आयीं हैं, उन बातों के आधार पर प्रेरक को, शारीरिक स्वच्छता, और खासतौर पर यौन स्वास्थ्य की देखभाल का क्या महत्व है?, जैसी बातें समूह को अच्छी तरह से समझानी चाहिए। जिससे कि वह बातों को ठीक से समझ सकें। शरीर की स्वच्छता और योन रोगों का आपस में क्या संबंध है, यह भी स्पष्ट करें। 


\section{प्रजननता और गर्भनिरोधक}

उद्देश्य : गर्भनिरोधक के बारे में जानकारी देना और मर्दों के गर्भनिरोधकों के इस्तेमाल में भागीदारी के सम्बन्ध में चर्चा करना और साथ में उपयुक्त गर्भनिरोधक चुनने की विधि।

अनुमानित समय : 1 घन्टा 30 मिनट

सामग्री : गर्भनिरोधक के सैम्पल और / या गर्भनिरोधक विधि के चित्र, कागज़, पेंसिल और पेन, रिर्सोस शीट। शुरू करने की विधियॉ : अगर हो सके तो सभी गर्भनिरोधक (कॉन्डोम, कॉपर-टी, गर्भनिरोधक गोली या जो भी उपल्बद्ध हो) के एक-एक सैम्पल ले कर आयें। उपलब्ध गर्भ निरोधक की चर्चा के दौरान, गर्भनिरोधक के फायदे और नुकसान, साथ में सभी विधियों के सामाजिक और व्यक्तिगत सोच के बारे में भी चर्चा करें।

\section{विधि}

1. प्रतिभागियों को 6 दलों में बॉट दे। इन दलों के बीच विभिन्न प्रकार के गर्भनिरोधक या उनके चित्र को वितरित कर दें और उनके बारे में ज़रूरी जानकारियाँ प्रत्येक दलों को दे दें।

दल 1. प्राकृतिक विधि

दल 2. आई. यू. डी. विधि

दल 3. बैरियर विधि

दल 4. रिदम विधि

दल 5. नसबन्दी विधि

दल 6. आपातकालीन गर्भनिरोधक; गर्भनिरोधक गोली

2. प्रत्येक दलों को जो गर्भनिरोधक विधि दी गयी है उनके बारे में निम्न प्रकार का उत्तर देने की कोशिश करने को कहें -

- यह विधि कैसे गर्भधारण होने से रोकता है?

- इसका इस्तेमाल कैसे होता है?
- इस विधि के बारे में भ्रान्तियाँ और विशेषतायें क्या है?

- इसके फायदे क्या हैं?

- दल की इस विधि के बारे में क्या राय है?

3. जब उपरोक्त कार्य हो जाये तब प्रत्येक दलों को एक रिर्सोस शीट दे दें ताकी अगर उन्हें गर्भनिरोधक के बारे में कोई शंका या सवाल हो तो उसके बारे में जानकारी मिल सके।

4. उन्हें अपने अनुसार ही उनको दिये हुए गर्भनिरोधक विधि के बारे मे एक प्रस्तुतिकरण तैयार करने को कहें। इसके लिये वो नाटक तैयार कर सकते हैं, पोस्टर बना सकते हैं, कॉमिक्स बना सकते हैं, या फिर कोई टी. वी. कामर्शियल इत्यादी।

5. सभी ग्रुप उनको दी गयी गर्भनिरोधक विधि के बारे में प्रस्तुतिकरण प्रस्तुत करने को कहें। 


\section{चर्चा के प्रश्न}

- गर्भनिरोधक के बारे में किसे सोचना चाहिये? आदमी को या औरत को? और क्यों?

- इस बारे में किसे बात करनी चाहिये? मर्द को या औरत को? और क्यों?

- आपके अनुसार यह वार्तालाप किस प्रकार की होगी?

- युवा वर्ग के लिये सबसे उपयुक्त गर्भनिरोधक विधि कौन सी है? और क्यों?

- यौन जीवन शुरूआत करने से पहले चिकित्सक की सलाह क्यों ज़रूरी है?
- जिस प्रकार का गर्भनिरोधक एक दम्पत्ति इस्तेमाल करना चाहते हैं उसका चुनाव वह किस प्रकार करेंगे?

- कॉण्डोम इस्तेमाल के समय कौन-कौन सी सावधानियाँ बरती जानी चाहिये?

- ऐसी कौन सी एक गर्भनिरोधक विधि है जो गर्भधारण होने से रोकता है और एस.टी.आई. और एड्स से बचाता है?

- अगर आप कण्डोम का इस्तेमाल करना भूल जाते हैं या फिर अगर कॉण्डोम फट जाता है, तो आप क्या कर सकते हैं?

\section{और आखिर में}

- दलों में अतिरिक्त जानकारी की ज़रूरत के अनुसार, प्रत्येक गर्भनिरोधक विधि के बारे मे फिर से चर्चा करें और किसी भी प्रकार की शंका या सवाल को दूर कर दें।

- पुरूष प्रजननता के बारे में चर्चा अवश्य करें। यह विषय ज़रूरी है क्योंकि यह पाया गया है कि मर्दों में, खास कर के युवा मर्दो में, प्रजननता के बारे में बहुत कम जानकारी है। बहुत से मर्द अपनी प्रजननता के बारे में कभी नहीं विचार करते और यह भूल जाते हैं कि उनमें यह क्षमता है कि वो जब भी किसी औरत के साथ सेक्स करेंगे, उसे गर्भवती बना सकते हैं। मर्द सामान्यतः हमेशा ही प्रजनित होते हैं जबकि औरतें एक खास समय में प्रजनित होती हैं।

- प्रतिभागियों से उन्हें दी हुई गर्भ निरोधक के इस्तेमाल में होने वाली मुश्किलों के बारे में पूछें। यह भी पता लगायें कि वो अपने साथी के साथ गर्भनिरोधक इस्तेमाल के सम्बन्ध में कैसे बात करेंगे। इनके अलावा, इन लोगों के स्वास्थ्य सेवाओं और गर्भ निरोधक की उपलब्धता के बारे में पूछें। इन सेवाओं के इस्तेमाल करने में होने वाली दिक्कतों के बारे में चर्चा करें, अगर वो किसी स्वास्थ्य केन्द्र के बारे में जानते हैं तो उसके इस्तेमाल में होने वाली परेशानियों के बारे में पूछें।

- युवाओं द्वारा स्वास्थ्य सेवाओं का इस्तेमाल करने के अधिकार और इन सेवाओं के इस्तेमाल में गोपनीयता के बारे में चर्चा करना भी लाभप्रद हो सकता है, ताकि युवा वर्ग बिना किसी संकोच के या भय (माता/पिता को पता लगने का) के किसी भी गर्भनिरोधक का इस्तेमाल कर सकते हैं।

- और आखिर में, इस बात में ज़ोर दें कि गर्भनिरोधक का इस्तेमाल करना एक ज़िम्मेदारी है और इस ज़िम्मेदारी को साथ मिल कर निभाना चाहिए। अगर दोनो यह नहीं चाहते कि उनके यौन सम्बन्धों से बच्चा हो तो यह दोनों के लिये ज़रूरी है कि वो सावधानी बरतें ताकि इस स्थिति का सामना ना करना पड़े। 
संसाधन पत्रिका

\begin{tabular}{|c|c|c|c|c|c|c|}
\hline & सुरक्षित काल विधि & कापर टी० & अवरोधक / निरोध & रसायनिक & हारमोनल & शल्य प्रक्रिया \\
\hline 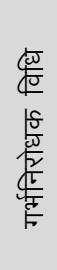 & $\begin{array}{l}\text { यह एक ऐसी विधि है } \\
\text { जो कि मुख्यतः औरत } \\
\text { और मर्द अपने शरीर } \\
\text { को समझने पर } \\
\text { इस्तेमाल करते हैं। }\end{array}$ & $\begin{array}{l}\text { यह एक छोटी सी } \\
\text { प्लास्टिक और तॉबे से } \\
\text { बना टी आकृति का यन्त्र } \\
\text { होता है जोकी स्वास्थ्य } \\
\text { कर्मी की सहायता से } \\
\text { महिलाओं के गर्भाशय के } \\
\text { अन्दर लगाया जाता है। }\end{array}$ & $\begin{array}{l}\text { यह विधि मर्द के वीर्य को } \\
\text { महिला के गर्भ तक जाने } \\
\text { से रोकता है। }\end{array}$ & $\begin{array}{l}\text { यह एक रसायन है इसे } \\
\text { जब महिला की योनी पर } \\
\text { रखा जाता है तो वो } \\
\text { पुरूष के स्पर्म को नष्ट } \\
\text { कर देता है या उसे } \\
\text { निष्क्रिय कर देता है। }\end{array}$ & $\begin{array}{l}\text { गोली या इन्जेक्शन } \\
\text { जो कि सिन्थेटिक } \\
\text { हारमोन से तैयार } \\
\text { होता है। }\end{array}$ & $\begin{array}{l}\text { यह सामान्यतः एक गर्भ } \\
\text { निरोधक नहीं है बल्कि } \\
\text { यह एक शल्य प्रकिया है } \\
\text { जो कि औरत या मर्द गर्भ } \\
\text { धारण से बचाव के लिये } \\
\text { इस्तेमाल करते है। }\end{array}$ \\
\hline$\frac{\frac{\nu}{f}}{5}$ & $\begin{array}{l}\text { रिदम } \\
\text { अधापतन }\end{array}$ & आई.यू.डी. & $\begin{array}{l}\text { महिला या मर्द के } \\
\text { कण्डोम } \\
\text { डायफ़ाग्म }\end{array}$ & कीम, जैली, फोम & $\begin{array}{l}\text { गेली, } \\
\text { इन्जेक्शन }\end{array}$ & $\begin{array}{l}\text { मर्द या औरत की } \\
\text { नसबन्दी }\end{array}$ \\
\hline$\sqrt{\frac{2}{8}}$ & $\begin{array}{l}\text { यह प्रजनन दौर में } \\
\text { गर्भधारण होने से रोकता } \\
\text { है, पर इसका इस्तेमाल } \\
\text { काण्डोम/डायफग्राम के } \\
\text { साथ करना चाहिये }\end{array}$ & $\begin{array}{l}\text { यह मर्द के वीर्य को महिला } \\
\text { के गर्भ तक जाने से रोकता } \\
\text { है }\end{array}$ & $\begin{array}{l}\text { यह मर्द के वीर्य को } \\
\text { महिला के गर्भ तक जाने } \\
\text { से रोकता है }\end{array}$ & $\begin{array}{l}\text { यह एक रसायन है जो } \\
\text { महिला की योनि पर } \\
\text { लगाया जाता है, इसे } \\
\text { काण्डोम और डायफाग्म } \\
\text { के साथ इस्तेमाल करना } \\
\text { चाहिये }\end{array}$ & $\begin{array}{l}\text { यह अण्डकोष से } \\
\text { अण्डा उत्पन्न होने } \\
\text { से रोकता है जिससे } \\
\text { कि सम्भोग होने के } \\
\text { बावजूद गर्भधारण } \\
\text { नहीं हो पाता। }\end{array}$ & $\begin{array}{l}\text { इसे मर्द या औरत कोई } \\
\text { भी करा सकता है, पुरूष } \\
\text { नसबन्दी में शुकाणुओं को } \\
\text { अण्डकोषों से लिंग तक } \\
\text { ले जाने वाली नालियों को } \\
\text { काट कर बान्ध दिया } \\
\text { जाता है। } \\
\text { स्त्री नसबन्दी दो प्रकार } \\
\text { से की जाती है: } \\
\text { टययबेक्टोमी के द्वारा } \\
\text { (फैलोपियन नलियों यानी } \\
\text { अण्डनलिकाओं को काट } \\
\text { कर बान्ध देना) या } \\
\text { लिप्रौस्कोप (दूरबीन द्वारा } \\
\text { अण्डनलिकाओं को थोड़ा } \\
\text { उठाकर, उठे हुऐ भाग } \\
\text { पर छाल्ला सा चड़ा कर } \\
\text { सिलाई का एक टॉका } \\
\text { लगा देना) }\end{array}$ \\
\hline 年 & $\begin{array}{l}\text { यह अपने शरीर को बेहतर } \\
\text { तरीके से समझने में मदद } \\
\text { करता है }\end{array}$ & $\begin{array}{l}\text { यह महिलाओं के लिये } \\
\text { एक आरामदायक और } \\
\text { इच्छानुसार परिवर्तन } \\
\text { करने के योग्य विधि है }\end{array}$ & $\begin{array}{l}\text { मर्द या महिला के } \\
\text { कण्डोम एस.टी.आई./ } \\
\text { एच.आई.वी./एड्स के } \\
\text { खतरे से बचाता है। } \\
\text { काण्डोम के इस्तेमाल } \\
\text { करने के लिये किसी } \\
\text { चिकित्सकीय सलाह की } \\
\text { ज़रूरत नहीं है और } \\
\text { आसानी से उपलब्ध होती } \\
\text { है। मर्दो द्वारा काण्डोम के } \\
\text { इस्तेमाल से गर्भनिरोधक } \\
\text { के बेहतर इस्तेमाल करने } \\
\text { में सहायक होती है। }\end{array}$ & $\begin{array}{l}\text { यह काफी प्रभावकारी है } \\
\text { यदि यह काण्डोम या } \\
\text { डायफ़ाग्म के साथ } \\
\text { इस्तेमाल किया जाये। }\end{array}$ & $\begin{array}{l}\text { अगर गर्भनिरोधक } \\
\text { गोली का इस्तेमाल } \\
\text { सही ढ़ंग से किया } \\
\text { जाये तब यह एक } \\
\text { बेहद प्रभावशाली } \\
\text { गर्भनिरोधक विधि है। }\end{array}$ & $\begin{array}{l}\text { यह काफी प्रभावशाली } \\
\text { और स्थायी उपाय है। }\end{array}$ \\
\hline 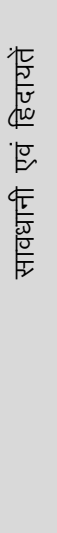 & $\begin{array}{l}\text { यह विधी एस.टी.आई./ } \\
\text { एच.आई.वी./एड्स से } \\
\text { नहीं बचाता है }\end{array}$ & $\begin{array}{l}\text { यह माहवारी के समय } \\
\text { स्राव को बढ़ा सकता है } \\
\text { या माहवारी की अवधि } \\
\text { बढ़ा सकता है। यह उन } \\
\text { औरतों के लिये उचित } \\
\text { नहीं है जिन्होंने अभी तक } \\
\text { बच्चे नहीं जने है। यह } \\
\text { एस.टी.आई./ } \\
\text { एच.आई.वी./एड्स से } \\
\text { नहीं बचाता। }\end{array}$ & $\begin{array}{l}\text { डायफ़ाग्म } \\
\text { एस.टी.आई./ } \\
\text { एच.आई.वी./ } \\
\text { एड्स से नहीं बचाता }\end{array}$ & $\begin{array}{l}\text { अगर इसे कण्डोम या } \\
\text { डायफ़ाग्म के बिना } \\
\text { इस्तेमाल किया जाये तो } \\
\text { इसके असफल होने के } \\
\text { आसार ज़्यादा हैं और यह } \\
\text { एस.टी.आई./ } \\
\text { एच.आई.वी./एड्स से भी } \\
\text { नहीं बचाता है }\end{array}$ & $\begin{array}{l}\text { इसे बेहद अनुशासित } \\
\text { तरीके से प्रतिदिन एक ही } \\
\text { समय में गोली लेनी होती } \\
\text { है। वो औरतें जो की } \\
\text { धूम्रपान करती हैं, ब्लड } \\
\text { प्रेशर की शिकायत हो, } \\
\text { उन्हें इस विधि का } \\
\text { इस्तेमाल नहीं करना } \\
\text { चाहिये। अगर इसे किसी } \\
\text { अन्य गर्भ निरोधक विधि } \\
\text { के बिना इस्तेमाल किया } \\
\text { जाये तो यह एस.टी. } \\
\text { आई / एच.आई.वी. से } \\
\text { बचाव नहीं करता है। }\end{array}$ & $\begin{array}{l}\text { यह काफी प्रभावशाली है } \\
\text { और इसके असफल होने } \\
\text { के आसार बहुत ही कम } \\
\text { हैं। }\end{array}$ \\
\hline
\end{tabular}




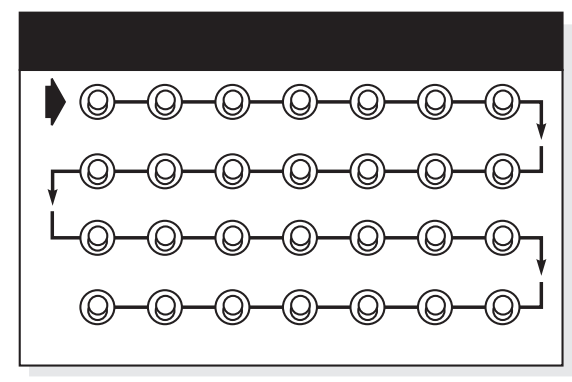

खानेवाली गोलियां

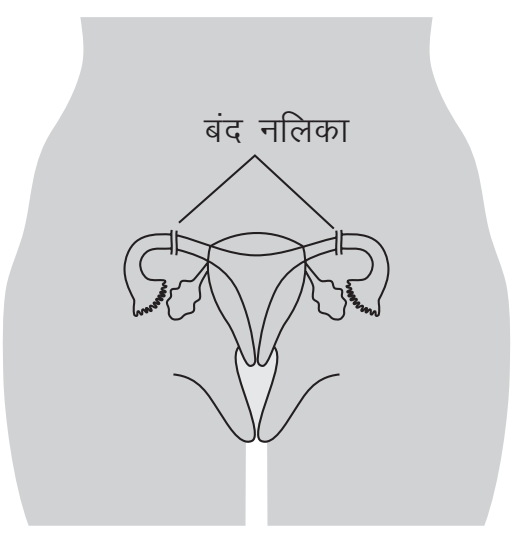

महिला नसबंदी
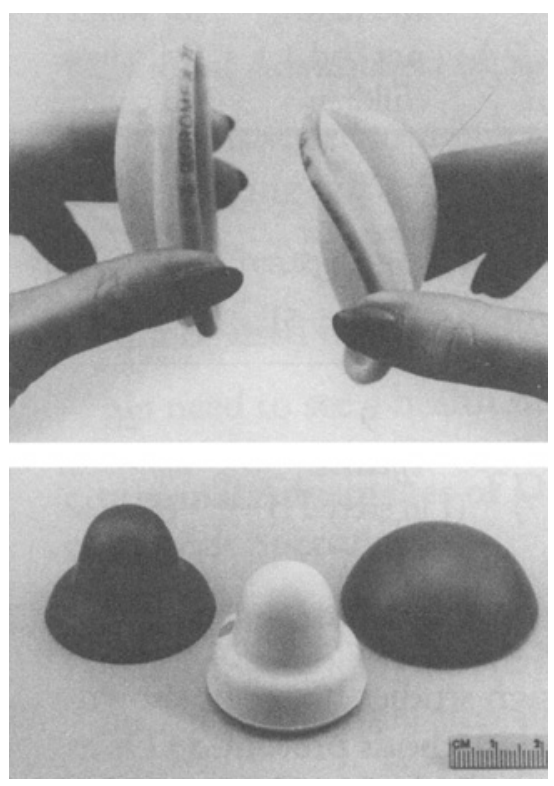

डाईफ्राग्म

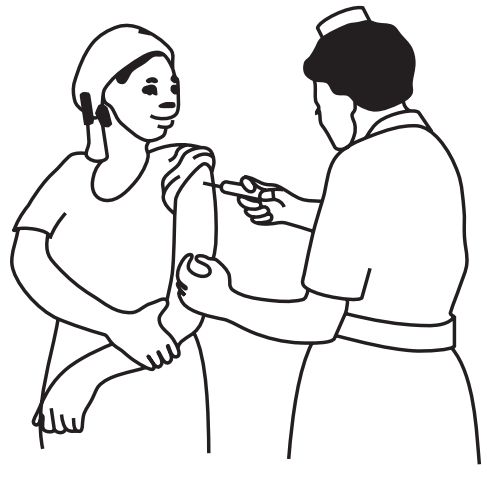

इंजेक्शन विधि

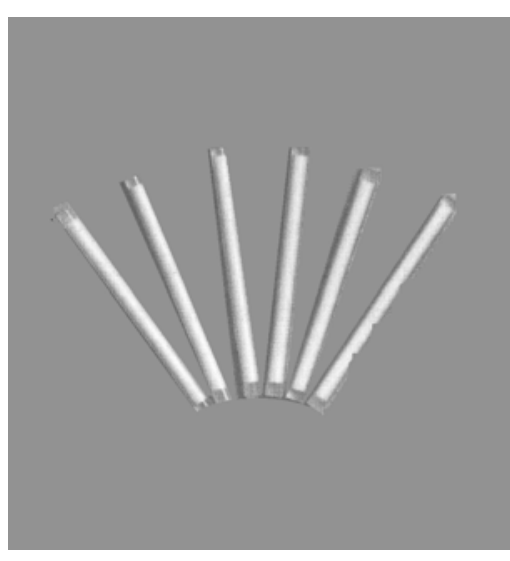

नॉरप्लांट विधि

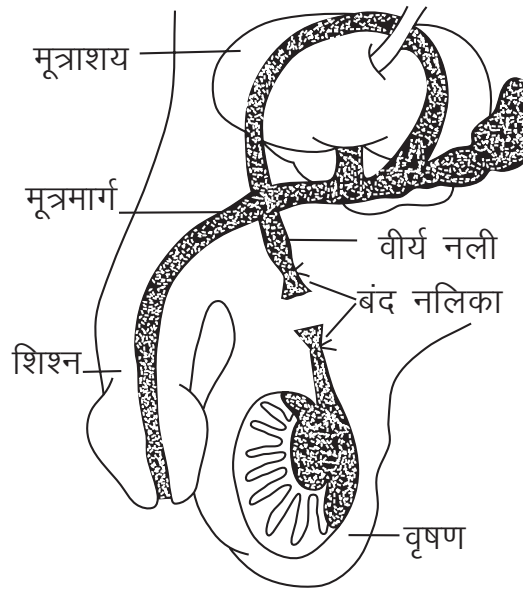

पुरूष नसबंदी

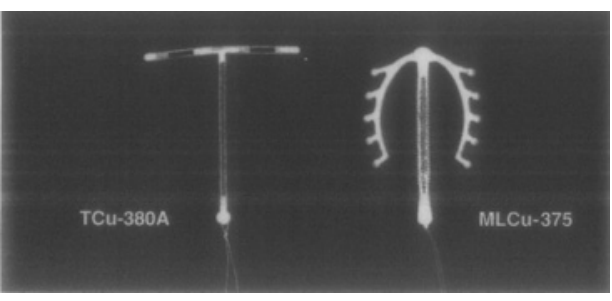

आई. यू. डी.

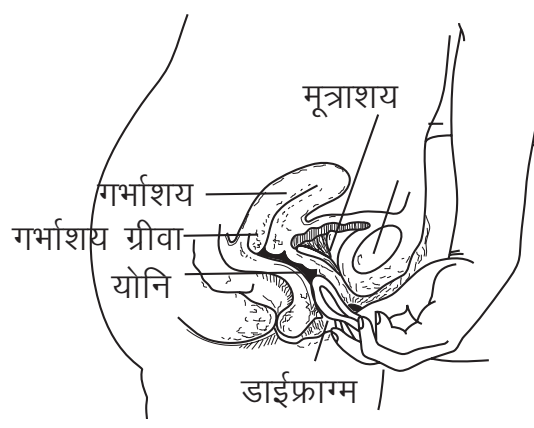

डाईफ्राग्म लगाने की विधि

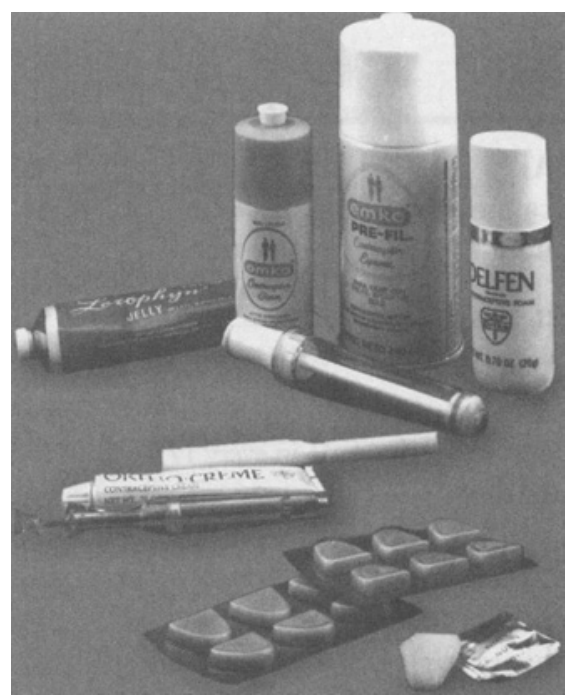

जेल/फोम विधि 
अभ्यास 2.3

\section{बच्चे पैदा कर सकने वाला शरीर}

सारांशः इस अभ्यास की मदद से युवकों को अपने एवं स्त्रियों के शरीर के बारे में गलत धारणाओं के बारे में पता चलेगा जिससे कि वह अपने स्वास्थ्य एवं शरीर की अच्छी तरह से ध्यान रख सकते हैं।

उद्देश्यः युवकों को पुरुष एवं स्त्रियों के प्रजनन तंत्रों की जानकारी देना। किसी भी प्रतिभागी की भ्रांतियों का निवारण करना और अपने शरीर की देखभाल करने का अहसास कराना।

समय : 2 घंटे

सामग्री :

- कोरे कागज, पेन्सिल

- स्त्री और पुरुष के अंदरूनी तथा वाह्य प्रजनन अंगों के नाम तथा रेखाचित्र।

- पुरुष और स्त्री के प्रजनन अंगों के रेखाचित्र।

प्रक्रिया

- पुरुष एवं स्त्री के अंगों के नाम अलग-अलग कार्डों पर लिखें, एक कार्ड पर केवल एक अंग का नाम लिखें। इन कार्डों को एक बैग में एक साथ मिलाकर रखें।

- सभी सहभागियों को दो समूहों में विभाजित करें।

- दोनों समूहों में से हर एक प्रतिभागी को बैग से एक कार्ड उठाना होगा, उस कार्ड पर पुरुष या स्त्री के जिस अंग का नाम लिखा होगा, उस अंग के बारे में, बिना बोले या बिना उस अंग की तरफ इशारा किए, अपने हाव-भाव से अन्य सदस्यों को इस अंग के बारे में बताने का प्रयास करना होगा। समूह के अन्य सदस्यों को इन हाव-भावों की मदद से अंदाजा लगाना होगा
कि, वह कौन सा अंग है। जो समूह हाव-भाव से सही नाम बता पाएगा, उसे अंक मिलेंगे, और जो गलत बताएगा उस समूह के अंक कम होंगे। ध्यान में रहे कि, सिर्फ अपने हाव-भाव से व्यक्त करने का प्रयास करें, न कि शरीर के किसी अंग की ओर इशारा करें। अगर ऐसा होता है तो अंक कम होंगे या फिर काट दिए जायेंगे।

- कौन सा समूह पहले खेलेगा इसके लिए टॉस करें। बैग में रखे सभी कार्ड, खत्म होने तक खेलते रहें।

- अगर सहभागियों की समझ में नहीं आता है तो प्रेरक उन्हें एक कार्ड निकालकर अपने हाव-भाव से उस अंग के बारे में बताने का प्रयास करें।

- दोनों समूहों का स्कोर बोर्ड बनाएं और इस दौरान उनके द्वारा पहचाने गए अंगों के नाम लिख लें। 
- इस कार्याभ्यास के द्वारा सामने आयी बातों में से ध्यान रखने योग्य बातें बतायें। जैसेः आपसी मेल-जोल, स्पर्धा आदि।

\section{अभ्यास के पहले ये नियम दोनों समूहों को बता देने चाहिए}

\section{चर्चा के मुद्दे}

- पहचानने में सबसे कठिन अंग कौन से हैं?

- इनमें से कौन से अंग आपको पहले से मालूम थे?

- क्या पुरुष के बाहरी और अंदरूनी प्रजनन अंगों के नाम और उनकी उपयोगिता के बारे में जानकारी होना जरूरी है? और क्यों?
- क्या इन सब बातों की जानकारी पुरुषों को होती है? अगर हां तो कैसे? अगर नहीं तो क्यों नहीं होती?

- कुछ पुरुष ऐसा क्यों सोचते हैं कि, चूंकि पुरुष बच्चे नहीं पैदा करता इसलिए उसे शरीर की जानकारी की जरूरत ही नहीं है?

- क्या लिंग, योनि, स्त्रियों का मासिक धर्म, गर्भाशय इत्यादि शरीर के अंगों पर विस्तार से चर्चा होनी चाहिए?

- अपने लिंग की देखभाल पुरुषों को किस प्रकार करनी चाहिए? और, रत्री को अपनी योनि की देखभाल किस प्रकार करनी चाहिए?

- स्त्री और पुरुष में से किस के जननांगों को समझने में अधिक कठिनाई होती है? और क्यों?

\section{अंत में}

- स्वयं के शरीर के बारे में अधूरा और मर्यादित ज्ञान होने के नुकसान समूह को बताइये।

- पुरुष एवं रत्री के प्रत्येक अंग के क्रियाकलापों के बारे में जानकारी दें। यह भी बताएं कि जननांग अलग-अलग आकार एवं नाम के होते हैं।

- यौन संबंधों से फैलने वाली बीमारियों के बारे में जानकारी दें।

- यह भी बताएं कि अलग-अलग नाम के होने के बावजूद वे सेक्स की संतुष्टि को प्रभावित नहीं करते।

- शुक्राणु कैसे तैयार होते है? और बच्चा पैदा करने के संदर्भ में शुक्राणुओं का क्या संबंध है? इस पर चर्चा करें।

- जननांगों की देख-रेख में पुरूषों की भूमिका पर जोर दें।

- साथ में दी गयी संसाधन पत्रक का प्रयोग कों।

\section{संसाधन पत्रक: पुरुष के बाहरी प्रजनन अंग}

- लिंगः मूत्र-पेशाब और प्रजनन करने वाला अंग। यह अंग संवेदनशील होता है। हर पुरुष में इस अंग का आकार अलग-अलग हो सकता / होता है। आमतौर पर यह अंग ढीला और मुलायम होता है। यौन उत्तेजना होने पर इसकी मांस पेशियों में खून का प्रवाह बढ़ जाता है। जिसकी वजह से लिंग का आकार बढ़ता है, वह सीधा हो जाता है, इसे लिंग का उत्तेजित होना कहते हैं। संभोग के दौरान जब लिंग बहुत उत्तेजित होता है तब उसमें से वीर्य बाहर आता है, जिसमें कि शुक्राणु होते हैं। वीर्य बाहर निकलते समय परम
सुख का अनुभव मिलता है। इसी को संभोगसुख या रतिसुख कहते हैं।

- अंडु/पोते (स्क्राटम): लिंग के पीछे, निचले स्तर पर थैली की तरह एक अंग होता है। उसमें अनेक पेशियों के स्तर होते हैं। बाहरी स्तर पर बालों से लिपटी मुलायम चमड़ी होती है। इन बालों का रंग शरीर के अन्य बालों की तुलना में ज्यादा गहरा होता है। थैली के खिंची हुई (संकुचित) या खुली हुई अवस्था के अनुसार उसका रूप, आकार बदलता है। सर्दियों में यह थैली खिंची हुई होती है और उस पर झुर्रियां आ 
जाती हैं। गर्मी के मौसम में यह थेली खुली और नर्म होती है। अण्डकोष में ही अण्डू होते हैं।

- लिंग की टोपी और खुली चमड़ी: लिंग उत्तेजित होने पर यह चमड़ी पीछे जाती है। जिसकी वजह से लिंग का सिर खुल जाता है। अगर वह चमड़ी पीछे नहीं जाती तो संभोग के समय दर्द होता है। यदि यह चमड़ी पीछे न जाए तो शरीर की साफ-सफाई रखने में भी तकलीफ होती है। इस स्थिति को फिमोसिस कहते हैं। लोकल एनेस्थिशिया की मदद से एक छोटी सी शल्य क्रिया के द्वारा पीछे न जाने वाली चमड़ी को ठीक किया जाता है। कुछ देशों में, समाज और परिवार में छोटे लड़कों के लिंग की टोपी की चमड़ी निकाल देते हैं, जिसे 'खतना' कहते हैं।

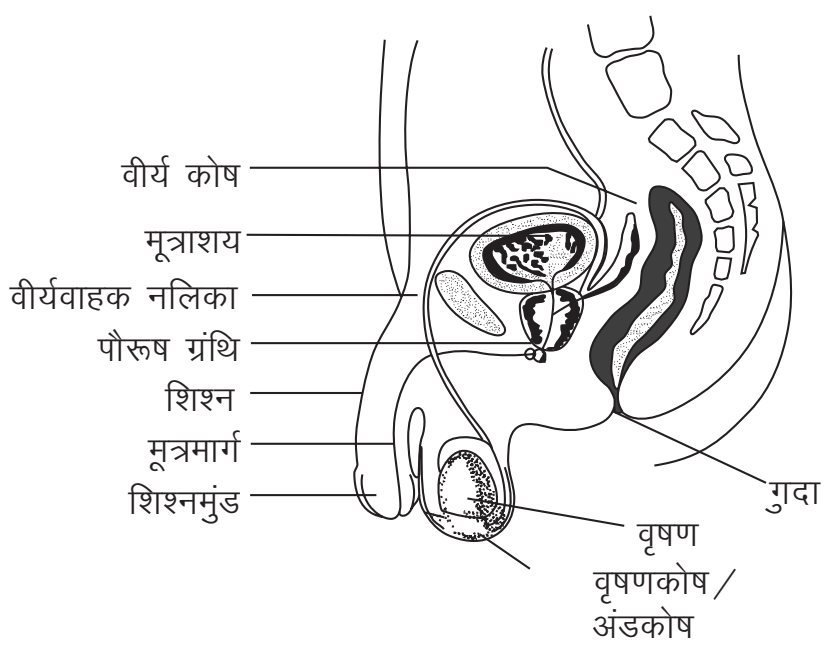

\section{पुरुष के अंदरूनी प्रजनन अंग}

अण्ड ग्रन्थियां (टेक्टिकल्स)- पुरुषों की यौन पेशियां, हार्मोनों तथा शुक्राणुओं को तैयार करने का मुख्य कार्य इनका होता है। टेस्टेस्टोरॉन नामक एक हार्मोन है जो चमड़ी का रंग, बाल, आवाज और स्नायु की रचना को निर्धारित करता है, जिससे पुरुष की पहचान होती है। यह अण्डकोष अंडों के आकार के होते हैं। हाथ से दबाने पर हमें इसका अनुभव होता है।

- मूत्र नलिका (यूरेथा) - इस नली के द्वारा शरीर का पेशाब बाहर आता है। इसी नलिका के माध्यम से वीर्य भी बाहर निकलता है। इस नली की लंबाई 20 से.मी. रहती है। इसके मुख्य तीन भाग होते हैं।
- प्रोस्टॅटिक युरेश्रा: प्रोस्टेट पेशियों में जाने वाली नलिका।

- मेमब्रेनस युरेथा: जांघ के मध्य भाग से पेट में जाने वाली नलिका।

- ट्रॉव्हरसेस: लिंग के सिर तक जाने वाली नलिका।

एपिडीमियसः अण्डकोषों को जोड़ने वाली नलिका। अण्डकोष में शुक्राणु तैयार होते हैं, वो ठीक तरह से बढ़ने तक इस नलिका में रखे जाते हैं। यहां से वह वीर्य के साथ बाहर निकाल दिये जाते हैं।

वीर्य वाहिनी (सेमिनल व्हेसिकल्स): शुक्राणुओं के बहाव के माध्यम से द्रव पदार्थ तैयार करने वाली दो थैलियां।

अतिसूक्ष्म नलिकाएं (डेफरेन्ट डक्ट): अण्डकोषों से लेकर प्रोस्टेट पेशियों तक शुक्राणुओं को प्रवाहित करने वाली अतिसूक्ष्म नलिकाएं।

उत्सर्जित नलिका (इजेक्यूलेटरी डक्ट): सेमिनल व्हेसिकल्स और डिफरेंट डक्ट्स, इन दो नलिकाओं के आपसी संगम से तैयार हुई नलिका। यह नलिका छोटी और सीधी होती है। ज्यादातर लंबाई प्रोस्टेट के बाजू से आती है। यह युरेश्रा (मूत्रनलिका) के पास आकर खत्म हो जाती है। सेमिनल व्हेलिसकल्स और डिफरंट डक्टस के द्रव्य पदार्थ इस नलिका से होते हुए एक साथ प्रॉस्टॉलिक युरेथ्रा में पहुंच जाते हैं।

\section{स्त्री के बाहरी प्रजनन अंग}

योनि (मॉस हेनस) : मॉस व्हेनस जांघ के प्युबिस नाम की हड्डी पर गोल सा एक भाग होता है। बड़ी उम्र की औरतों में इस भाग पर बाल आते हैं। इन बालों की वजह से इस भाग का संरक्षण होता है।

लैबिया मेजोराः छोटे-छोटे बालों से ढके हुए भग/होंट, जो मॉस व्हेनस तक फैले होते हैं।

लैबिया मायनोरा: इन पर बाल नहीं होते, होंठों के आकार का चमड़ी का वह भाग जो बाहरी योनि अंग को थोड़ा खींचने पर दिखाई देता है। यह अंग अति संवेदनशील 


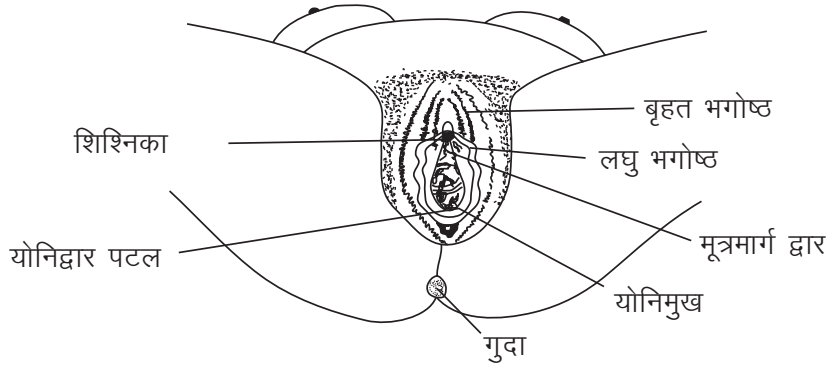

होता है और उत्तेजित होने पर इसका आकार बड़ा हो जाता है।

भग्नाशय (क्लिटोरिस): यह दाने जैसा छोटा अंग है, जो स्त्री के संभोग सुख के दृष्टिकोण से बहुत महत्वपूर्ण है। यह अति संवेदनशील होता है। स्त्री जब उत्तेजित नहीं होती है तब इसे स्पर्श करने पर उसे बहुत तकलीफ होती है लेकिन धीरे-धीरे और हल्के से स्पर्श करने पर स्त्री को सुख का अनुभव होता है। इसी को स्त्री का संभोग सुख कहते हैं।

पेशाब नली का मुंह: (ओपनिंग ऑफ दी यूरेथा): पेशाब नली का मुंह। इसमें से पेशाब/मूत्र बाहर आता है।

योनिद्वार (ओपनिंग ऑफ दी वैजाइना): लंबे आकार का मुंह, इसमें से मासिक धर्म का खून और प्रसव के समय बच्चा बाहर आता है।

\section{स्त्री के भीतरी जननांग}

गर्भाशय: पेट से रहने के समय, गर्भ बढ़ने की जगह। जब स्त्री गर्भवती नहीं होती तब उसका गर्भाशय मुट्ठी के आकार का होता है।

गर्भाशय का मुंह: इसमें एक छिद्र होता है। इस छिद्र में से मासिक धर्म के समय द्रव पदार्थ बाहर निकलता है। इसी मार्ग से शुक्राणु अंदर जाता है। आमतौर पर गर्भ के समय इस छिद्र का आकार बढ़ जाता है तथा प्रसव के लिए यह बड़ा हो जाता है।

\section{गर्भाशय का अंग}

गर्भाशय का अंग गर्भ के समय बड़ा होता है और बच्चा पैदा होने के बाद छोटा हो जाता है। इस पर दो बाहरी
स्तर होते हैं। पेरटोनियम नाम की झिल्ली (मेम्ब्रेन) जिसे हम जाली भी कहते हैं, वह और मायोमेट्रीयम नाम की पेशियों का एक स्तर होता है। गर्भाशय के अंदर से एन्ड्रोमेट्रीयम नाम की झिल्ली (मेम्ब्रेन) या जाली जैसे चमड़ी का आवरण होता है। मासिक धर्म के समय यह वहां से निकलकर बाहर आता है और हर महीने नया आवरण यहां पर तैयार होता है।

फेलोपियन ट्यूब्स: यह गर्भाशय के दोनों ओर उपस्थित यह रत्री बीज पेशी, अण्डोत्सर्ग के पास आने पर फूलों की पंखुड़ी की तरह खुलती है। इन नलिकाओं में से ओवम या स्त्री बीज, गर्भाशय की ओर जाते हैं।

डिम्ब ग्रंथि (ओवरीज) : यह बादाम के पत्ते के आकार की होती हैं। गर्भाशय के दोनों तरफ दो ग्रंथियां गर्भाशय के साथ, मज्जातंतु और चमड़ी के अनेक स्तरों से जुड़ी हुई होती है। कोई स्त्री अपने सम्पूर्ण जीवन में इस पेशी द्वारा लगभग 5 लाख अंडे तैयार कर सकती है। ये पेशियां हार्मोनों का भी निर्माण करती हैं।

योनिमार्ग (वैजाइना): योनिमुख से लेकर गर्भाशय के मुख तक जाने वाला मार्ग। हमारे मुंह की पेशियों की तरह, अनेक मांसपेशियों से यह मार्ग बना हुआ होता है। इसमें अलग-अलग स्तर होते हैं। यह स्तर संभोग के समय या बच्चा बाहर आने के समय योनिमार्ग के आकार को बड़ा बनाने में सहायता करते हैं। इस योनिमार्ग में लिंग का प्रवेश होने पर कुछ स्तियों को आनंद मिलता है और कुछ स्त्रियों को नहीं। अधिकतर स्त्रियों को दाने (भग्नाश्य) को स्पर्श करने से ज्यादा सुख और आनंद मिलता है।

\section{मासिक धर्म/माहवारी}

महिलाओं में 12 से 50 की उम्र तक हर महीने स्त्री की योनि से खून का बहाव होता है जिसे मासिक धर्म/माहवारी कहते हैं।

मासिक धर्म हर 28 दिनों के बाद होता है। यह नियम होते हुए भी यह 21 से 35 दिनों में भी आ जाए तो इसे सामान्य ही मानते हैं। यह खून का बहाव, 3-4 दिनों तक होता है। 2 से 7 दिनों तक का बहाव स्वाभाविक माना जाता है। मासिक धर्म का बहाव स्त्री की योनि से 


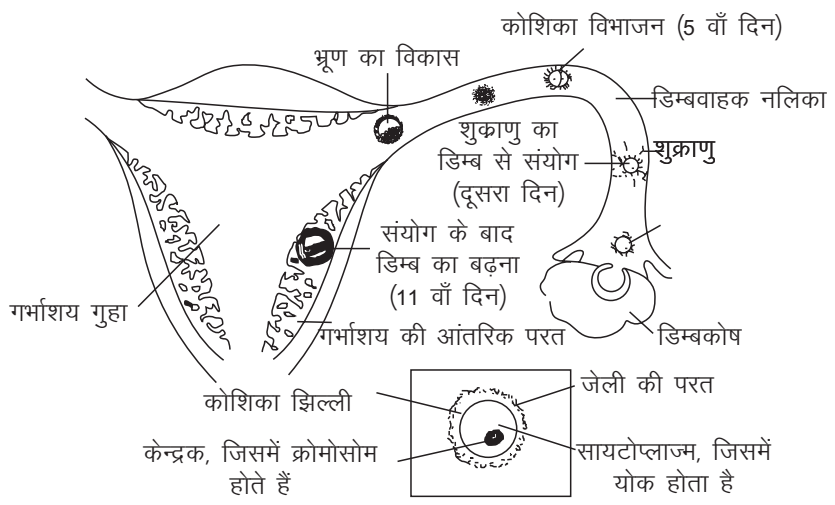

शरीर के बाहर आता है। यह गर्भाशय में तैयार होता है। इस बहाव में खून और श्लेष्मा का मिश्रण होता है। यह बहाव रोकने के लिए स्त्री कपड़ा या सेनेटरी पैड योनिद्वार पर रखती है। पैड में रुई की पर्तें होती हैं।

\section{यह स्राव कैसे आता है?}

जीवन के 12 वें साल के दौरान लड़कियों के शरीर में एक महत्वपूर्ण घटना घटती है। दिमाग में पिटयुटरी ग्रंथि में से हार्मोनों का बहाव होता है। उसके कारण स्त्री बीज ग्रंथियां सक्रिय हो जाती हैं। स्त्री बीज ग्रंथि में इस्ट्रोजन
और प्रोजेस्टेरॉन हार्मोन तैयार होते हैं। इन हार्मोंनों के कारण स्तन का बढ़ना, मासिक धर्म आना, गर्भधारण, प्रसूति इत्यादि क्रियाएं होती हैं। लड़की जब सयानी होती है तो, स्त्री बीज ग्रंथि में से एक अण्डा परिपक्व होकर बाहर निकलता है। इस्ट्रोजेन और प्रोजेस्टेरॉन हार्मोनों के कारण गर्भाशय में एक तरह की सतह तैयार होती है। अगर स्त्री को गर्भधारण होता है (स्त्रीबीज- और शुक्राणु का मिलन) तो यह फलित स्त्रीबीज इसी सतह से चिपक जाता है और वहीं पर पोषण प्राप्त कर भूण में रूपांतरित होता है। अगर उस महीने में नया बीज फलित नहीं हुआ हो तो इस सतह का उपयोग नहीं होता है। इस कारण वह गिर जाता है और यह स्राव के रूप में योनि से बाहर निकलता है। अगले महीने में नया स्त्री बीज परिपक्व होता है। उसके स्वागत के लिए फिर एक बार नयी सतह तैयार होती है। अगर शुक्राणु के संयोग से स्त्री बीज फलित हुआ हो (सत्री पेट से रही) तो यह सतह नहीं बिखरती है, क्योंकि इसी सतह के द्वारा स्त्री बीज विकसित होता है। इस कारण से प्रसूति तक स्त्री को माहवारी नहीं आती है। प्रसूति के बाद कुछ महीनों में फिर से नया स्त्री बीज परिपक्व होने लगता है। गर्भाशय में फिर से सतह तैयार होने लगती है और माहवारी शुरू हो जाती है। 
अभ्यास 2.4

\section{यौन आकुलताः हो सके तो, जवाब दो...}

सारांशः यह अभ्यास पुरुषों के प्रजनन/स्वास्थ्य एवं उससे संबंधित शारीरिक देखरेख के बारे में जानकारी देता है। साथ में पुरुषों एवं स्त्रियों के यौन व्यवहारों तथा उनसे जुड़े मूल्यों की भी चर्चा करता है। समाज में पुरुष होने का क्या तात्पर्य है? इसकी चर्चा भी की गयी है।

उद्देश्यः इस बात की चर्चा करना कि युवा वर्ग की लैंगिकता और प्रजनन स्वास्थ्य के बारे में क्या दृष्टिकोण, विचारधारा एवं मान्यताएं हैं?

समयः 1 घंटा

सामग्री: गुब्बारे, सवाल लिखे हुए कागज।

\section{प्रक्रिया}

- सभी प्रतिभागियों को एक बड़े गोल दायरे में बैठने के लिए कहें।

- फिर उनसे कहें कि उसी गोले में, वह एक गुब्बारा एक दूसरे को देने वाले हैं।

- पहले से ही सवालों से भरे गुब्बारे तैयार रखें। एक गुब्बारे में एक सवाल रखें।

- अच्छी सहभागिता के लिए टेप रेकार्ड पर अच्छा सा गाना बजाएं तथा गाने की ताल पर गुब्बारा एक दूसरे को पास करने को कहें।

- बीच में जहां गाना रुक जाए या जब किसी को रोकने के लिए कहें, तब जिसके हाथ में वह गुब्बारा हो, उसे गुब्बारा फोड़कर अंदर से कागज पर लिखे गये सवाल को जोर से पढ़ने और उसका जवाब देने को कहें।

- अगर वो व्यक्ति जवाब नहीं दे सकता तो उसके दांये या बांए वाले व्यक्ति को जवाब देना जरूरी है।
- बाकी सभी प्रतिभागी जरूरत पड़ने पर सवाल का जवाब देने में मदद कर सकते हैं।

- उस सवाल का जवाब देने पर यह खेल फिर से शुरू होगा, फिर से गाना बजेगा। जब तक कि सभी सवाल खत्म नहीं हो जाते तब तक खेल जारी रहेगा।

सवाल

1. हस्तमैथुन क्या है?

2. हस्तमैथुन की वजह से लिंग छोटा हो जाता है? क्या यह सही है?

3. अपने लिंग को कैसे धोया जाए?

4. किसी पुरुष को किस प्रकार की यौन समस्याएं हो सकतीं हैं? और क्यों?

5. अपने अंडाशय में होने वाले कैंसर से बचने के लिए आप किस प्रकार की शारीरिक जांच करवा सकते हैं? 
6. लिंग में होने वाले कैंसर से बचने के लिए आप किस प्रकार की शारीरिक जांच करवा सकते हैं?

7. प्रॉस्ट्रेट ग्रंथियों में होने वाले कैंसर से बचने के लिए आप किस प्रकार की शारीरिक जांच करवा सकते हैं?

8. सेक्स के दौरान पुरुष को किस बात का सबसे ज्यादा डर लगता है?

9. सेक्स के दौरान पुरुषों को किस तरह की परेशानियां होती हैं?

10. जल्दी से वीर्यपतन (शीघ्रपतन) से बचने के लिए पुरुष क्या कर सकते हैं?

11. नींद में कभी-कभी पुरुष का वीर्य पतन क्यों हो जाता है?

12. पुरुष को कैसा लगता है जब कोई उसे कहता है कि तुम्हारा लिंग छोटा है? वह कैसे तथा किस तरह की प्रतिक्रिया देता है, और क्यों?

13. क्या लिंग का आकार सचमुच मायने रखता है? क्यों?

14. पुरुषों को स्त्रियों की तुलना में ज्यादा सेक्स की जरूरत होती है? आपकी इस बारे में क्या राय है?

15. पुरुष अपने लिंग के बारे में क्या सोचते हैं?
16. क्या पुरुष अपने सेक्स पर नियंत्रण रख सकता है? आपकी क्या राय है?

17. आप ब्लू फिल्म में दिखाये गये सेक्स के बारे में क्या सोचते हैं? क्या वह संभव है? यदि हां तो कैसे, यदि नहीं तो क्यों नहीं?

इस ढंग के और भी सवाल हो सकते हैं।

\section{चर्चा के मुद्दे}

- आपकी राय में पुरुष होने का क्या मतलब है?

- पुरुष को अपने शरीर की देखभाल कैसे करनी चाहिए?

- क्या लिंग का आकार पुरूष के लिए महत्वपूर्ण है और क्यों?

- सेक्स विशेषज्ञ (सेक्सोलॉजिस्ट) के पास जाना कुछ पुरुषों के लिए क्यों कठिन होता हैं?

- यौन बीमारियों से बचने के लिए पुरुष कौन से अवरोधक उपाय अपनाते हैं?

- पुरुष अपने आपको यौन संबंधों द्वारा फैलने वाले गुप्त रोगों और एचआईवी तथा एड्स से कैसे बचा सकते हैं?

\section{अंत में}

- हमारे समाज में पौरूष के बारे में परम्परागत विचारों से मर्द एवं उनके व्यवहार परिभाषित होते हैं। अपने पौरूष को साबित करने के लिए बहुत से युवक या पुरुष जोखिम भरे व्यवहारों में सहभागी बनते हैं। परिणामतः वे अलग-अलग चिंताओं, बीमारियों से परेशान होते हैं। व्यसनाधीनता से जीने की इच्छा खो बैठते हैं। अगर हम मृत्यु दर और बीमारी की दरों पर विचार करें तो पायेंगे कि औरतों की तुलना में पुरुषों की मृत्यु दर ज्यादा है। अधिकतर दुर्घटनाएं बहुत से देशों में पुरुषों द्वारा ज्यादा शराब और नशीली चीजों का सेवन करने के कारण होतीं हैं।

- इसके बारे में पहले भी चर्चा की जा चुकी है लेकिन यहां पर दुबारा इसका जिक्र किया जा सकता है। इसके साथ ही इस पर भी गंभीरतापूर्वक चर्चा करें कि पुरुष किसी भी जोखिम भरे माहौल में सेक्स करने के लिए तैयार रहता है। 


\section{संसाधन पत्रक}

\section{1. अंडाशय में होने वाले कैंसर से बचने के उपायों का परीक्षण}

पुरुषों के अंडाशय को होने वाले कैंसर पर अलग से विचार करें तो यह पुरुषों में होने वाले सभी प्रकार के कैंसरों का मात्र एक प्रतिशत है, और यह 15 से 35 सालों के बीच पुरुषों में पाया जाने वाला सामान्य कैंसर है। सामान्य तौर पर यह पुरुषों के अंडाशय में पाया जाता है और एक बार निकाल देने के बाद पुरुष की लैंगिक और प्रजनन क्रिया में कोई फर्क या परेशानी नहीं होती है। अंडाशयों के कैंसर के बारे में शुरुआती स्तर पर ही पता चल जाये, तो उसे पूरी तरह से, आसानी से ठीक किया जा सकता है।

इसके आमतौर पर नजर आने वाले लक्षणः मटर की आकार जैसी गांठ अंडाशय में बनती है, जिसमें कि दर्द नहीं होता है।

\section{परीक्षण कैसे करें?}

स्वतः परीक्षण महीने में एक बार अवश्य करें। गर्म पानी से नहाएं। नहाने के बाद गर्माहट की वजह से त्वचा या चमड़ी मुलायम होती है। अंडाशय की चमड़ी ज्यादा मुलायम और हल्की हो जाती है। हम यहां पता कर सकते हैं कि अंडाशयों के आकार में किसी प्रकार की गड़बड़ी तो नहीं है? इसलिए बड़े आइने के सामने खड़े होकर दोनों हाथों से अपने अंडाशयों की जांच करें। बीच वाली उंगली और बाकी उंगलियां अंडुवे के नीचे ऊपर रखकर जांच करें जैसे कि-

i. हल्के से दोनों अंडुओं को उंगलियों और अंगूठे के बीच घुमाएं और यह पता करने की कोशिश करें कि अंडाशय मुलायम है या कठोर। अंडुओं के पीछे एक नलिका होती है, उसे भी हल्के से जांच लें।

ii. दोनों अंडुओं के आकार को भी जांच लें। वे साधारण स्थिति में हैं या नहीं, यह सामान्य बात है कि, एक अंडु का आकार दूसरे अंडु के आकार से थोड़ा बड़ा हो सकता है।
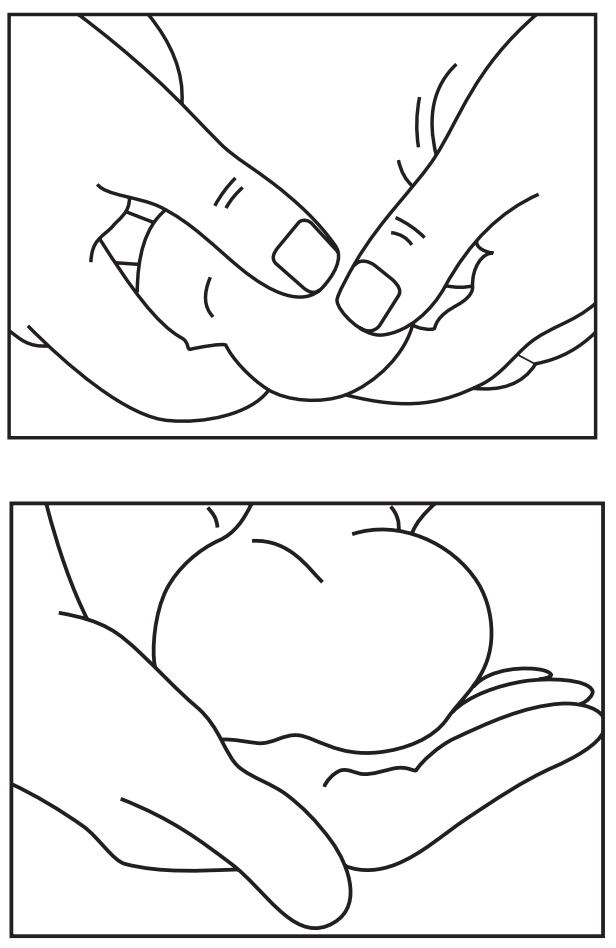

iii. अगर किसी भी प्रकार की गांठ दिखायी दे तो तुरंत डाक्टर को दिखाना आवश्यक है। ऐसी गांठ साधारण तौर पर अंडु के दोनों ओर नजर आती है लेकिन कभी-कभी यह सामने वाली दिशा में भी पायी जाती है। सभी गांठ कैंसर की गांठ नहीं होतीं, अगर गांठ कैंसर की होती है और उसका इलाज न किया जाए तो वह बहुत जल्द पूरी तरह फैल जाती है।

\section{2. लिंग मे होने वाले कैंसर से बचने के उपायों का परीक्षण}

स्वास्थ्य के प्रति आना-कानी या स्वास्थ्य की ओर ध्यान न देना यह लिंग के कैंसर का सबसे बड़ा कारण है। हालांकि, इसे रोकने की सबसे पहली सीढ़ी अपने लिंग को रोजाना साबुन और पानी से अच्छी तरह धोना, साफ करना साथ ही साथ यौन संबंध, और हस्तमैथुन के बाद भी अच्छी तरह धोना और साफ करना चाहिए। प्राथमिक स्तर पर पता चलने पर लिंग के कैंसर का पूरी तरह से इलाज किया जा सकता है, और वह ठीक हो सकता है। 
अगर देर से पता चले और समुचित इलाज न किया जाये तो यह पूरे लिंग तथा प्रजनन अंगों में फैल सकता है। इस कारण मौत भी हो सकती है। जिसका स्वरूप बहुत ही भयानक हो सकता है।

लिंग का स्व:परीक्षण

पुरुष द्वारा हर महीने में एक बार अपने लिंग को अच्छी तरह से जांच लेना आवश्यक है, क्योंकि ऐसे जख्म जो इलाज करने के बाद भी ठीक नहीं होते, गांठ जो इलाज करने के बाद भी नहीं जाती, और जिसमें से पीप और गंदी बदबू आती है यह सभी लक्षण कैंसर की तरफ इशारा करते हैं। इसलिए इसका परीक्षण करना आवश्यक होता है।

फिमोसिस से ग्रस्त व्यक्तियों में गांठें ठीक होने जाने के बाद भी प्रभावित क्षेत्र में लम्बे समय तक लालामी तथा जलन रह सकती है एवं सफेदी झड़ना तथा गुप्तांगों के आस-पास फोड़े फुंसी हो सकते हैं।

यह लक्षण आमतौर पर वयस्कों में पाया जाता हैं इनमें से एक भी लक्षण दिखायी दे तो तुरन्त डाक्टर से मिलकर सलाह लेना आवश्यक है और भी एक महत्वपूर्ण सलाह यह है कि, साल में एक बार युरोलॉजिस्ट को दिखाकर पूरी तरह जांच अवश्य करवा लेनी चाहिए।

\section{3. प्रोस्टेट (मूत्राशय के ऊपरी हिस्से पर होने वाली ग्रंथि)}

इन ग्रंथियों में होने वाले कैंसर से बचने के उपायों का परीक्षण। पुरुष के वीर्य में 30 प्रतिशत हिस्सा प्रोस्टेट ग्रंथियों द्वारा निर्मित द्रव का होता है। 40 साल की आयु के बाद पुरुष द्वारा अपनी प्रोस्टेट ग्रंथियों की नियमित रूप से जांच करना आवश्यक है। आमतौर पर यह लक्षण कुछ पुरूषों में 50 वर्ष या उससे अधिक उम्र में दिखायी देते हैं जैसे कि पेशाब करने में तकलीफ होना, बार-बार जुलाब होना, बहुत कम पेशाब होना और मूत्राशय पूरी तरह से भरा है ऐसा एहसास होना इत्यादि। यह परिणाम/लक्षण, प्रोस्टेट ग्रंथियों के आकार में बदलाव होने के कारण या उसकी मांसपेशियां बड़ी होने के कारण दिखायी देते हैं। जिसके कारण मूत्रमार्ग संकुचित होता है और पेशाब की क्रिया में दिक्कत आती है। यह लक्षण

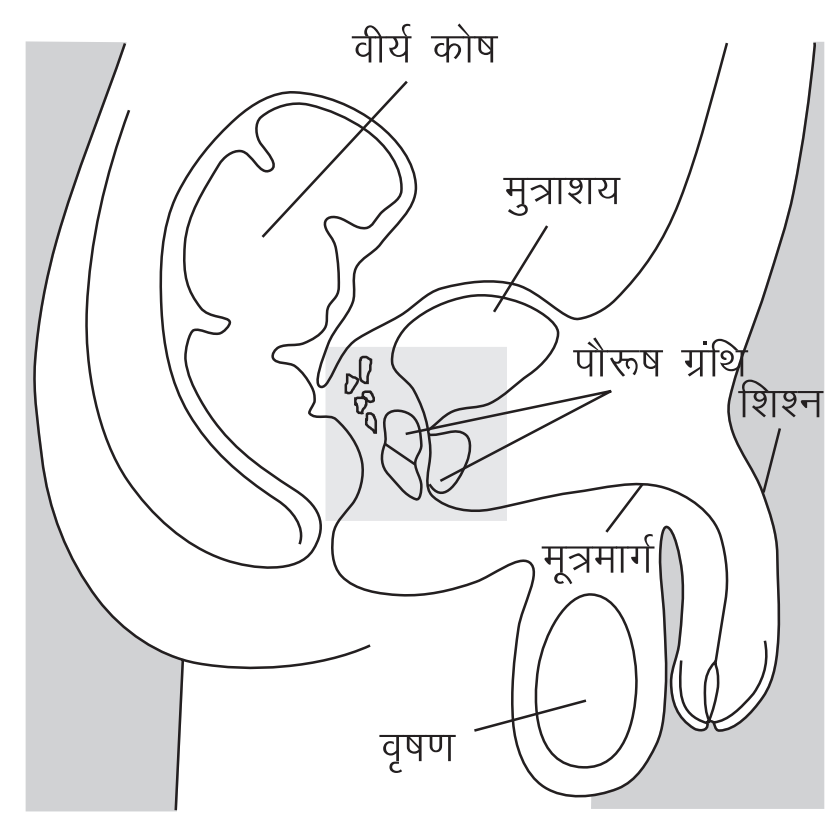

प्रोस्टेट हाइपरप्लासिया की शुरूआत कहे जाते हैं। लेकिन अब इसे रोकने के सबसे अच्छे तरीके उपलब्ध हैं। इस इलाज के बहुत से तरीके हैं- जैसे कि दवाइयां, प्रभावित अंग की सिकाई, भाप-विधि, दूरबीन तथा पारम्परिक शल्य क्रिया इत्यादि।

इसके बारे में एक युरोलॉजिस्ट (ऐसे डाक्टर जो पुरुष के यौन अंगों की विशेष रूप से जांच करते हैं) ही अच्छी तरह सलाह दे सकता है। अगर इसे बिना इलाज किए छोड़ दिया जाए तो प्रोस्टेट ग्रंथियों में आयी हुई सूजन और भी खतरनाक हो सकती है। मूत्राशय में संक्रमण हो सकता हैं पेशाब में पूरी तरह से रुकावट आ सकती है, या मूत्रपिंड खराब हो सकता है। प्रोस्टेट कैंसर यानि कि प्रोस्टेट ग्रंथियों में अनियंत्रित पेशियों का बढ़ना। यह 50 की आयु के बाद 12 में से एक आदमी को होता है। सामान्य तौर पर इसके लक्षण तभी दिखायी देते हैं जब यह पूरी तरह विकसित होता हैं जैसे कि पेशाब में खून और दर्द होना। हम इसे नियंत्रित कर सकते हैं या नहीं यह उसका परीक्षण करने के बाद ही बताया जा सकता है। परीक्षण करने से प्रोस्टेट कैंसर ठीक होने की संभावना बढ़ती है।

प्रोस्टेट कैंसर से बचने के उपायों के परीक्षण के तीन प्रकार हैं।

अल्ट्रा साउण्ड तथा खून की जाँच एवं स्पर्श विधि इत्यादि परीक्षण का सबसे आसान तरीका स्पर्श विधि है। 
इसमें डाक्टर गुदाद्वार में उंगली डालकर प्रोस्टेट के आकार और इसकी घनत्व की जांच करते हैं।

\section{4. यौनिक अकार्यक्षमता}

जब कभी भी एक पुरूष या औरत संभोग के दौरान कोई भी शारीरिक या मानसिक कठिनाई महसूस करते हैं : जैसे कि - पुरूष के लिंग का खड़ा न होना, या सेक्स के दौरान बहुत जल्द वीर्यपतन होना, या किसी औरत को यौन क्रिया की इच्छा न होना, सेक्स के परमोच्च बिंदु तक न जाना आदि। यह अकार्यक्षमता जैविक कारणों से होती हैं। जैसे कि : मधुमेह, दवाईयों के दुष्परिणाम, नशीली चीजों का इस्तेमाल आदि। इसके अलावा मानसिक कारण भी होते हैं जैसे कि नकारात्मक या दबाव से भरा पालनपोषण, यौन क्रिया के सहयोग को लेकर चिंतायें,
दो साथियों के बीच तनाव, पिछला निराशाजनक एवं भयानक अनुभव, तथा तनाव/अवसाद इत्यादि।

\section{सामान्य तौर पर पुरूषों में निम्नलिखित यौन अकार्यक्षमता} होती है।

1. लिंग उत्तेजित न होने के संदर्भ में - जब पुरुष का लिंग ठीक तरह से उत्तेजित नहीं होता है तब यह दो प्रकार की अकार्यक्षमता हो सकती है। प्राथमिक स्तर- पुरुष लिंग का कभी भी उत्तेजित नहीं होना, द्वितीय स्तर- पहले लिंग उत्तेजित होता था पर अब नहीं होता।

2. जल्दी वीर्यपतन होना - योनि में प्रवेश करने से पहले ही वीर्यपतन होना, या योनि में प्रवेश के तुरंत बाद वीर्यपतन होना।

3. वीर्यपतन में रुकावट- पुरुष का कभी भी वीर्यपतन नहीं होना। 
उद्देश्य : युवा वर्ग में पति-पत्नि/साथी के बीच प्रजनन संबंधित बातचीत की महत्ता को बतलाना। साथ ही साथ लिंग जाँच और उसके परिणामों के बारे में चर्चा करना।

\section{अनुमानित समय : 1 घन्टा}

सामग्री : सभी समूहों के लिए कहानियों कि प्रति, सभी के लिए पेन या पेन्सिल।

शुरू करने के निर्देश : ऐसा बहुत कम ही होता है जब हम युवाओं के साथ, पति-पत्नि के बीच गर्भ धारण, गर्भ निरोधक, माहवारी इत्यादि के संबंध में होने वाले बातचीत की उपयोगिता के बारे चर्चा करते हैं। इस अभ्यास के द्वारा प्रेरक समूह के लोगों को इस बात के लिए जागरूक करेंगे कि पति-पत्नि के बीच उपरोक्त बातचीत एक सफल एवं स्वस्थ जीवन के लिए अतिआवश्यक है।

विधि

1. प्रतिभागियों को 5-6 सदस्यों के विभिन्न समूह बनाने को कहें।

2. यह बतायें कि उन्हें एक छोटी कहानी पढने को दी जाएगी और इससे संबंधित चर्चा बाद में की जाएगी।

3. यह भी बतायें कि कहानी के तीन भाग हैं, जब समूह एक भाग समाप्त कर लेंगे तो उन्हे दूसरी कहानी दी जाएगी।

4. जब सभी का कहानी पढना समाप्त हो जाऐ तब इससे संबंधित प्रश्नो पर चर्चा की जाएगी जिसे समूह का एक सदस्य जवाब देगा।

\section{चर्चा के प्रश्न}

- एक दम्पत्ति के लिए कौन-कौन से विकल्प हैं अगर पत्नि गर्भवती हो जाती है तो?

- अगर पत्नि गर्भवती हो जाती हैं तो उसके पति की क्या प्रतिक्रिया होगी? पत्नि की क्या प्रतिक्रिया होगी?

- अगर किसी युवा पुरूष को यह मालुम हो जाए कि वह पिता बनने वाला है तो उसकी सोच क्या होगी। 
42

यारी दोस्ती

अंत में

- इस बात को जानने की कोशिश की जानी चाहिए कि युवाओं में गर्भधारण से संबंधित नजरिया, सोच इत्यादि क्या है।

- इस बात पर भी चर्चा करें कि युवाओं को यह मालूम होना चाहिए कि जब भी वह बिना कंडोम के यौन संबंध बनाते हैं तो गर्भधारण होने की सम्भावना बनी रहती है।

- इस बारे में भी चर्चा करें कि कई बार लोग या तो गलती से या फिर लापरवाही/सकोंच या अन्य कई कारण जैसे सामाजिक मूल्य, एवं मान्याताओं के कारण गर्भधारण से संबंधित निर्णयों में अपने पत्नि/साथी के साथ भागीदार नहीं होते।

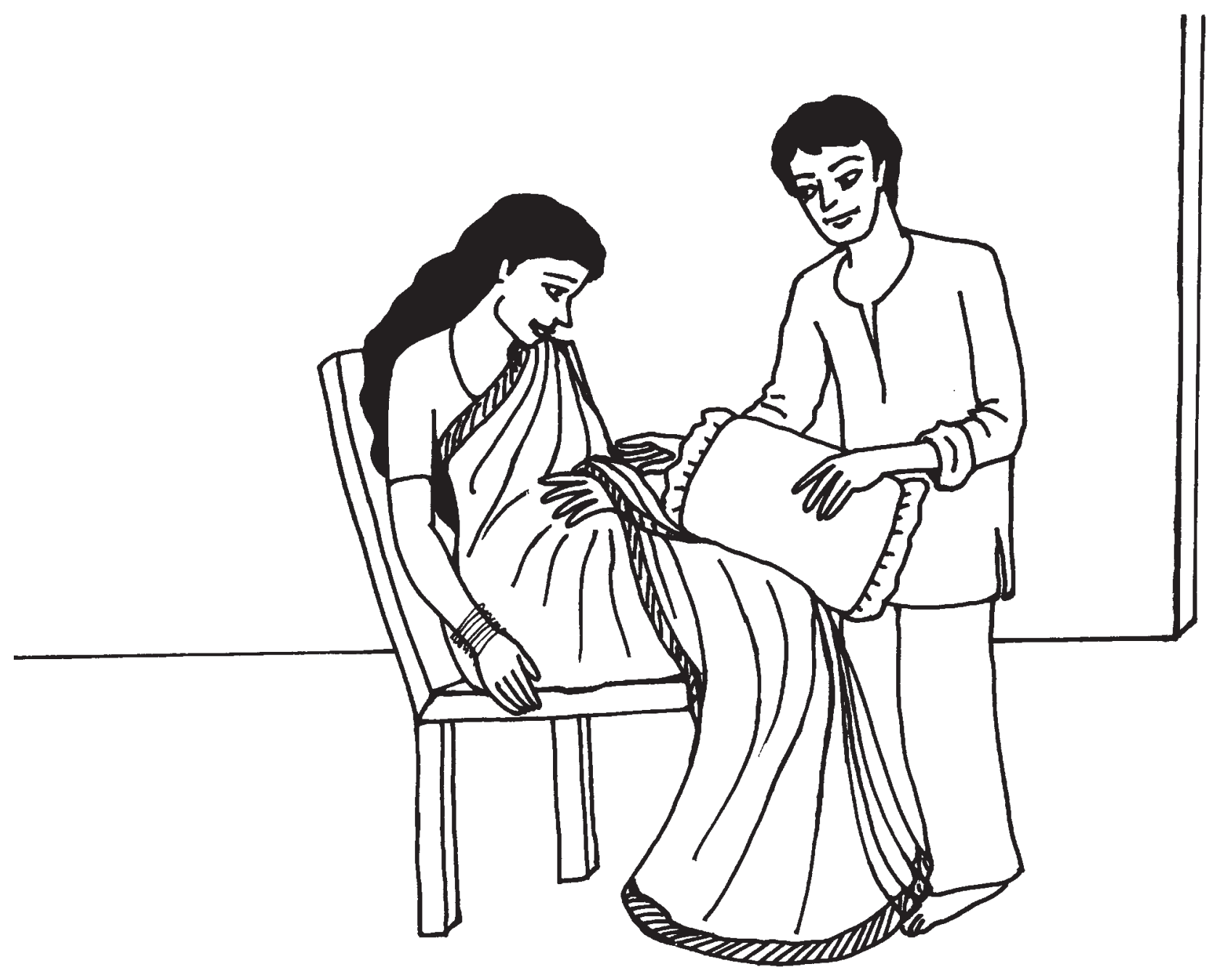




\section{रघु और पिंकी की कहानी}

भाग 1

रघु और पिंकी की शादी अभी पिछले दिनों ही हुई थी। रघु इस शादी से बहुत खुश था, उसे उसके पसंद की बीबी मिली। शादी की पहली रात को वह काफी रोमांचित और उत्तेजित था...

आपके अनुसार इस स्थिति में क्या होना चाहिये...

- गर्भ निरोधक के बारे में चर्चा करना। क्या यह इस स्थिति में सम्भव है?

- गर्भ निरोधक के सही इस्तेमाल की जिम्मेवारी किसकी है-रघु की या पिंकी की?

- महवारी की अवस्था के बारे में चर्चा करना जब सेक्स करने से पिंकी गर्भवती हो सकती है? क्या इस स्थिति में यह चर्चा करना सम्भव है?

\section{भाग 2}

शादी के दो महीनों के बाद पिंकी ने रघु को आकर बताया कि उस महीने उसे मासिक-धर्म नहीं हुए। पिंकी के अनुसार उसे लग रहा है कि वह गर्भवती हो गयी है, यह सुनकर रघु को उत्सुकता हुई कि उसे लड़का होगा या लड़की। रघु, पिंकी को लेकर स्वास्थ्य केन्द्र जाता है, लिंग जाँच से यह मालूम हुआ कि उनका होने वाला बच्चा एक लड़की है...

अब समूह से पूछिये

- आपके अनुसार रघु और पिंकी को क्या यह जाँच करानी चाहिये थी? अगर हाँ तो क्यों? अगर नहीं तों क्यों?

- लिंग जाँच के सामाजिक, पारिवारिक और व्यक्तिगत परिणाम क्या होंगे?

\section{भाग 3}

रघु और पिंकी ने इस गर्भ को रखने का निर्णय लिया। दोनों ही अपने आने वाली बच्ची को लेकर काफी उत्सुक थे...

अब समूह से पूछिये

- आप पिंकी और रघु के निर्णय के बारे में क्या सोचते हैं?

- अब जबकी पिंकी गर्भवती है, रघु का पिंकी के प्रति क्या ज़िम्मेदारी होनी चाहिये? पिंकी को स्वास्थ्य केन्द्र ले जाना? घर के काम-काज में पिंकी का सहयोग करना?

- एक दम्पती के लिये लड़कियों और लड़कों की आदर्श संख्या कितनी है? और क्यों? 
उद्देश्य: सेक्स की इच्छा, सेक्स की उत्तेजना एवं संभोग सुख के बारे में चर्चा करना। इस बारे में भी चर्चा करना कि स्त्री पुरुष दोनों में ही सेक्स की आवश्यकता बराबर होती है।

\section{समय- 2 घंटे}

सामग्री- पुराने मासिक पत्र-पत्रिकाएं कैंची, कागज, गोंद, बोर्ड, मार्कर तथा चॉक।

आमतौर पर बहुत सारे युवक यह साबित करने के दबाव में रहते हैं कि, वह सेक्स करने में कितने होशियार हैं? अगर हम उन्हें सेक्स की इच्छा, उत्तेजित होना और संभोग सुख के विषय में जानकारी दें तो उनका डर और परेशानी कम हो सकती है। सक्रिय सेक्स जीवन का मतलब केवल संभोग या जननेद्रियों द्वारा की जाने वाली यौन क्रिया ही नहीं है बल्कि यौन स्पर्श, आपसी/नजदीकी सुख के और भी रास्ते हैं। इन बातों पर चर्चा करते समय युवक हंसी मजाक करेंगें, लेकिन बातचीत या चर्चा ज्यादा से ज्यादा खुल कर हंसी मजाक के माहौल में होते हुए भी विषय की गम्भीरता बनाए रखें। खुद का बचाव करने के लिए युवक चुटकुले/लतीफों का सहारा लेते हैं। ध्यान रहे कि, हमेशा नयी जानकारी लेते समय जो डर दिल में होता है उसे कम करने के लिए इस तरह के चुटकुले/लतीफे एवं हंसी मजाक जैसी बातों का प्रयोग होता है।

विधि

- प्रतिभागियों के चार समूह बनाएं, उन्हें कोई भी नाम दें-ए-बी-सी-डी।

- हर एक समूह को बड़ा कागज, कैंची, गोंद और 2-3 पुराने मासिक पत्र-पत्रिकाएं दें।

- पहले दो समूहों को 'ए' और 'बी' को मासिक में से पुरुषों के कामुक शरीर के अंगो के चित्रों को काटकर उन चित्रों का एक चित्र समूह (कोलाज) बनाने को कहें।

- उसी तरह बाकी दो 'सी' और 'डी' समूह को, स्त्री शरीर के कामुक अंगों को लेकर यह कोलाज बनाने को कहें।
- यह काम करने के लिए उन्हें समय दें।

- चित्र समूह (कोलाज) बनाने के बाद हर समूह को उस कोलाज पर बोलने के लिए कहें।

- चारों समूह से आयी हुई प्रतिक्रियाओं को प्रेरक कहीं पर लिख लें, और चर्चा के दौरान इस नोट का इस्तेमाल करें।

\section{चर्चा के मुद्दे}

- सेक्स की इच्छा का क्या मतलब है?

- पुरुष उत्तेजित हुआ है या नहीं, यह कैसे मालूम होता है? 
- क्या स्त्री एवं पुरुष दोनों को ही ऐसी इच्छा होती है?

- स्त्री और पुरुष अपनी सेक्स की इच्छा को कैसे प्रदर्शित करते हैं?

- पुरुष कैसे और किस वजह से उत्तेजित होता है?

- यह कैसे पता लगेगा कि स्त्री उत्तेजित हुई है या नहीं?

- स्त्री और पुरुष के उत्तेजित होने में क्या फर्क है?
- संभोग सुख का मतलब क्या है?

- परम संभोग सुख (चर्मोत्कर्ष) के दौरान पुरुषों एवं स्त्रियों में क्या होता है?

- सेक्स में, प्यार कितना महत्वपूर्ण है?

- जिससे आप प्यार करते हों, उनके साथ शारीरिक संबंध में क्या भिन्नता होती है? क्यों?

- प्यार के साथ सेक्स संबंध अधिक संतोष देता है? या फिर, बिना प्यार के किये जाने वाला संभोग?

\section{अंत में}

चर्चा को समाप्त करते वक्त निम्नलिखित बातों पर ध्यान दें

- समूह द्वारा बनाए गये चित्र-समूहों की मदद से, यह जोर दें कि, र्त्री एवं पुरुषों के अलग-अलग अंगों में सेक्स की संवेदनशीलता अलग-अलग होती है, तथा कौन सा अंग सेक्स के लिए कितना संवेदनशील है यह उस व्यक्ति विशेष पर निर्भर करता है।

- नीचे दिए गये काम की मदद से यह बताइये कि कामुक शरीर किस प्रकार कार्य करता है?

- सेक्स संबंधों में प्यार का क्या महत्व होता है?

- सुरक्षित सेक्स संबंधों के लिए हमेशा कंडोम के प्रयोग पर जोर दें।

\section{संसाधन पत्रक: कामुक शरीर}

शरीर के हर एक अंग को स्पर्श करने पर आनंद मिलता है, खुशी होती है पर आमतौर पर कुछ खास अंग शरीर के अन्य अंगों से ज्यादा संवेदनशील होते हैं। इन भागों या अंगों को उत्तेजना-केन्द्र कहते हैं। जैसे कि छाती, योनि, भग्नाशय, योनिमार्ग, लिंग, मुंह, कान, गर्दन इत्यादि। आमतौर पर हर एक इंसान में यह अलग-अलग हो सकते हैं। इसलिए आपस में बातचीत करने से या प्रत्यक्ष तौर पर अनुभव लेने पर अपने साथी को किन बातों से या किन अंगों से ज्यादा उत्तेजना मिलती है, यह पता चलता है। आमतौर पर जानवरों में सेक्स की उत्तेजना के समय नर-जानवर मादा की गंध से ही उत्तेजित हो जाता है, यह उस समय होता है जब मादा के प्रजनन का समय होता है, लेकिन पुरुष उससे अलग होते हैं, पुरुषों की उत्तेजना सामाजिक और मानसिक घटकों पर भी आधारित होती है, और यह घटक एक दूसरे से संबंधित
हैं एवं एक दूसरे को प्रभावित करते हैं और एक दूसरे पर निर्भर करते हैं। औरत के मामले में कामुकता इस बात पर निर्भर नहीं करती कि वह प्रजनन की अवस्था में है या नहीं।

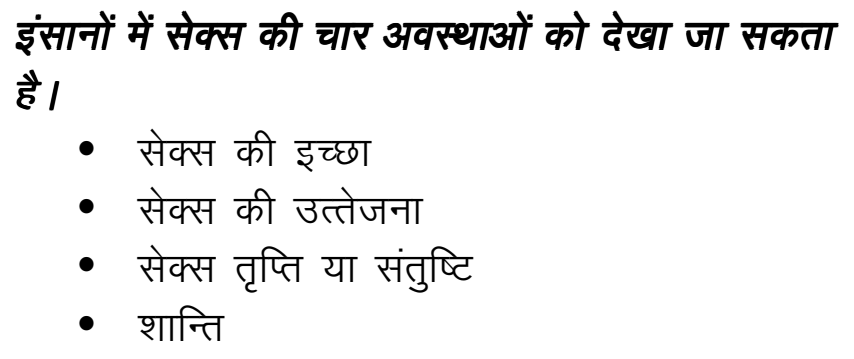

इंसानों में सेक्स की चार अवस्थाओं को देखा जा सकता है ।

- सेक्स की इच्छा

- सेक्स की उत्तेजना

- सेक्स तृप्ति या संतुष्टि

- शान्ति

सेक्स की इच्छा

सेक्स की इच्छा, यानि कि संभोग करना चाहिए, ऐसा लगना। यह इच्छा तब जागृत होती है जब कोई उत्तेजित 
करने वाली सामग्री या चीज दिखायी, सुनाई या महसूस होती है। इन चीजों से इंसानों में चेतनाएं जागृत होती हैं, और इस वजह से यौन संबंध की इच्छा का निर्माण होता है। किसी एक संस्कृति में कोई एक खास बात उत्तेजना देने के लिए कारण बन सकती है। पर वही बात दूसरे समाज में वैसा असर करेगी ऐसा नहीं है। डर, परेशानी, निराशा, खतरे का एहसास एवं ठुकराए जाने का डर व्यक्ति को शान्ति और सुरक्षा का एहसास हो तथा उसका अपने साथी से करीबी और दृढ़ संबंध हों, तो यौन संबंध करने की इच्छा को अच्छी तरह अभिव्यक्त करने में आसानी होती है।

सेक्स की उत्तेजना

सेक्स की उत्तेजना बिना किसी प्रत्यक्ष कारण के भी हो सकती है। मतलब वह किसी इंसान की इच्छा के बिना भी हो सकती है। ऐसा कोई पुरुष है क्या जिसे कि गलत समय पर लिंग खड़ा होने से शर्मिन्दगी महसूस नहीं करनी पड़ी हो? सेक्स की उत्तेजना का एहसास पुरुष के लिंग के खड़ा होने या अंडवे ऊपर हो जाने या और भी टाईट होने पर होता है। इसी प्रकार स्त्रियों में योनिमार्ग या क्लिटोरिस के आकार में बड़ा होने पर सेक्स की उत्तेजना का एहसास कराता है। शरीर शास्त्र के अनुसार विशेष अंगों (लिंग, योनि, स्तन) में खून का बहाव ज्यादा होने पर सेक्स की उत्तेजना होती है। यौन-क्रिया से पूरे शरीर में निर्मित स्नायु तंत्र पर पड़ने वाले दबाव से भी उत्तेजना होती है। इस समय श्वसन क्रिया भी जोरों से होती है और दिल की धड़कन तेजी से चलने लगती है। इस समय एक दूसरे को स्पर्श करना, सहलाना ज्यादा महत्वपूर्ण है। यह जानना जरूरी है कि, जहां पुरुष किसी
भी सेक्स संबंधित सामग्री देखने से ही सेक्स की उत्तेजना का एहसास कर लेता है अथवा उसका लिंग उत्तेजित हो जाता है, वहीं स्त्री को उत्तेजित होने में समय लगता है, जिससे कि उसे ज्यादा समय तक चुंबन, सहलाना एवं स्पर्श की आवश्यकता होती है।

तृप्ति या सेक्स संतुष्टि

यह सेक्स उत्तेजना की सर्वोच्च सीढ़ी है और इसकी व्याख्या करना आसान नहीं है इस तृप्ति का एहसास अलग-अलग व्यक्तियों में अलग-अलग होता है। संभोगसुख के समय आमतौर पर सभी व्यक्तियों में यह पाया गया है कि शरीर के सभी अंगों पर ज्यादा दबाव आता है और उसके बाद शरीर एकदम ढीला पड़ता है और इसके साथ ही बहुत ही संतुष्टि मिलती है। हर बार सेक्स से तृप्ति का एहसास एक समान नहीं होता है चूंकि तृप्ति, सेक्स की उत्तेजना पर निर्भर करती है इसलिए एक ही व्यक्ति में अलग-अलग समय पर विभिन्न तीव्रताओं के साथ सेक्स की तृप्ति का अहसास करता है। पुरूषों की तृप्ति या संतुष्टि की प्रक्रिया में वीर्य का स्खलन होता है।

शान्ति की अवस्था

तृप्ति के बाद एवं दोबारा उत्तेजित होने के बीच की अवस्था शांति की अवस्था है। युवा वर्ग में यह अवस्था 20 से 30 मिनट तक हो सकती है, जबकि प्रोढ़ जिनकी उम्र 50 वर्ष के ऊपर है यह अवधि लंबी भी हो सकती है। स्त्रियों को इस अवधि की आवश्यकता नहीं होती, इसलिए स्त्री एक संभोग में कई बार तृप्ति का एहसास कर सकती है। 
अभ्यास 2.7

\section{सेहत, यौनरोग, एचआईवी तथा एड्स}

सारांश : इस अभ्यास की मदद से युवकों को यौन रोगों एवं उनके लक्षणों की जानकारी देने का प्रयास किया गया है तथा इस बात पर जोर दिया गया है कि यदि किसी भी यौन रोग के लक्षण प्रकट होते हैं तो, तुरन्त उनका इलाज करवाना चाहिए।

उद्देश्य : यौन रोगों को पहचानना एवं उनकी रोकथाम एवं बचाव के बारे में जानकारी बढ़ाना।

समय : 2 घंटे

सामग्री : बोर्ड, कागज, मार्कर पेन, गोंद, पुरानी पत्रिकाएं।

\section{प्रक्रिया}

इस बात पर जोर देना आवश्यक है कि यौन रोगों के लक्षण दिखाई देने पर युवकों को सेक्सोलॉजिस्ट को दिखना जरूरी है न कि वह अपने आप उनका इलाज करने लगें।

स्वयं इलाज करने पर भयंकर परिणाम हो सकते हैं। यौन रोग एवं एड्स की बात करते समय नैतिकता की बात करना भी अत्यन्त आवश्यक है। जिसे भी यौन रोग या एचआईवी हो, यह उनकी नैतिक जिम्मेदारी है कि अपने साथी को इस बात की जानकारी दें।

इस विषय पर जानकारी देने के वक्त निम्न बातों का ध्यान रखना आवश्यक है

- एचआईवी कैसे फैलता है इसकी ताजी जानकारी।

- एचआईवी का इतिहास एवं इस बीमारी की पृष्ठभूमि।

- एचआईवी संक्रमित होना और एड्स की बीमारी होना, इसमें क्या फर्क है।

- वर्तमान में सामान्य तौर पर उपलब्ध इलाज की पद्वति।
साथ में ऐसी भावना को बढ़ावा दें, जिससे कि एचआईवी एवं एड्स पीड़ित व्यक्ति के साथ होने वाले भेदभावपूर्ण व्यवहार को कम किया जा सके।

\section{शुरुआत करने की प्रक्रिया}

1. समूह के साथ बातचीत करते समय यह जोर दें कि सभी ने सेक्स संबंधों से होने वाले यौनरोगों के बारे में सुना होगा।

2. समूह से पूछें कि इनके क्या लक्षण होते हैं? उनके द्वारा बताए गये लक्षणो को बोर्ड पर लिखें।

3. उसके बाद समूह से, एचआईवी तथा एड्स के क्या लक्षण हैं? ऐसा पूछकर उन लक्षणों को बोर्ड पर यौन रोगों के लक्षणों के साथ ही लिखें।

4. समूह के साथ इस बात की चर्चा करें कि यौन रोग के लक्षण को पहचानना, लक्षण दिखायी देने पर डाक्टर को दिखाना, डाक्टर द्वारा दी गयी सूचनाओं का ठीक तरह से पालन करना कितना आवश्यक है। 
5. साथ में, गुप्त रोगों से बचाव की भी चर्चा करें, समूह को समझाएं कि एचआईवी के कोई दिखने

\section{वाले लक्षण नहीं होते हैं।}

6. एचआईवी संक्रमण हुआ है या नहीं इसका पता सिर्फ खून की जांच होने के बाद ही चलता है।

7. पूरे समूह को 4-5 छोटे समूहों में विभाजित करें और उनसे कहें कि वह इस सत्र में अपने उन विचारों को रखें कि, यदि उन्हें अन्य लोगों को गुप्त रोगों एवं एचआईवी के बारे में बताना हो तो कैसे बतायेंगे? उनको सलाह दें कि वे समूहों में पोस्टर, टीवी कार्यक्रम, नुक्कड़ नाटक तथा अन्य विधियों के साथ भी प्रयोग की योजना बना सकते हैं। 20 मिनट तक समूह में काम करने के बाद हर एक समूह को उनके किये गये काम को पूरे बड़े समूह में चर्चा करने के लिए कहें।

\section{चर्चा के मुद्दे}

- आपको कौन से यौनरोगों के बारे में मालूम है?
- अपना इलाज खुद करना यह अच्छी बात नहीं है, डाक्टर की सलाह लेनी चाहिए, लोग ऐसा क्यों कहते हैं?

- डाक्टरी मदद लेने के अतिरिक्त यह पता चलने पर कि, यौन रोग हुआ है, एक व्यक्ति को और क्या करना चाहिए?

- इस बारे में आप अपनी प्रेमिका को कैसे बतायेंगे कि, आपको यौन रोग हुआ है और आपने यह रोग उसे भी दे दिया है,यही बात किसी अन्य लड़की को जो कि आपकी प्रेमिका नहीं है, उसे कैसे बतायेंगे?

- एड्स क्या है?

- यौन रोगों के बारे में बात करना इतना कठिन क्यों है?

- एचआईवी से बचने के क्या उपाय हैं?

- एचआईवी पीड़ित व्यक्ति के साथ कैसा व्यवहार करना चाहिए?

- जिसे एड्स हुआ हो, उसके साथ कैसा व्यवहार करना चाहिए?

\section{अंत में}

इस भ्रांति का निवारण करें कि, एचआईवी केवल अनेक व्यक्तियों से यौन संबंध रखने पर होता है या केवल समलैंगिक स्त्री / पुरुष को ही एड्स होता है।

- अपनी ताकत और मर्दानगी दिखाने के लिए ज्यादातर पुरुष अपनी सेहत की देखभाल नहीं करते और सोचते हैं कि, शरीर का ख्याल रखना औरतों की आदत होती है।

- स्त्री-पुरुष यौन संबंध ही एक आम एवं सामाजिक रूप से स्वीकृत यौन संबंध है, ऐसा विचार हमारे सामाजिक मानसपटल पर गहरे रूप से बैठा हुआ है। इसके कारण वे लोग जो समलिंगी नहीं हैं, अपने को एड्स के खतरे से बचा हुआ मानते हैं, ऐसा इसलिए, क्योंकि एड्स के बारे में यह माना जाता है कि यह बीमारी केवल समलैंगी या जिनका यौन व्यवहार सामाजिक रूप से स्वीकृत नहीं है, उन्हीं को होता है। एचआईवी के बारे में समाचार माध्यमों द्वारा हमेशा चर्चा होती है। दस साल से भी ज्यादा समय तक एचआईवी विषाणु के साथ जीने वाले व्यक्तियों के अनुभव दिखाए जाते हैं। इस पर भी एचआईवी पीड़ित व्यक्ति के बारे में अभी भी बहुत से पूर्वाग्रह हैं। इस सच्चाई की ओर ध्यान खींचना चाहिए कि यह पूर्वाग्रह कैसे बने तथा इनको बदलने के लिए आप क्या कर सकते हैं? 
अभ्यास 2.8

\section{क्या मैंने तुम्हें इस बारे में पहले बताया नहीं था}

\section{उद्देश्य :}

- शराब पीने के शारीरिक, भावनात्मक एवं व्यवहारिक परिणाम होते हैं, इस बात को समझाना।

- ऐसी परिस्थितियों की जानकारी देना, जो शराब पीने से उत्पन्न होती हैं तथा एचआईवी से बचाव में बाधा पहुँचाते हैं?

- सभी के साथ मिलकर ऐसे उपायों के बारे में सोचना जिससे कि, वह हमेशा अपना ध्यान रख सकें

समयः 2 घंटे

सामग्रीः बड़े कागज, मार्कर पेन, गोंद अथवा टेप और कार्ड

प्रक्रिया

- युवाओं के मौज-मस्ती करने के कौन से तरीके हो सकते हैं इस बारे में प्रतिभागियों से पूछें। उसमें से तीन घटनायें एक कार्ड पर लिखें। (उनके द्वारा खुद अनुभव की हुई घटनायें और आस-पास के लोगों के निरीक्षण पर आधारित घटनाओं को शामिल किया जा सकता है।)

- अगर समूह से ऐसी जानकारी नहीं आती है तो उनसे ये पूछें कि उन घटनाओं में से किन घटनाओं में शराब का जिक आया है।

- युवा वर्ग शराब क्यों पीता है? इस प्रश्न के उत्तर में आने वाला हर जवाब बड़े कागज / बोर्ड पर लिखें। इसमें कई कारण आ सकते हैं। जैसे: (अ) दूसरों में अपना दबदबा बनाने के लिए। (ब) मजा करने के लिए (स) कौन ज्यादा शराब पी सकता है। (द) दोस्तों के साथ सामंजस्य बैठाने के लिए इत्यादि। इस तरह से कई और जवाब
प्राप्त हो सकता है। ये सभी जवाब पुरुषों से समाज की अपेक्षाओं से संबंधित हैं।

- इसके बाद, शराब पीने के क्या परिणाम होते हैं? ऐसे सवाल पूछने चाहिये। शारीरिक और मानसिक परिणाम तथा मन और व्यवहार पर होने वाले परिणाम। ये सभी जवाब एक बड़े कागज पर लिख लें (सभी लोगों पर एक जैसे परिणाम नहीं होते, परिस्थिति के अनुसार परिणाम बदल भी सकते हैं। कितनी शराब पी है, शराब कितनी तेजी से और कितने समय में पी है, आदमी का वजन और आकार इन सभी बातों पर निर्भर करता है)।

- नीचे दी गयी सारिणी का प्रयोग करके शराब पीने के परिणामों की चर्चा करें।

- अब समूह को दो भागों में विभाजित कीजिये तथा इस बात पर चर्चा करिये कि शराब का किसी व्यक्ति के यौन-जीवन पर क्या प्रभाव पड़ता है तथा इससे जबरन असुरक्षित 


\section{शराब पीने के परिणाम}

\begin{tabular}{|c|c|c|c|}
\hline शारीरिक & मानसिक & व्यावहारिक & भावनात्मक \\
\hline $\begin{array}{l}\text { जी मिचलाना / उलटी आना, } \\
\text { फिसलना / संतुलन खोना, } \\
\text { पैर सुन्न हो जाना, खुद } \\
\text { पर नियंत्रण कम होना, } \\
\text { किसी भी बात पर परेशान } \\
\text { होना, भूलना या विस्मरण, } \\
\text { सपने आना, किसी भी बात } \\
\text { को लेकर उसी के पीछे पड़े } \\
\text { रहना / अड जाना }\end{array}$ & $\begin{array}{l}\text { मन की एकाग्रता } \\
\text { में कमी, परेशानी, } \\
\text { सोच / विचारों में } \\
\text { गड़बड़ी, भुलक्कड़पन, } \\
\text { पढ़ा हुआ भूलने की } \\
\text { आदत, शराब के नशे में } \\
\text { किये गये कार्यों को } \\
\text { भूल जाना }\end{array}$ & $\begin{array}{l}\text { हिंसा तथा निराशापूर्ण } \\
\text { विचार मन में आते हैं, } \\
\text { लज्जा / शर्म नहीं लगती, } \\
\text { रोना आता है, बकवास } \\
\text { करना, गिरते-पड़ते } \\
\text { चलना }\end{array}$ & $\begin{array}{l}\text { कुछ समय के लिये अच्छा } \\
\text { लगता है, अशांति महसूस } \\
\text { करना, अत्याधिक खुशियाँ } \\
\text { अधिकतम दुःख महसूस } \\
\text { करना, गुस्सा आना, या } \\
\text { घिन आना, सर्वशक्तिमान } \\
\text { होने की भावना पैदा होना } \\
\text { अपराजित लगना }\end{array}$ \\
\hline
\end{tabular}

यौन-सम्बन्ध बनाने की प्रवृत्ति पर क्या प्रभाव पड़ता है।

- इस बात पर चर्चा करें कि, निरोध के इस्तेमाल की जानकारी होते हुये भी, यदि कोई व्यक्ति शराब के नशे में असुरक्षित यौन-सम्बन्ध बनाता है तो, इसके क्या परिणाम हो सकते हैं।

\section{चर्चा के सवाल}

समूह से निम्नलिखित प्रश्नों के उत्तर जानने का प्रयास करें:-

- चर्चा में किस विषय ने सबसे ज्यादा आपका ध्यान आकर्षित किया?
- क्या आपको लगता है कि बताई गयी घटनाओं का वास्तविक जीवनचर्या से किसी भी प्रकार का सम्बन्ध है?

- अगर कोई शराब नहीं पीना चाहता तो, अन्य युवकों की क्या प्रतिक्रिया होती है?

- अपना ख्याल रखने और दूसरों को समर्थन देने के लिये हम क्या कर सकते हैं?

- क्या हम कुछ ऐसे दूसरे रास्ते चुन सकते हैं जिनके द्वारा बिना शराब पीये हुये ही मौज-मस्ती करने की संभावना बनी रहती है। 


\section{अन्त में}

- अधिकांशतः शराब पीने वाले असुरक्षित शारीरिक संबंध, बलात्कार, यौनरोग और एचआईवी तथा एड्स से ग्रसित होते हैं। शराब के नशे में कंडोम का इस्तेमाल करने का निर्णय लेना कठिन होता है।

- कुछ पुरुषों को शराब पीने के बाद, दूसरों के प्रति प्यार और दोस्ती की भावना व्यक्त करने में ज्यादा आसानी होती है। किन्तु शराब न पीकर भी खुद की भावना व्यक्त करना एक महत्वपूर्ण बात है।

- यदि युवाओं को शराब की लत से पड़ने वाले दुश्रभावों के बारे में बता दिया जाये तो युवाओं को इससे बचाया जा सकता है।

- युवाओं को ऐसे कार्यक्रम में भाग लेना चाहिए जिसमें कि, शराब पीना ही मुख्य बात नहीं हो तथा मौज-मस्ती के और दूसरे रास्ते भी हों - जैसे कि - कैरम/ताश/शतरंज खेलना। जो नहीं पीते उन पर जोर जबरदस्ती नहीं करनी चाहिये।

- लंबे समय तक चलने वाली शराब की लत, दूसरों पर आर्थिक-सामाजिक निर्भरता को बढ़ावा देती है। जिससे उस व्यक्ति का जीवन बहुत सारी तकलीफों से घिर जाता है।

हमने इस सत्र में ये देखा है कि शराब पीने के मुख्यतः क्या परिणाम होते हैं? युवा वर्ग में शराब के अलावा और भी नशीले पदार्थों के सेवन की लत दिखाई दे सकती हैं, जैसे :- नसवार, गुटखा, बीड़ी-सिगरेट, स्मैक, इत्यादि।

आपके कस्बे/गाँव/बस्ती में, जिसे भी लोगों में नशे की आदत दिखाई देती है तो स्थानीय सम्मानित व्यक्तियों को साथ लेकर नशा-मुक्ति के लिये मार्गदर्शक कार्यक्रमों का आयोजन कर सकते हैं। 



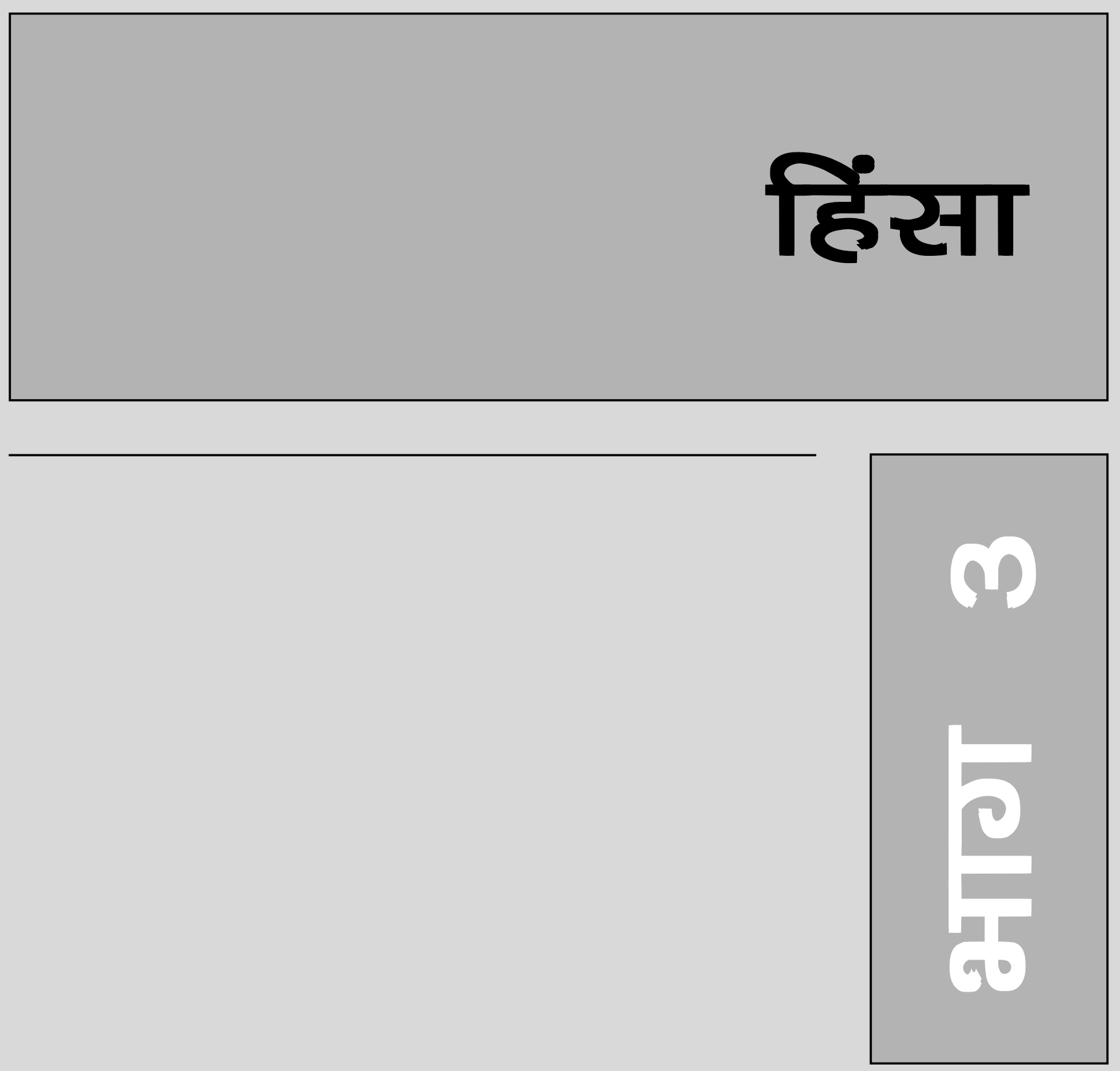



सारांशः इस अभ्यास में बहुत सी ऐसी परिस्थितियां प्रस्तुत की गयी हैं, जिनमें यौन हिंसा का विवरण है। इस अभ्यास में युवाओं को यह निर्धारित करना है कि, किस परिस्थिति में हिंसा है और किसमें नहीं।

उद्देश्य: यौन अत्याचार या हिंसा क्या है? किन परिस्थितियों में यौन अत्याचार को बढ़ावा मिलता है? और, इन परिस्थितियों से कैसे बचा जा सकता है? जैसे विचारों पर चर्चा करना।

समय: 2 घंटे

सामग्री: फ्लिप-चार्ट, पेन, टेप।

\section{प्रेरक के लिए निर्देंश :}

- यह कार्याभ्यास करने से पहले, यदि उस क्षेत्र में यौन अत्याचार के आंकड़ों पर नजर डाल ली जाए तो यह उपयुक्त होगा जैसे कि अत्याचारों के प्रसार, उनसे सम्बन्धित कानूनी जानकारी, साथ में ही यौन अत्याचार से पीड़ित व्यक्तियों की मदद करने वाली संस्थाओं/व्यक्तियों की जानकारी।

- समूह के सवालों का जवाब देते समय उपरोक्त जानकारी देना फायदेमंद साबित हो सकता है। वैसे ही कार्याभ्यास की शुरुआत के पूर्व उन सभी उदाहरणों को देख लेना उचित होगा जो कि स्थानीय परिस्थिति के अनुसार योग्य उदाहरण हैं।

- यौन अत्याचार के मुद्दों की चर्चा करते समय कुछ स्थानों पर विरोध भी हो सकता है, और अन्य स्थानों पर हो सकता है कि पहले से ही यौन अत्याचार के विरोध में मुहिम चल रही हो।

- अक्सर अत्याचारों की चर्चा करना कई लोगों के लिए असुविधाजनक हो सकता है, क्योंकि हो सकता है कि उनमें से कई स्वयं यौन उत्पीड़न के शिकार बन चुके हों और उन्हें मदद की जरूरत हो।

- ऐसा भी हो सकता है कि बहुत से छोटे लड़कों ने स्वयं यौन अत्याचार का अनुभव किया हो, लेकिन शर्म की वजह से उन्होंने किसी को इस बारे में बताया ही न हो। शायद यह सोचकर कि, पुरुष कभी भी यौन उत्पीड़न/हिंसा का शिकार हो ही नहीं सकता है।

\section{प्रक्रिया}

1. यह कार्याभ्यास शुरू करने से पहले, हिंसा या अत्याचार, ये शब्द कहने से हमारे दिमाग में क्या आता है? या हमारी आँखों के सामने क्या आता है? इसकी चर्चा समूह के साथ करें जो भी शब्द
चर्चा द्वारा निकल कर सामने आयें, उन्हें बोर्ड पर लिखें,

2. नीचे दिये हुये वाक्यों को कागज पर पहले से ही लिख लें और तीन अलग-अलग दीवारों पर चिपका दें।

- यह यौन अत्याचार है? 
- यह यौन अत्याचार नहीं है?

- मुझे मालूम नहीं।

3. समूह को यह बतायें कि आप कोई घटना / कहानी पढ़ने वाले हैं। तथा उनकी राय/मत पूछने वाले हैं कि इस घटना/कहानी में यौन हिंसा / उत्पीड़न / अत्याचार है या नहीं। प्रतिभागी अपने विचार, चिपकाये गये तीनों पोस्टरों के आधार पर दे सकते हैं। उन्हें अपनी राय वाले इन तीनों पोस्टरों में से किसी एक पोस्टर के पास जाकर खड़ा होना है।

4. उन्हें यह भी बताना है कि उन्होंने ऐसा निर्णय क्यों लिया?

5. क्या इस कहानी के आधार पर हम हिंसा या अत्याचार की व्याख्या कर सकते हैं? कहानी के आधार पर समूह को हिंसा की व्याख्या करनी है। बोर्ड पर या कागज पर लिखकर, जहाँ भी सभी इसको देख सकें, वहाँ पर इन विचारों को लिखें तथा इन विचारों पर चर्चा करें, और फिर से इस कहानी पर गौर करें।

6. कार्याभ्यास की शुरुआत करने से पहले, यह कार्याभ्यास समूह के साथ करने का सबसे अच्छा और आसान तरीका खोजें। बेशक! आप नये तरीके शामिल कर सकते हैं या खोज सकते हैं।

7. प्रत्येक समूह को एक कहानी पढ़ने और उस पर चर्चा करने के लिए 5 से 10 मिनट का वक्त दें।

8. जो कहानी/घटनायें आपने कार्याभ्यास के लिये चुनी हैं, उसे पढ़ने और चर्चा के बाद तीन राय/निर्णय/मत के आधार पर बने समूह में इसकी चर्चा करें।

9. नीचे दिये गये प्रश्नों पर चर्चा करें।

\section{चर्चा के सवाल}

- क्या ये सब घटनायें/कहानियाँ सच्ची हैं?

- यौन अत्याचार क्या है?

- क्या यह यौन अत्याचार है?

- क्या सभी यौन अत्याचार अपराध हैं?

- लैंगिक अत्याचार रोकने के लिये हम क्या कर सकते हैं?

- लैंगिक अत्याचार का शिकार अधिकांशतः कौन होता है? पुरुष या महिलायें? और क्यों?

- क्या पुरुष भी यौन अत्याचार के शिकार होते हैं?

- लैंगिक अत्याचार होने के बाद उसके परिणाम क्या होते हैं? आप क्या सोचते हैं?

\section{सामाजिक लिंग से जुड़ी हुई मानसिकता :}

- सामाजिक लिंग के प्रति प्रतिभागियों के साथ जो भी विचार-विमर्श हुये उन पर गौर करना चाहिये।

- सामाजिक लिंग के प्रति या अत्याचार के प्रति जो विचार हैं, उसकी जड़ समाज में अंदर तक समायी हुयी है।

- कुछ ऐसी बातें होती हैं, जो समाज द्वारा मान ली गयीं हैं तथा उन पर सवाल न पूछने की मानसिकता दिखाई देती है।

- लोगों में एक उदाहरण को सभी पर लागू करने की मानसिकता होती है।

- सामाजिक लिंग के बारे में चर्चा करते समय कभी-कभी प्रतिभागी हिंसक भी हो सकते हैं।

- जब खुद से संबंधित कुछ बातें सामने आती हैं तो उसे कहने या उसका सामना करने में डर लगता है।

- पुरुष ही सर्वश्रेष्ठ है यह कहने का प्रयास होता है। 


\section{संसाधन पत्रक}

करीबी रिश्तों में यौन व्यवहार - जैसे कि पिता-बेटी, माँ-बेटा, भाई-बहन आदि।

यौन दुर्यव्यवहार - इस शब्द का अर्थ होता है कि, किसी भी बड़े उम्र के आदमी और बच्चों के बीच शारीरिक संबंध।

बलात्कार (रेप) : शारीरिक बल या डरा-धमका कर यौन संबंध के लिये मजबूर करना। मुख, योनि या गुदाद्वार द्वारा स्थापित किया जाने वाला जबरन यौन संबंध।

यौन शोषणः बच्चों एवं युवाओं का इस्तेमाल वयस्कों की यौन इच्छा के समाधान के लिये करना, जैसे कि बाल वेश्या व्यवसाय और नंगी फिल्में, नंगे चित्र बनाना।

यौन उत्पीड़नः किसी व्यक्ति को लालच देकर यौन संबंध के लिये राजी करना, गंदे शब्दों का प्रयोग करना जो कि सामने वाला व्यक्ति सुनना नहीं चाहता / चाहती।

यौन अत्याचार / हिंसाः मानसिक-भावनात्मक एवं शारीरिक तौर पर अपमान, डराना, धमकाना, प्यार और भावनात्मक सहारे की कमी आदि। पुरुष और महिलाओं पर इसके बुरे परिणाम होते हैं। जैसे कि- आत्मसम्मान में कमी, अविश्वास और भावनात्मक असुरक्षा।

शारीरिक अत्याचार / हिंसाः इस प्रकार के अत्याचार में घूंसे मारना, लात मारना, झगड़ा करना, और ऐसी हरकतें करना जिसकी वजह से जख्म हो सकते हैं, या पुरुष और महिला की सेहत पर बुरा असर पड़ सकता है।

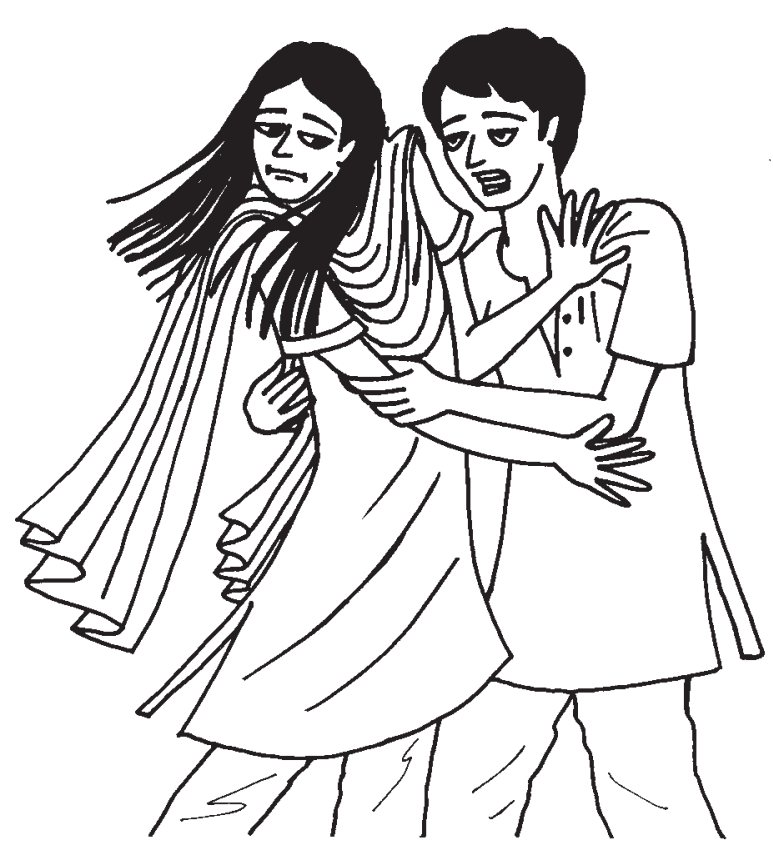




\section{कहानी-एक}

राहुल पड़ोस की लड़की सुनीता को पसंद करता है। कभी-कभी दोनों की आँख-मिचोली हुआ करती है। एक दिन वे दोनों एक सुनसान जगह पर गये और एक दूसरे को चूमना शुरू किया। राहुल ने सुनीता को अपनी सलवार कमीज उतारने के लिये तैयार किया, लेकिन उसके बाद सुनीता मायूस हो गयी और वह वहाँ से जाना चाहती है, राहुल ने उससे कहा कि वह इस सबसे बहुत दूर जा चुके हैं, वे और आगे जा सकते हैं, वह बार-बार सुनीता को सेक्स करने के लिये मनाने की कोशिश करता रहा, साथ में उसने, उससे कहा कि वह बहुत खूबसूरत है और वह खुद उसका बहुत ख्याल रखता है। लेकिन राहुल ने सुनीता से शारीरिक तौर पर जबरदस्ती नहीं की, क्या यह अत्याचार है?

\section{कहानी-दो}

पवन को ट्रेन में लड़कियों को छेड़ना अच्छा लगता था। जब वह लड़कियों को छेड़ता, अगर लड़कियाँ हँसतीं तो वह उनके कूल्हे को छूने की कोशिश करता था। कभी-कभी लड़कियाँ उस वक्त भी हँसतीं थी जब वह उनके कूल्हे को स्पर्श करता था, उसकी वजह से पवन को ऐसा लगता था कि, लड़कियों को यह पसंद है। अगर किसी लड़की को वह छेड़ता है और वह हँसती है, तो क्या यह अत्याचार है?

\section{कहानी-तीन}

विष्णु एक ऐसे समूह का सदस्य था, जो कभी-कभी छोटी-छोटी उम्र के लड़कों के साथ जबरदस्ती सेक्स किया करता था। एक दिन, विष्णु ने एक छोटे लड़के विकास से कहा, अगर वह उसे सेक्स करने देता है तो वह दूसरे लड़कों से उसे बचायेगा। क्या यह अत्याचार है?

\section{कहानी-चार}

राजेश और मीना की शादी के दो साल हो गये थे और आमतौर पर वे दोनों आनंदमयी सेक्स जीवन बिता रहे थे। कभी-कभी राजेश घर देरी से आता, तब तक मीना सो जाती थी। राजेश उसे नींद से उठाता और उसके साथ सेक्स करता। कभी-कभी मीना की इच्छा नहीं होती थी, लेकिन राजेश की जिद के आगे वह तैयार हो जाती थी। क्या यह अत्याचार है? 


\section{यौन सबंधों कें हिंसा और जोर जबरदस्ती}

सारांश : इस अभ्यास द्वारा यौन सम्बन्धों में होने वाली हिंसा एवं जोर.जबरदस्ती तथा उनके यौन रोगों एवं उसके एचआईवी से सम्बन्धों पर चर्चा की जाएगी।

समय : 2 घंटे।

सामग्री : यौन संबंधों में जोर जबरदस्ती और अत्याचार से जुड़ी नितिन की कहानी।

सत्र के विषय में : ठप्पे वाले सत्र की बातें याद करें तो हमें यह साफ दिखता है कि युवक ज्यादातर नकारात्मक ठप्पों का इस्तेमाल करते हैं, हम यह भी देखते हैं कि नकारात्मक ठप्पों वालों पर अत्याचार होता है।

\section{विधि}

सत्र के शूरूआत में समूह से पूछिए -

- अत्याचार का क्या मतलब है?

- अत्याचार कितने प्रकार के हो सकते हैं? इनकी सूची बनाएं।

- उनके क्या परिणाम होते हैं?

- यौन-अत्याचार का क्या मतलब है?
- यौन अत्याचार कैसे होते हैं? कहां होते हैं? और किसके साथ होते हैं?

- क्या यौन अत्याचार बच्चों के साथ भी होते हैं?

- रोजमर्रा की जिंदगी में हम अपने साथी के साथ किस तरह का बर्ताव करते हैं? इसके बारें मे चर्चा करें।

उपरोक्त चर्चा के पश्चात प्रेरक को सभी प्रतिभागियों को निम्न लिखित कहानी पढ़कर सुनानी चाहिए। 


\section{नितिन की कहानी}

रेश्मा संतोष नगर में रहती है, नितिन उसका पड़ोसी है। रेश्मा और नितिन हम उम्र हैं और एक दूसरे को चाहते हैं। रेश्मा को नितिन के साथ बातें करना अच्छा लगता है। वे हमेशा एक दूसरे से बात करने का मौका ढूंढते रहते हैं। कभी-कभी जब एक दूसरे से अनजाने में भी स्पर्श होता था तब दोनों की आंखें चमकती थीं। यह बात अलग है कि वह लोगों की नजरें चुराकर एक दूसरे को स्पर्श कर लेते थे। इन दोनों का यह प्यार उनके सहेलियों/दोस्तों में भी चर्चा का विषय था। नितिन अपने दोस्तो के साथ अपनी और रेश्मा की मुलाकात के बारे में बताता था। नितिन के दोस्त उसे रेश्मा के साथ सेक्स ना करने के कारण उसका हंसी उड़ाते थे। एक दिन नितिन ने रेश्मा को घर से दूर सिनेमा देखने के लिए चलने के लिए कहा, रेश्मा भी घर से बहाना बनाकर नितिन के साथ सिनेमा देखने गई। घर से कुछ दूर चलते ही नितिन ने सिनेमा हाल की बजाय रेश्मा को लेकर एक लॉज में पहुंचा और एक कमरे में ले गया। कमरे का दरवाजा बंद करके उसने रेश्मा को अपनी बांहों में समेटा। सिनेमा कब जायेगें, रेश्मा ने नितिन से पूछा ... रानी यही अपना सिनेमा है, तुम हीरोइन हो और मै हीरो ... इतना कहते हुये नितिन ने रेश्मा को चूमना शुरू कर दिया। रेश्मा भी उसका साथ दे रही थी लेकिन जब वह पलंग की ओर बढ़ा तो उसे नितिन के इरादों पर शक हुआ। उसने नितिन को आगे बढ़ने से मना किया और घर वापस जाने की बात करने लगी। रेश्मा मना कर रही थी और नितिन मान नहीं रहा था। रेश्मा के लाख मना करने पर भी नितिन उसके साथ सेक्स करने के लिये उसे मनाता रहा। दोनों में झगड़ा भी शुरू हुआ। नितिन जबरदस्ती करना नहीं चाहता था फिर भी उसे रेश्मा पर बहुत गुस्सा आ रहा था। अच्छा तो तुम नहीं मानोगी? नितिन ने कहा, ठीक है मैं तुम्हें नहीं मनाऊंगा लेकिन आज से मेरी-तेरी दोस्ती, प्यार-व्यार सब खत्म, तुम्हें मुझ पर विश्वास नहीं है। आज के बाद हम नहीं मिलेगें। रेश्मा ने नितिन की ओर देखा और कहा, ठीक है चलो मैं तुमसे प्यार करती हूं, और दोनों ने सेक्स का अनुभव लिया। नितिन ने कंडोम का प्रयोग भी नहीं किया। नितिन मन ही मन हंसने लगा, वह आज बहुत खुश था। रेश्मा के साथ सेक्स न करने पर उसका मजाक उड़ाने वाले अपने दोस्तों से वह तुरंत मिलना चाहता था।

\section{कहानी पढ़ने के पश्चात सदस्यों के साथ निम्न सवालों पर चर्चा करें ...}

- ये कहानी काल्पनिक है या वास्तविकता से मिलती जुलती है ?

- क्या इस कहानी में आपको कहीं यौन संबंधों से जुड़ी हुई जोर-जबरदस्ती या अत्याचार दिखाई देता है?

- लड़की ने अगर ना कहा तो उसकी ना में भी हां होती है, लड़के ऐसा क्यों सोचते हैं?

- लड़की किन-किन परिस्थितियों में अपने साथी या प्रेमी के साथ इच्छा न होते हुए भी सेक्स के लिए तैयार हो सकती है और क्यों?

- आपको क्या लगता है, नितिन ने यह काम अपने दोस्तों के दबाव में आकर किया होगा ?

- अगर नितिन दोस्तों का कहना न मानता तो उसके दोस्त उससे किस तरह का बर्ताव करते?

- नितिन ने जो बर्ताव किया क्या वह जबरदस्ती है? और क्यों?

- ऐसी घटनाओं से यदि आप सभी गुजर चुके हैं, तो तब आपकी प्रतिक्रिया क्या थी?

- क्या यौन संबंधों में एक दूसरे से चर्चा होनी चाहिए? आपको क्या लगता है?

- क्या कंडोम का इस्तेमाल करने के बारे में एक दूसरे से चर्चा होनी चाहिए?

- क्या लड़की के मना करने पर भी उसे सेक्स करने के लिए राजी करना चाहिए?

- क्या एक दूसरे के भरोसे का अनादर करना सही है? 
अभ्यास 3.3

\section{विविधता एवं अधिकार - में तथा अन्य}

सारांशः यह अभ्यास सामाजिक नाटक की मदद से यह एहसास करवाने का प्रयत्न करता है कि, हम यदि हम न होकर किन्हीं और परिस्थितियों में रहने वाले कोई अन्य व्यक्ति होते तो क्या होता।

उद्देश्यः अलग-अलग परिस्थितियों एवं लैंगिकता वाले लोगों के साथ सहानुभूति पैदा करना। विभिन्न परिस्थितियों एवं लैंगिकता से आए लोगों के बीच हिंसा के क्या कारण हो सकते हैं, इस पर विचार-विमर्श करना।

सामग्रीः फुलस्केप पेपर, रंगीन स्कैच पेन, चिपकने वाली पट्टी।

समय: 2 घंटा

\section{प्रक्रिया}

चूँकि इस अभ्यास के दौरान, प्रतिभागी विभिन्न परिस्थितियों एवं लैंगिकता वाले लोगों का रोल अदा करते हैं, इसमें काफी हंसी-मजाक होता है। इसका ध्यान रहे, किसी का बुरी तरह मजाक न उड़ाया जाये तथा प्रतिभागियों में एक दूसरे के प्रति सम्मान की भावना हो।

1. अभ्यास शुरू करने से पहले नीचे दिए गये वाक्यों में से जो आसान और ठीक लगे, उन्हीं वाक्यों का इस्तेमाल करें। सत्र में आये हर एक युवक के लिए वाक्य चुनें। आप उचित समझें तो नये वाक्य तैयार करें या फिर कुछ वाक्यों का बार-बार इस्तेमाल करें

2. सभी को एक गोल घेरे में आँख बंद करके बिठायें तथा पेपर हाथ में मिलने के बाद युवकों को टीका-टिप्पणी किये बिना पढ़ने को कहें। वाक्य में दी गयी परिस्थिति में अगर वह खुद
होते तो क्या करते? इस पर उन्हें अकेले में सोचने के लिये कहें।

3. प्रत्येक प्रतिभागी से कमीज के सामने की ओर टेप की सहायता से कागज चिपकाने के लिये कहें।

4. अब सभी को खड़े रहकर अहिस्ता-अहिस्ता कक्षा में घूमने को कहें तथा दूसरों की कमीज पर लिखे हुये वाक्य मन ही मन पढ़ते-पढ़ते घूमने को कहें। एक दूसरे का अभिवादन तो करें, पर बात न करें।

5. फिर से गोल-घेरा बनायें और एक दूसरे की तरफ देखने को कहें, अब हर एक को एक रोल अदा करना है- जो वाक्य उन्हें मिला है, उस वाक्य पर एक कहानी बनाने के लिये कहें। इस कहानी में उनके रोल की परिस्थिति या वस्तुस्थिति का वर्णन होना चाहिये। कहानी बनाने के लिए 5 मिनट का समय प्रदान करें। 


\section{वाक्य}

\begin{tabular}{|l|l|}
\hline मैं एचआईवी संक्रमित हूँ & मैंने एक बार आत्महत्या करने का प्रयास किया था। \\
\hline मैं सड़क छाप हूँ & मेरे पिताजी जेल में हैं \\
\hline मैनें एक बार अपनी प्रेमिका को मारा था & मुझे चरस की लत है \\
\hline मैं लखपति हूँ & मैं र्त्री एवं पुरूष दोनों से सेक्स करता हूँ \\
\hline मेरी माँ वेश्या है & मैं बहरा हूँ \\
\hline मेरा हाथ ऐक्सिडेंट में कट गया था & मैं केवल स्त्रियों से सेक्स करता हूँ \\
\hline मुझे पढ़ना नही आता & मैं गुण्डा हूँ \\
\hline मैं जुआरी हूँ & मैं औरतों की तरह व्यवहार करता हूँ \\
\hline मैं एक पिता हूँ और मैं अपने बच्चे का ध्यान रखता हूँ & मैं मजदूर हूँ \\
\hline मैं शराबी हूँ & मैं यौन कर्मी हूँ \\
\hline मैं समलैंगिक हूँ & मैं लोगों की बात इधर-उधर फैलाता हूँ \\
\hline मुझे एड्स की बीमारी है & मुझे कोई काम-धाम नहीं है \\
\hline मैं डान्स बार जाता हूँ & मैं हिजड़ा हूँ \\
\hline मेरी प्रेमिका ने मुझे धोखा दिया है & मैं ड्रग्स बेचता हूँ \\
\hline & मैं शराब नहीं पीता \\
\hline
\end{tabular}

6. यह पूछिये कि कौन पहले आयेगा, फिर जहाँ सभी गोल घेरे में बैठे हैं, उसके एक कोने से ले कर दूसरे कोने तक या बीच-बीच में उठाकर हर एक को अपनी कहानी सुनाने का मोका दें।

7. कहानी बताने के बाद फिर से अपनी जगह पर बैठने को कहें। कमीज पर लगा हुआ कागज वैसे ही रखें।

8. अब सभी को अपनी-अपनी भूमिका में रहते हुए, अदा किये गये रोल के अनुसार एक दूसरे के जीवन, परिस्थितियों, समस्याओं एवं वस्तुस्थिति के बारे में चर्चा करने के लिये कहें।

\section{चर्चा के मुद्दे}

- कागज पर दी गयी किसी परिस्थिति में रहने वाले, किसी युवक के बारे में आपको पता है?
- इस सीन में रोल करते वक्त आपको कैसा लगा?

- बहुत सी जगहों पर अलग दिखाने वाले युवकों को हिंसा और भेदभाव का सामना करना पड़ता है। उदाहरण के तौर पर गुण्डा, यौनकर्मी का लड़का, शराबी, इत्यादि।

- ऐसा क्यों होता है कि, जब कोई दूसरों से अलग होता है, तो इससे हिंसा को बढ़ावा मिलता है?

\section{अन्त में}

चर्चा करें कि समाज में और कैसे-कैसे लोग हैं, जो औरों से अलग होते हैं।

उनका उदाहरण लें तथा उनके बारे में विचार करें। 


\section{अन्तरंग सम्बन्धों में हिंसा से सम्मान तक}

उद्देश्यः आपसी करीबी रिश्तों में हम, अत्याचार, हिंसा का प्रयोग कैसे करते हैं। इस पर चर्चा करना और उसका विशलेषण करना तथा यह तय करना कि आदर भरे करीबी रिश्ते कौन से होते हैं?

सामग्री: फ्लिप-चार्ट, पेन, चिपकने वाली टेप

समयः 2 घंटे

\section{प्रेरक के लिए निर्देंश}

- इस कार्याभ्यास में स्त्रियों की भूमिका अदा कर नाटक करना है।

- आप अगर केवल पुरुषों के साथ काम कर रहे हैं, तो हो सकता है कि कुछ लोग स्त्री की भूमिका करना पसंद न करें। इसलिये समूह को इसे सहजता से लेने के लिए प्रोत्साहित करें।

- यह देखिये की अगर स्त्री की भूमिका करने के लिये कोई भी तैयार नहीं होता है तो फ्लिप चार्ट का प्रयोग करें। इसके द्वारा उन्हें दृश्यों का वर्णन करने के लिये कहें।

- अक्सर एक बात सामने आती है कि, अन्य पुरुषों द्वारा की जा रही हिंसा रोकने के लिए लोग हिचकिचाते हैं। पति-पत्नी के झगड़े के बीच और कोई दूसरा आदमी कुछ बोले तो उसका संबंध पीड़ित स्त्री से जोड़ा जाता है। जिससे उस स्त्री को पहले से ज्यादा मानसिक और शारीरिक अत्याचार से गुजरना पड़ता है।

- पारिवारिक हिंसा पर चुप्पी साधने की आदत और हमें महसूस होने वाली असहजता की भावना को बदलना होगा और इसके लिए युवाओं को प्रेरित करना ही होगा।

- एक बात और भी ध्यान देने वाली है, अक्सर युवक इस बारे में कम ही सोचते हैं कि प्रेम सम्बन्धों में आदर का क्या स्थान होना चाहिये इसकी वजह से रोजमर्रा की जिन्दगी में प्रेम सम्बन्धों में भी लड़ाई-झगड़े एवं तनाव बना रहता है।

\section{प्रक्रिया}

1. समूह को बतायें कि करीबी रिश्तों में हम कभी-कभी तरह-तरह की हिंसा का प्रयोग करते हैं। इस पर चर्चा करना और उसका विश्लेषण करना ही इस अभ्यास का मुख्य उद्देश्य है।
2. कुल प्रतिभागी कितने हैं, इसके अनुसार चार या उससे कम समूह तैयार करें। हर एक छोटे समूह में 5 से 6 सदस्य हों, उन्हें एक छोटा नाटक या भूमिका/नाट्य तैयार करने के लिये कहें। 
3. दो समूहों को दो अलग-अलग तरीकों से रिश्तों को दर्शाता हुआ रोल करने को कहें। रोल-प्ले के लिये पति-पत्नी और बॉय-फ्रेंड - विवाहित और अविवाहित जोड़ियों के रिश्ते उपयुक्त रहेगें। नाटक के माध्यम से हम, इन रिश्तों में कैसे बर्ताव होता है यह दिखाने का प्रयास करेंगे।

4. पहले समूह से ऐसा रोल प्ले करने को कहें जिसमें हिंसा के दृश्य हों। यह शारीरिक हिंसा भी हो सकती है परन्तु आवश्यक नहीं है। ज्यादा से ज्यादा यथार्थ पर आधारित रहने के लिये कहें। अपने आस-पास इलाके में घटी हुई या अनुभव की घटनाओं को नाटक के रूप में रूपान्तरित करें।

5. दूसरे समूह को ऐसा रोल प्ले करने को कहें जो करीबी रिश्ते में आदर/सम्मान दर्शाता हो। यह रिश्ते सिर्फ आपसी आदर-भाव पर आधारित रहेंगे। इन रिश्तों में झगड़े या मतभेद होंगे पर उनका हल एक दूसरे के प्रति आदर द्वारा निकाला जाना चाहिये। इन रिश्तों में हिंसा नहीं होनी चाहिये। कहानी और दृश्यों को तैयार करने के लिये 15 से 20 मिनट का समय दें और फिर इसे बड़े समूह के सामने प्रस्तुत करने के लिये कहें।

6. हर समूह को रोल-प्ले प्रस्तुत करने के लिए 5 से 10 मिनट का समय दें। इसके पश्चात् बाकी लोगों को उस पर प्रश्न पूछने के लिये मोका दें।

7. दोनों समूहों की प्रस्तुति के बाद फ्लिप-चार्ट का प्रयोग कर निम्न बातों की सूची तैयार करें। जैसे कि- हिंसा होने वाले रिश्तों में क्या-क्या विशेष बातें हैं। करीबी रिश्तों में हिंसा के अलग-अलग प्रकारों, नियंत्रण, जोर-जबरदस्ती, चिल्लाना और प्रत्यक्ष शारीरिक हिंसा पर विचार करने के लिये समूह को प्रोत्साहित करें। उदाहरण देकर समूहों से पूछें। प्रदर्शित घटनाओं में से आदमी के कौन से स्वभाव में हिंसा का पता चलता है? रिश्तों में किन बातों से हिंसा का एहसास होता है?
8. यह लिस्ट दीवार पर लगायें, उसके बाद करीबी रिश्तों की क्या विशेषताएं होती हैं इसकी एक सूची तैयार करें। प्रतिभागियों से, आदर-भाव आधारित रिश्ते बनाने के लिये जिन बातों की जरूरत होती है, उन पर विचार करने के लिये कहें।

9. निम्नलिखित सवालों के जवाब ढूंढने की कोशिश करने के लिए कहें।

10. इस प्रकार का रोल-प्ले किसी अन्य व्यक्ति के करीबी रिश्तों को लेकर किया जा सकता है।

\section{चर्चा के लिये सवाल}

- नाटक में प्रयोग की गयी घटनायें कितनी वास्तविक थीं?

- आपके दृष्टिकोण से परिवारों में होने वाली हिंसा या रिश्तों में होने वाली हिंसा के क्या कारण हो सकते हैं?

- केवल पुरुष ही स्त्रियों पर शारीरिक हिंसा का प्रयोग करते हैं, या स्त्री भी पुरुषों पर हिंसा का प्रयोग करती हैं?

- इस तरह की हिंसा देखने पर आप क्या करते हैं? या क्या कर सकते हैं?

- कहानी में बताये गये अच्छे रिश्तों की घटनायें कितनी वास्तविक हैं? क्या आप आदर पर आध तरित करीबी रिश्ता बना सकते हैं? क्या ऐसी घटनायें हमारी रोजमर्रा की जिन्दगी में घटती रहती हैं?

- अच्छे करीबी रिश्ते बनाने के लिये हम लोग व्यक्तिगत तौर पर क्या कर सकते हैं?

- स्त्री और पुरुषों के बीच आपसी आदर-भाव पर आधारित रिश्ता कैसे जोड़ा जाये तथा करीबी और अच्छे रिश्ते का क्या मतलब है? 


\section{अन्त में}

इस कार्याभ्यास के द्वारा युवकों को घरेलू हिंसा या पारिवारिक हिंसा की सत्यता पर चर्चा करने के लिये प्रोत्साहन मिलता है। इस कार्याभ्यास में उनके इलाके में घटित घटनाओं का उदाहरण लिया जाता है, उनके संबंध से जुड़ी हुई घर की पारिवारिक हिंसा के संदर्भ में जानकारी पाने के लिये आप प्रतिभागी युवकों को प्रेरित कर सकते हैं। अर्थात! यह समूहों पर निर्भर करता है कि पारिवारिक हिंसा से शिकार हुयी औरतों के साथ काम करने वाले किसी एक को यहाँ पर बुलाया जा सकता है अथवा औरतों पर अत्याचार करने वाले पुरुषों के साथ काम करने वालों को भी बुलाया जा सकता है। भारत में अनेक स्थानों पर इस तरह की मुहिम चल रही हैं। जरूरत है उन मुहिमों से जुड़ने की और इसको राष्ट्रव्यापी बनाने की। उदाहरण के तौर पर "मेसवा" (MASVAW- Men's Action for Stopping Violence Against Women) नामक संस्था उत्तर प्रदेश के कई जिलों में सक्रिय है तथा इसके कार्यकर्ता अनेक तरीकों से स्त्रियों पर होने वाले हिंसा के विरूद्ध पुरूषों को एकजुट करते हैं। 



\section{हिंसा से शान्तिपूर्ण सह-अस्तित्व तक}

उद्देश्य : इस तरह की हिंसा के बारे में जानना जो या तो हम करते हैं या हमारे साथ की जाती है। सामग्री : पतली रस्सी, टेप, ए4 साइज के तीन कागज, पिनें।

समय : डेढ़ घन्टा।

\section{निर्देश :}

- जब भी कभी हम हिंसा के बारे में बात करते हैं तो मुख्यतः हम शारीरिक उत्तेजना के बारे में सोचते हैं। यह आवश्यक है कि शारीरिक हिंसा के अलावा भी दूसरे प्रकार की हिंसा के बारे में चर्चा की जाये।

- यह भी आवश्यक है कि युवाओं को उनके द्वारा हिंसात्मक कार्यों को समझने में सहायता प्रदान की जानी चाहिए, क्योंकि अधिकांशतः हम यह सोचते हैं कि हम कभी हिंसा नहीं करते सिर्फ दूसरे ही ऐसा करते हैं।

- इस अभ्यास के द्वारा हम इस निष्कर्ष पर पहुँचेंगे कि कि युवाओं से उनके खिलाफ की गई हिंसा के बारे में बात करना अधिक आसान है - मसलन हिंसात्मक कार्य जो कि घर के बाहर हुयी हो - उसके बारे में बात करना आसान है।

- उनके साथ उन्हीं के घर में की गई हिंसा के बारे में बात करना या उस पर टिप्पणी देना एक अतिसंवेदनशील मुद्दा है। पारिवारिक हिंसा के बारे में टिप्पणियां संवेदनशील है अतः उन पर ज्यादा कोई दबाव नहीं डाला जाना चाहिए।

- उनके द्वारा की गई हिंसा के बारे में बात करना कठिन है क्योंकि वे हमेशा अपने.अपने को सही साबित करने के लिए दूसरे व्यक्ति पर इसका आरोप मढ़ देंगे।

- इस अभ्यास में दो सत्रों का सार है। यदि आपको ऐसा लगता है कि प्रतिभागी अपने बारे में व्यक्गित जानकारी नहीं देना चाहते हैं तो इस अभ्यास में दिये गये वैकल्पिक अभ्यासों का प्रयोग किया जा सकता है जिनमें कि न्यूनतम व्यक्तिगत जानकारी ही चाहिए। जैसा कि प्रथम माड्यूल में बताया गया है कि हिंसा का शिकार होना भविष्य में हिंसात्मक कार्य करने के साथ जुड़ा हुआ है।

- खुद पर हिंसा के दौरान उनको कितनी पीड़ा पहुँची है इस बारे में सोचने को कह कर उन्हें हिंसात्मक होने से बचाया जा सकता है।

- यदि कोई किशोर या किशोरी इस तरह की शिकायत करता है कि उसके साथ किसी प्रकार की हिंसा या दुव्यर्वहार किया गया है चाहे वह घर के अन्दर किया जाने वाला यौन दुर्व्यवहार हो या उसके साथ किसी प्रकार की मारपीट की गई हो। अगर वह 18 साल से कम आयु का है तो प्रेरक द्वारा इसकी शिकायत सम्बन्धित विभाग में की जानी चाहिए। 
विधि

1. इस बारे में बतायें कि इस अभ्यास का उद्देश्य हमारे साथ या हमारे द्वारा की जाने वाली हिंसा की चर्चा करना है।

2. इस बारे में भी बतायें कि हम चार अलगनियां बनायेंगे तथा प्रत्येक प्रतिभागी को कागज की शीट पर विषय सम्बन्धी कुछ शब्द लिखकर इस अलगनी पर टांगने होंगे।

3. प्रत्येक प्रतिभागी को ए4 साइज के कागज की चार-चार शीटें बाँट दें।

4. प्रत्येक अलगनी पर निम्नलिखित कथन लगा दें-

- मेरे साथ की गई हिंसा

- मेरे द्वारा की गई हिंसा

- हिंसा करते वक्त मुझे कैसा लगा

- हिंसा सहते वक्त मुझे कैसा लगा
5. प्रत्येक प्रतिभागी को इन सभी बातों पर कुछ न कुछ लिखने के लिए कहें। प्रत्येक प्रतिभागी को प्रत्येक अलगनी के लिए कम से कम एक उत्तर तो लिखना ही होगा। उनको इस कार्य के लिए 10 मिनट का समय दें। इस बारे में बतायें कि बहुत ज्यादा लिखने की जरूरत नहीं है सिर्फ कुछ शब्द या कोई वाक्य ही लिखना बहुत है तथा इसके बाद इससे सम्बन्धित अलगनी पर लटका देना चाहिए।

6. एक-एक करके समूह के सभी प्रतिभागियों को अपने-अपने उत्तर पढ़ने के लिए कहें। वे अन्य कोई आवश्यक उदाहरण भी दे सकते हैं तथा दूसरे प्रतिभागी उनसे प्रश्न कर सकते हैं।

7. जब सभी प्रतिभागी अपने-अपने कागजों को अलगनी पर लटका दें तो निम्नलिखित प्रश्नों पर चर्चा की जानी चाहिए।

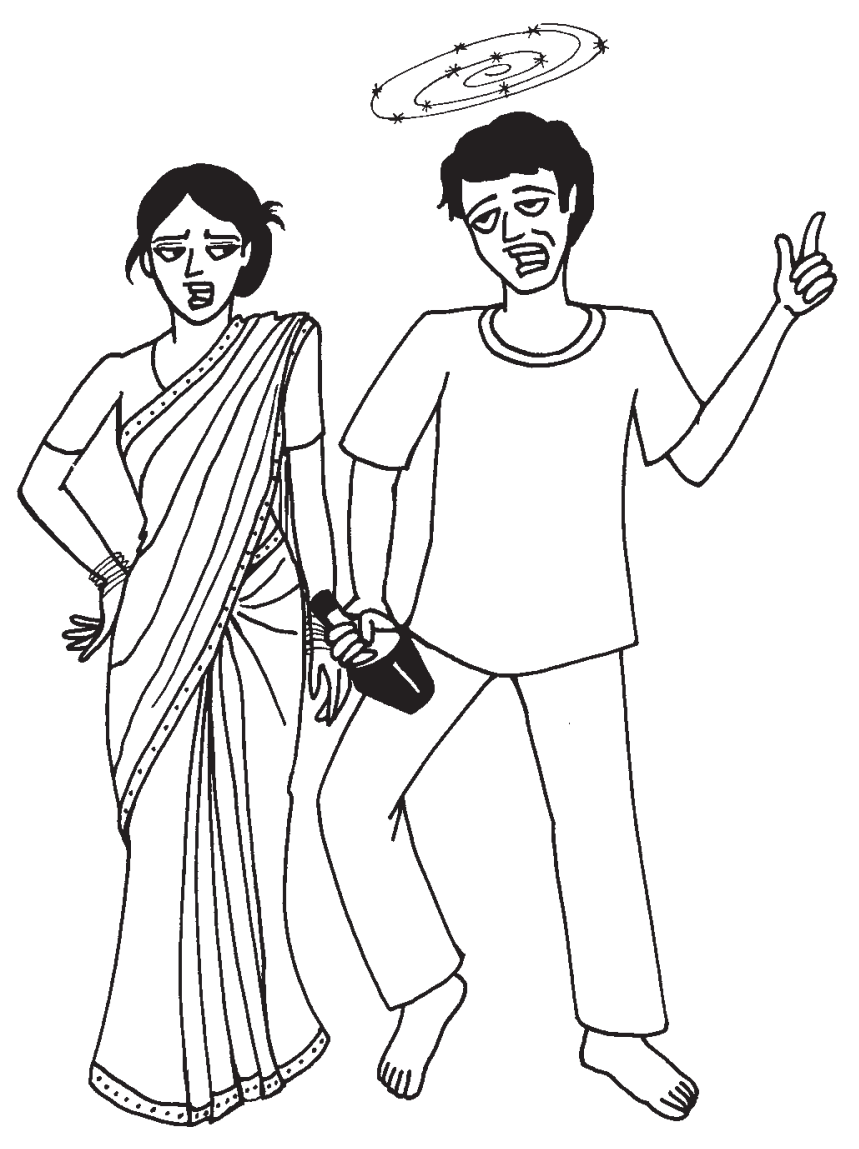




\section{चर्चा के लिए प्रश्न}

- हमारे खिलाफ की जाने वाली सबसे मुख्य हिंसा कौन सी है?

- इस हिंसा का शिकार होने पर हमें कैसा लगता है?

- हमारे द्वारा की जाने वाली हिंसा का सबसे प्रचलित स्वरूप क्या है?

- हमें कैसे पता चलेगा कि हम सच में दूसरे के प्रति हिंसात्मक व्यवहार कर रहे हैं?

- क्या हमारे खिलाफ तथा हमारे द्वारा की जाने वाली हिंसा में कोई सम्बन्ध है?

- हिंसा करते समय हमें कैसा लगता है?

- क्या कोई हिंसा दूसरी तरह की हिंसा से भी भयावह हो सकती है?

- सामान्यतः, जब हम हिंसक होते हैं या हमारे साथ हिंसा की जाती है तो क्या हम इसके बारे में चर्चा करते हैं?
- क्या हम इसकी शिकायत करते हैं? क्या हम इस बारे में बात करते हैं कि हमें कैसा लगा? यदि नहीं तो क्यों नहीं?

- शोध के अनुसार हिंसा एक ऐसा घटना-चक्र है जिसमें कि हिंसा की शिकार व्यक्ति ही भविष्य में हिंसात्मक हो जाता है। यदि यह सही है तो हम इस हिंसात्मक घटना-चक्र को किस प्रकार रोक सकते हैं?

\section{सम्बन्धित जानकारी}

हो सकता है कि कुछ किशोर इस अभ्यास के पश्चात् अपने आस-पास होने वाली हिंसा के बारे में कुछ करना चाहें तो इस उद्देश्य को ध्यान में रखकर इस माड्यूल में बनाये गये अभ्यास 3ण 1 तथा 3ण2 का प्रसंग दिया जा सकता है या फिर उनका प्रयोग किया जा सकता है।

\section{अन्त में}

समूह से पूछें कि उनके द्वारा अनुभव की गयी हिंसा के बारे में चर्चा करना उन्हें कैसा लगा। यदि समूह में से कोई भी प्रतिभागी अपने खिलाफ की गई हिंसात्मक कार्यवाही के प्रति ध्यान आकर्षित करता है तो प्रेरक को चाहिए कि वह ऐसे प्रतिभागी को सम्बन्धित सेवाओं तथा अपने संस्थान के वरिष्ठ सदस्यों के साथ चर्चा करने तथा शिकायत करने के लिए प्रेरित करें। 
अभ्यास 3.6

\section{में क्या करता हूँ जब मुझो गुस्सा आता है ?}

उद्देश्य : प्रायः नाराज़ होने पर हम हिंसा पर उतर आते हैं और कभी-कभी तो नाराज़गी का एहसास होने से पहले ही हम ऐसा रवैया अपना लेते हैं। कुछ लोग चिल्लाकर, सामान फेंककर, दूसरों को मारकर अपना गुस्सा ज़ाहिर करते हैं। जबकि कुछ लोग कभी-कभी मौन रहकर या फिर अर्न्तमुखी होकर भी अपनी नाराज़गी व्यक्त करते हैं।

इस अभ्यास का उद्देश्य युवाओं को अपने गुस्से के बारे में जानने तथा गुस्से में कैसे सकारात्मक तथा अपने आपको नुकसान न पहुँचाने वाला व्यवहार करने के बारे में जानकारी प्रदान करना है।

सामग्री : सचित्र-पुस्तिका, ए4 साइज के कागज, स्केच पेन, टेप, संसाधन पत्रिका की प्रतियां।

समय : 1 घन्टा।

\section{निर्देश :}

सामान्यतः, लड़के या पुरुष सामाजिक तौर पर अपनी भावनाओं को व्यक्त नहीं करना चाहते हैं। जब भी कभी हम दुःखी होते हैं या अवसाद से घिरे होते हैं तो हमें इस बारे में बात न करने के लिए प्रेरित किया जाता है। अधिकांशतः बात न करने के कारण अवसाद या गुस्सा हमारी प्रवृत्ति को हिंसात्मक बना देता है।

यह अभ्यास आगे की प्रक्रिया के लिये सहायक हो सकता है तथा इसका प्रसंग आगे के अभ्यासों में दिया जा सकता है। इस अभ्यास के दौरान समूहों में वाद-विवाद होने की सम्भावना रहती है। इसलिए प्रेरक को याद दिलाते रहना चाहिए कि सिर्फ शब्दों का ही प्रयोग किया जाये।

\section{विधि}

1. विषय की वस्तुर्थिति के बारे में संक्षिप्त परिचय के द्वारा इस अभ्यास की शुरूआत की जानी चाहिए जैसे कि अधिकांश किशोर-किशोरी गुस्से तथा हिंसा के बारे में भ्रमित होते हैं तथा वे सोचते हैं कि दोनों ही बातें समान हैं। इस बात पर जोर दिया जाना चाहिए कि गुस्सा एक सामान्य भावना है जो कि जीवन में कई बार
विकसित हो सकती है। हिंसा, गुस्से को जाहिर करने का एक तरीका है या यह कहा जा सकता है कि यह एक ऐसा व्यवहार है जिसके द्वारा गुस्सा जाहिर किया जा सकता है किन्तु गुस्से को जाहिर करने के दूसरे अन्य तरीके भी हैं जो कि हिंसा की तुलना में कहीं अधिक उत्तम तथा सकारात्मक हैं। यदि हम गुस्से को जाहिर करने के बारे में सीख जायें तो यह अच्छा होगा कि हम इसे अपने अन्दर इकट्ठा करने की बजाए 
इसे व्यक्त कर पाऐं नहीं तो यह किसी भी दिन फूट सकता है।

2. समूह को इस बारे में बताएं कि इस अभ्यास में हम इस बारे में चर्चा करेंगे कि गुस्सा आने की स्थिति में हमें किस प्रकार का व्यवहार करना चाहिए।

3. प्रत्येक प्रतिभागी को एक संसाधन पत्रिका प्रदान करें। प्रत्येक प्रश्न को पढ़ें तथा सभी प्रतिभागियों से इन सभी के उत्तर जानने का प्रयास करें। प्रत्येक प्रश्न के लिए 2 से 3 मिनट का समय प्रदान करें।

4. पर्चे को भरने के पश्चात् समूह को 4 या 5 प्रतिभागियों के छोटे-छोटे समूहों में बाँट दें तथा उन्हें दूसरों के प्रति लिखी गई टिप्पणियों पर चर्चा करने के लिए कुछ समय प्रदान करें। इस समूह कार्य के लिए 20 मिनट का समय दें।

5. प्रतिभागियों के छोटे समूहों को एक-एक सचित्र-पुस्तिका बाँट दें तथा उनसे गुस्से के नकारात्मक तरीकों तथा सकारात्मक तरीकों की सूची बनाने को कहें।

6. समूहों को अपनी सूची के लिये 10 मिनट का समय प्रदान करें, इसके पश्चात् प्रत्येक समूह को अपने उत्तरों से सम्पूर्ण समूह को अवगत कराने को कहें।

7. यह सामान्य बात है कि सकारात्मक व्यवहार की सूची में निम्नलिखित व्यवहारों का समायोजन किया गया हो :

- खुली हवा में साँस लेना या 10 तक गिनना।

- बिना गुस्सा किये सहो हुये शब्दों में अपनी बात कहना।

यह आवश्यक है कि इस बात पर जोर दिया जाये कि, खुली हवा में साँस लेने का अर्थ यह नहीं है कि, कोई अपने वाहन में बैठकर कहीं बाहर चला जाये तथा उसे तेजी से चलाये तथा अपने आपको खतरे में डाल ले या किसी शराब के अड्डे पर बैठकर शराब पीता ही चला जाये। यदि ये दोनों ही व्यवहार सूची में सम्मिलित नहीं किये गये हैं तो संक्षेप में इनके बारे में बतायें :-

खुली हवा में साँस लेना का अर्थ साधारणतः झगड़े वाली जगह को छोड़ देने से होता है जिससे कि जिस व्यक्ति पर गुस्सा आ रहा है उससे दूर हुआ जा सके।
इसके लिये कोई व्यक्ति 10 तक गिनती गिन सकता है, गहरी साँस ले सकता है या फिर टहल सकता है, या कोई ऐसी क्रिया कर सकता है जिससे कि वह शान्ति महसूस कर सके तथा उसका गुस्सा ठण्डा पड़ जाये। सामान्यतः, यह आवश्यक है कि वह व्यक्ति जिसे गुस्सा आ रहा हो वह दूसरे व्यक्ति से कहे कि वह बाहर जा रहा है क्योंकि उसे गुस्सा आ रहा है, जैसे कि : मैं तुमसे परेशान हो चुका हूँ तथा खुली हवा में साँस लेने जा रहा हूँ मैं नहीं चाहता कि मैं गुस्से में चीख्ने-चिल्लाने लगूँ। इसलिये टहलने जाना चाहता हूँ। जब मेरा गुस्सा शान्त हो जायेगा तब हम इस बारे में दोबारा बात करेंगे।

बिना गुस्से के सधे हुये शब्दों में अपनी बात कहने का अर्थ निम्नलिखित दो तरीकों को सीखना है :

- दूसरे व्यक्ति को यह बताना कि आप क्यों परेशान हैं,

- गुस्सा या अपशब्दों का प्रयोग किये बिना सामने वाले व्यक्ति को अपनी अपेक्षाओं के बारे में बताना। उदाहरण के लिये :-

\section{मैं तुमसे नाराज हूँ क्योंकि मैं चाहता हूँ कि तुम :} (समूह को उदाहरण दें जैसे कि)

यदि आपका कोई साथी आपको इंतजार करा कर नियत समय पर देर से पहुँचता है तो शायद आप यह कहें कि - तुम बदतमीज हो, हमेशा ऐसा ही करते हो, मैं यहाँ तुम्हारे इन्तजार में परेशान हो रहा हूँ ... इसकी बजाय आप यह भी कह सकते हैं कि - देखों, मैं तुमसे नाराज हूँ क्योंकि तुम देर से आये हो, मैं चाहता हूँ कि तुम समय से आया करो नहीं तो पहले बता दिया करो कि तुम्हें देर हो जायेगी।

समूह से अन्य प्रस्थितियों के बारे में पूछें जो दैनिक जीवन में घटित होती हैं तथा जिनमें गुस्सा होने की संभावना होती है।

\section{चर्चा के लिये प्रश्न}

- क्या पुरुषों को बिना हिंसा (मारपीट) के अपना गुस्सा जाहिर करने में परेशानी होती है? और क्यों? 
- सामन्यतः हमें पता होता है कि लड़ाई-झगड़े से कैसे बचा जाय, परन्तु हम ऐसा नहीं करते हैं क्यों?

- क्या यह सम्भव है कि, झगड़े/गुस्से से बचने के लिये हमें वह जगह छोड़ देनी चाहिये? क्या आपने कभी भी ऐसा किया है?
- आपका अनुभव कैसा रहा?

- क्या गुस्से में अपशब्दों का प्रयोग करने से बचा जा सकता है?

\section{संसाधन पत्रक: नाराज़गी में क्या करना चाहिए?}

1. हाल में हुई इस घटना पर विचार कीजिए, जब आप नाराज़ हुए थे। क्या हुआ था? संक्षेप में उस घटना के बारे में लिखिए। (एक या दो वाक्यों में)

2. अब, उस घटना के बारे में सोचें और याद करने की कोशिश करें कि उस वक्त आपकी सोच क्या थी और आप कैसा महसूस कर रहे थे, जब आप नाराज़ थे। जो आपके शरीर ने महसूस किया, उनमें से किसी एक या दो बातों को यहाँ लिखें।

3. उस घटना के बारे में विचार कीजिए, जब आप नाराज़ थे, कैसे आपने अपने गुस्से को ज़ाहिर किया था? उस समय आपका व्यवहार कैसा था?

(जब आप नाराज़ थे, तो आपका व्यवहार कैसा था या आपने उस वक्त क्या किया था? अपनी प्रतिक्रिया के बारे में कुछ शब्द लिखिए)

\section{अंत में}

अगर समय की कमी न हो तो इस अभ्यास के समापन का एक दिलचस्प तरीका यह है कि समूह से भूमिका नाटक करने को कहें या उनसे कहें कि वह उन स्थितियों के उदाहरणों पर विचार करें, जिनमें कि, धमकाने व समझाने वाले शब्दों का प्रयोग किया गया हो, जिससे इन शब्दों के बीच के अन्तर को स्पष्ट किया जा सके। 

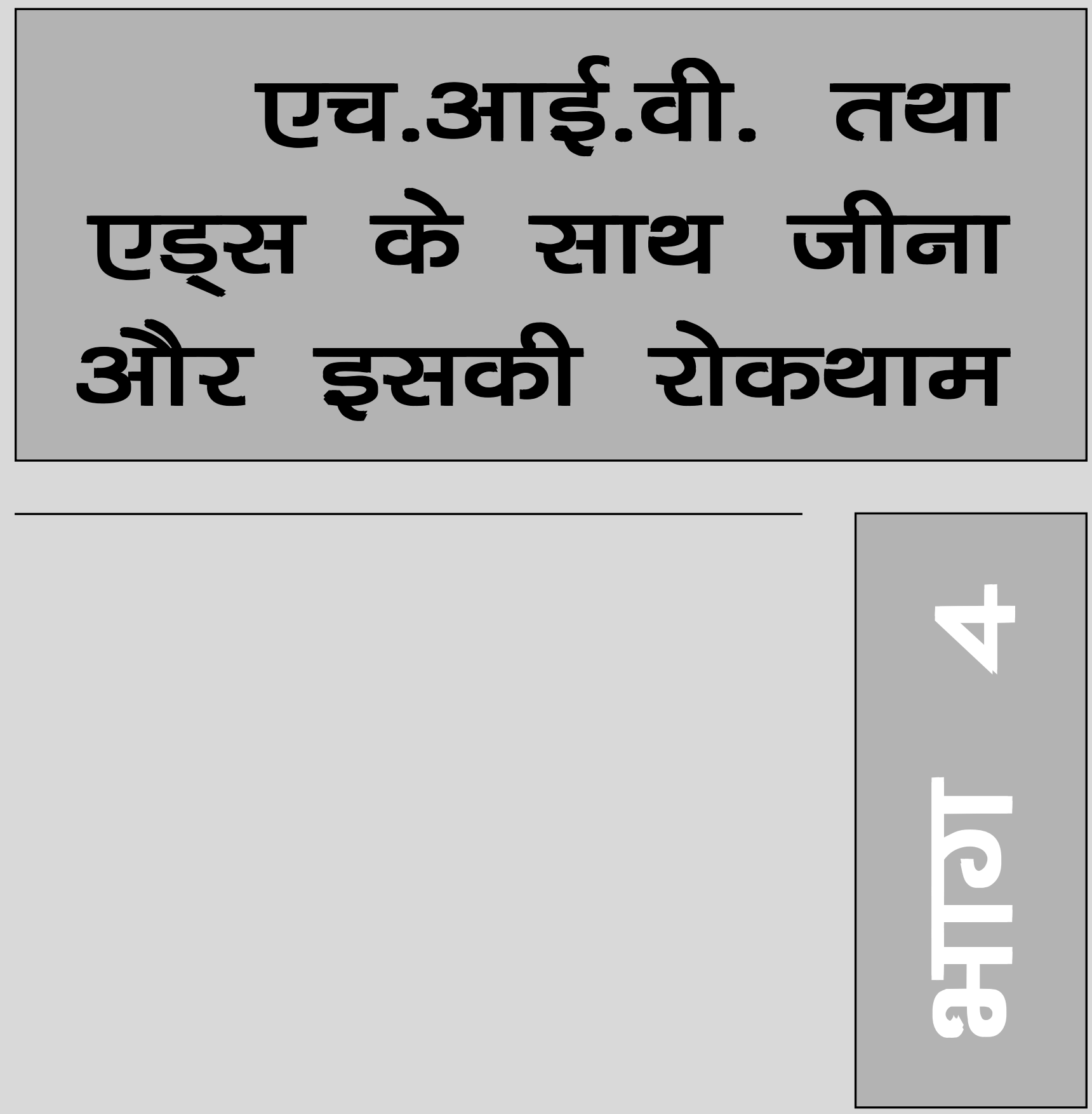



\section{राजू की कहानी}

सारांशः इस अभ्यास की मदद से एड्स के बारे में कई जानकारियां दी जा सकती हैं। साथ ही साथ एड्स से सम्बन्धित धारणाओं एवं पूर्वाग्रहों के बारे में भी बताया जा सकता है।

उद्देश्यः एचआईवी तथा एड्स का क्या मतलब है? वह कैसे फैलता है? उस पर प्रतिबंध कैसे रखें? एवं एड्स की अन्टी-रेट्रोक्हायरल (ARV) दवाईयों के बारे में तथा अन्य इलाज के तरीके के बारे में बताना की उनकी सही जानकारी कहॉ से मिल सकती है साथ में यह चर्चा भी करना कि एचआईवी का परीक्षण कहाँ करवाया जा सकता हे। एचआईवी संक्रमित व्यक्तियों के प्रति दृष्टीकोणों में परिवर्तन लाना।

समयः 2 घंटे

आवश्यक सामग्रीः सभी सदस्यों के लिये "राजू की कहानी" की एक-एक प्रति।

इस कार्याभ्यास के लिए समूह के साथ पहले से ही संबंध होने चाहिये, क्योंकि कार्याभ्यास में एक छोटा सा नाटक करना है, जिसमें, युवकों को स्त्रियों का चरित्र निभाना पड़ेगा। पूर्वाग्रहों और किसी का मजाक उड़ाने के पीछे क्या कारण होता है इस विषय पर चर्चा करने के लिए यह अच्छा मौका है।

\section{प्रक्रिया}

- इस अभ्यास में शामिल होने के लिए तकरीबन 8 प्रतिभागियों की जरूरत है, जो नाटक में अभिनय करने को तैयार हों। अतः यह आवश्यक है कि इसकी तैयारी कुछ पहले से की जाए।

- जो नाटक करने को तैयार हों, उनके सामने राजू की कहानी नाम का छोटा सा नाटक करने का प्रस्ताव रखें। उन्हें यह बताएं कि यह नाटक समूह के अन्य सदस्यों के सामने पेश की जानी है। यह भी बताएं कि, नाटक का प्रभाव कम न हो, इसलिए वे लोग कहानी को गुप्त रखें।

- जिस दिन ये नाटिका पेश की जानी है, उसी दिन उसका ऐलान करें कि आज हम "राजू की
कहानी" नाम की एक नाटक आप के सामने करने वाले हैं, नाटक की कहानी को ध्यान से और बारीकी से गौर करें।

- शुरू में पूरा नाटक पेश करें.........ताकि नाटक का विषय ठीक प्रकार से समझ में आ सके। फिर नाटक को चार हिस्सों में विभाजित करें, जैसे पहला हिस्सा सूत्रधार के पहले संवाद से लेकर स्वास्थ्यकर्मी के पहले संवाद तक। दूसरा हिस्सा सूत्रधार के दूसरे संवाद से लेकर राजू और संजू के होटल के सभी संवादों तक तथा तीसरा हिस्सा सूत्रधार के तीसरे संवाद से लेकर राजू और उसके सभी दोस्तों के बीच के सभी संवादों तक। और पिंकी के अंत के संवादों वाला चौथा हिस्सा। 
- नाटक के हर हिस्से को करने के बाद रुक जायें, अगर किसी को ऐसा लगे कि पेश किये गये हिस्से में बताई गई जानकारी ठीक नहीं है, तो उसे उस जगह पर खुद भूमिका करने के लिए कहें या चर्चा द्वारा समुचित जानकारी देने का प्रयास करें। फिर अगले हिस्से को पेश करें और फिर रुक जायें। चर्चा करें और समुचित जानकारी देने का प्रयास करें। नाटक तब तक चालू रखें जब तक कि सभी प्रतिभागियों द्वारा उठाये गये सवालों का ठीक-ठीक उत्तर न दे दिया जाये।

\section{चर्चा के मुद्दे}

- पहली बार जब नाटक पेश किया गया तब आपको कैसा लगा?

- जो भी बदलाव किये गए हैं, उनके बारे में आपकी क्या राय है?

- एचआईवी और एड्स का क्या मतलब है?

- किसी व्यक्ति पर एड्स वायरस का हमला कैसे होता है?
- एचआईवी से खुद का बचाव कैसे किया जा सकता है?

- क्या युवक एचआईवी की जाँच कराते हैं? क्यों कराते हैं? और क्यों नहीं कराते हैं?

- एचआईवी जाँच के लिये जाने वाले व्यक्ति से किस तरह का बर्ताव किया जाता है?

- आपको क्या लगता है, एचआईवी जाँच के लिये जाने वाले व्यक्ति सें किस ढंग का बर्ताव किया जाना चाहिये?

- किसी को एड्स की बीमारी हुई है, अगर ऐसा मालुम हो तो स्वास्थ्य केन्द्र में क्या होता है?

- एचआईवी जाँच की रिपोर्ट आने की राह देखते वक्त लोगों के दिल में कौन से विचार /कल्पना मंडराते हैं?

- आपके आस-पास एचआईवी की जाँच या फिर परीक्षण कहाँ पर किया जाता है? क्या इसके बारे में आपको पता है?

- एचआईवी पॉजिटिव/संक्रमित व्यक्ति के इलाज के लिए कौन सी दवाईयाँ उपलब्ध हैं?

- एचआईवी पॉजिटिव/संक्रमित स्त्री या पुरुष के प्रति अन्य लोगों के क्या विचार होते हैं।

\section{अन्त में}

नीचे दी गयी बातों का ज्ञान होना जरूरी है:-

- एचआईवी वायरस का हमला कैसे होता है? इस बीमारी की ऐतिहासिक पृष्ठभूमि कैसी है? एचआईवी संक्रमित व्यक्ति और एड्स के बीमार व्यक्ति, इन दोनों में क्या फर्क है? क्या इसका इलाज मौजूद है?

- एक मुख्य बात जिस पर जोर देना है, वह यह है कि, एचआईवी संक्रमित व्यक्तियों के साथ सामाजिक दुर्व्यहार नहीं करना चाहिए। इसके लिए यह आवश्यक है कि, समूह के सदस्य इन पूर्वाग्रहों के बारे में विस्तार से चर्चा करें तथा इससे निपटने के लिये क्या-क्या किया जा सकता है, इन पर भी चर्चा करें।

- यह बात बताने का प्रयत्न करें कि एचआईवी केवल उनको ही नहीं होता जो सामाजिक रूप से बिगड़े हैं या जिनका व्यवहार समाज में स्वीकृत नहीं है। एचआईवी किसी को भी हो सकता है और कोई भी इससे बच सकता है। 


\section{राजू की कहानी}

सूत्रधार : राजू की उम्र 18 साल है और वह रात्रि स्कूल में पढ़ता है और दिन में एक एकाउन्टिंग फर्म में काम करता है। एक दिन उसके दोस्त को दुर्घटना में चोट लग जाती है जिससे उसको खून की जरूरत पड़ती है, राजू अस्पताल में जाकर रक्तदान करता है ताकि उसके दोस्त को खून मिल सके कुछ दिन बाद राजू को अस्पताल में काम करने वाले स्वास्थ्यकर्मी का बुलावा आता है।

स्वास्थ्यकर्मी : (खून की रिपोर्ट को ध्यान से देखते हुये) राजू खून की रिपोर्ट को देखकर ऐसा लगता है कि तुम एचआईवी पॉजिटिव हो और तुम्हें एड्स होने की संभावना है।

राजू : यह क्या होता है? मैं कुछ समझा नहीं?

स्वास्थ्यकर्मी : तुम्हारे खून की जाँच में एचआईवी के विषाणु दिखाई दिये हैं, लेकिन यह सही है या नहीं, यह जानने के लिये हमें एक और जाँच करनी पड़ेगी। मैं तुम्हें एक मनोचिकित्सक के पास भेजने वाला हूँ, वह तुम्हें इस बीमारी के बारे में अच्छी तरह जानकारी देंगे। वह पीछे ही बैठते हैं।

सूत्रधार : यह सुनने के बाद राजू को कुछ सूझता है। वह फौरन स्वास्थ्य केन्द्र से बाहर निकलता है। उसको मनोचिकित्सक की भी जरूरत महसूस नहीं होती और न ही दूसरी जाँच की। वह अकेला ही भटकता रहा, उसकी ऑँखों में आंसू थे, जब तक उसका दोस्त संजू उसे नहीं मिला तब तक उसका भटकना जारी रहा।

संजू : राजू तू इधर क्या कर रहा है? और तेरी हालत तो काफी खराब दिखती है?

राजू : क्या बताऊँ यार? मेरे साथ एक भयानक हादसा हुआ है, मैं बहुत घबराया हुआ हूँ, मैं क्या करूँ? मुझे कुछ समझ में नहीं आ रहा है।

संजू : चल रे पगले चल, होटल में जाकर चाय पीते हैं और बैठकर बात करते हैं।

राजू : तुझे कैसे बताऊँ, मेरी समझ में नहीं आ रहा हे? एक दिन मैंने रक्तदान किया, उसके बाद वहाँ से मुझे बुलावा आया, वो कह रहे थे कि मुझे एड्स हो गया है।

संजू : राजू यार, मुझे यकीन नहीं हो रहा है, बोलने से पहले तुझे पक्का मालूम है, क्या ऐसा हो सकता है?

राजू : उसने मुझे और एक जाँच करवाने को कहा, लेकिन पक्का होने से पहले ही मैं वहाँ से भाग आया।

संजू : ठीक है यार, लेकिन ये सब हुआ कैसे? तेरा कहीं लफड़ा तो नहीं हुआ?

राजू : मुझे सचमुच कुछ नहीं पता मुझे ये सब कैसे हो गया? इसी के बारे में सोचकर भटक रहा हूँ। न ही मैंने किसी के साथ समलैंगिक संभोग किया है और न ही नशीली चीजों का सेवन किया है तो फिर मुझे एड्स हुआ तो हुआ कैसे?

सूत्रधार : दोनों कुछ देर तक ऐसे ही बात करते हैं और फिर वे अपने-अपने रास्ते निकल लेते हैं। शाम को संजू अपने दोस्तों से मिलता है।

राखी :क्या संजू सब कुछ ठीक तो है ना? क्या चल रहा है?

संजू : अरे यार मैं जो तुमको जो बताने वाला हूँ, उस बात पर तुम्हें विश्वास नहीं आएगा, अभी थोड़ी देर पहले मुझे राजू मिला था वो कह रहा था कि उसे एड्स हो गया है।

चिंगी : क्या तुझे ये नहीं मालूम था कि वो ड्रग्स लेता है - कैसे हुआ ये सब।

बंडया : या तो वह किसी आदमी के साथ सेक्स करता होगा या गया होगा किसी कोठे वाली के साथ।

पिंकी : राहुल की पार्टी में वो मेरे साथ था।

राखी : क्या तुमने उसको चूमा था?

पिंकी : मतलब? मुझे भी एड्स होगा?

बंडया : तुम डॉक्टर को क्यों नहीं दिखातीं पर उसके साथ कोई कैसे जा सकता है वो मुझे सबसे अलग लगता है। 
यारी दोस्ती

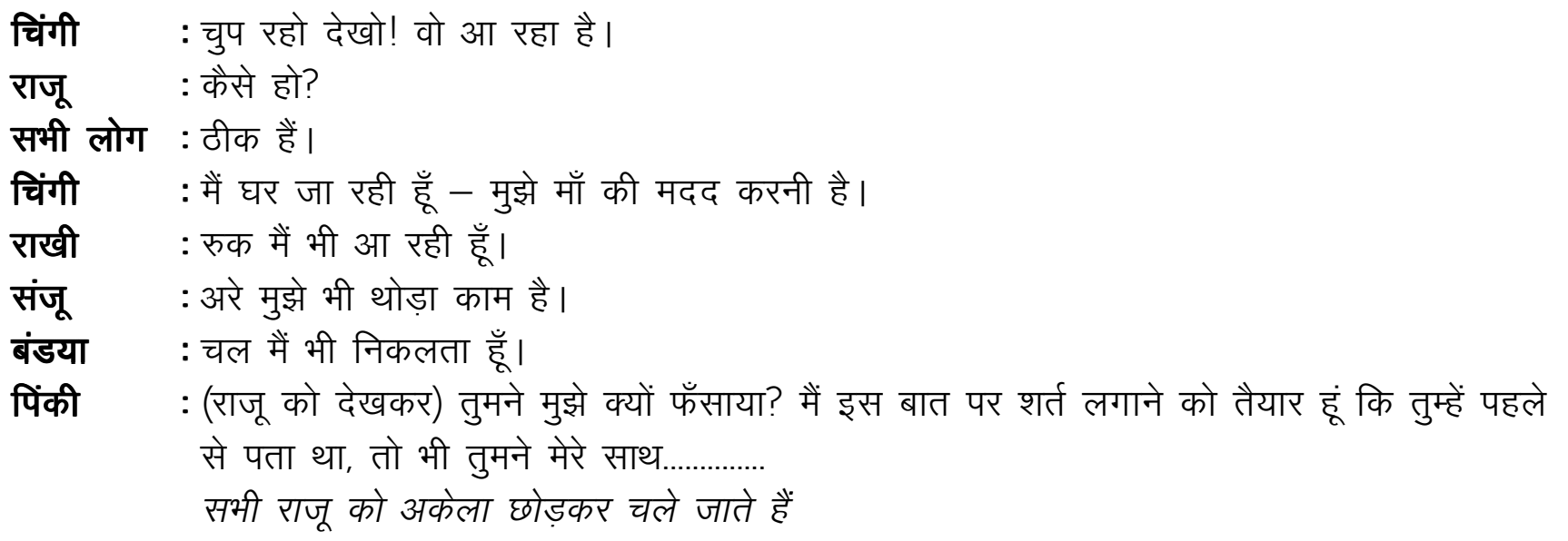

\section{संसाधन पत्रक : एड्स की कहानी}

एड्स की कहानी की शुरुआत 1980 में हुयी थी। इस दौरान अमेरिका तथा यूरोप में बहुत से लोगों में एक अजीब किस्म का चमड़ी का कैंसर "कापोसी सरकोआ" और "न्युमोनिया" के लक्षण दिखने लगे। इन सभी पुरुषों में जो समानता थी, और वह यह थी कि उन सभी में रोग प्रतिरोधक क्षमता कम होती चली गयी, और उनमें से बहुत से पुरुष मर गये। चूंकि, इनमें से ज्यादातर लोग समलैंगिक संबंध रखने वाले थे। इसलिये शुरू में यह समझा जा रहा था कि पुरुषों के साथ संभोग करने से ये बीमारी फैलती है। इसकी वजह से छल, भेदभाव, और पूर्वाग्रह की बहुत सी कथाओं ने जन्म लिया। लेकिन कुछ ही समय में नये मरीज सामने आये जो केवल समलैंगिक संबंध रखने वाले ही नहीं थे। सिरींज द्वारा, खास करके वह लोग जिन्होंने कभी खून चढ़ाया था, होमो-फिलीया के मरीज इत्यादि। इन सभी में समान लक्षण दिखने लगे। इन लक्षणों वाली बीमारियों को वर्ष 1982 में एक्वायर्ड इम्युनो डिफीसिअन्सी सिंड्रोम (एड्स), नाम दिया गया। अगले ही साल फ्रांसीसी वैज्ञानिकों ने इस बीमारी के वायरस को ढ़ंढ निकाला और उन्होंने इसको एचआईवी (हयूमन इम्यूनाडिफिसिाअन्सी वायरस) नाम दिया। संभोग के समय निरोध/कंडोम इस्तेमाल न करने से ये बीमारी फैलती है। दूषित खून के सम्पर्क में आने से यह बीमारी हो सकती है। यह मालूम होने पर भी, आज बहुत से लोगों को खुद की सुरक्षा के लिये क्या करना चाहिये? ये बात उन्हें पता ही नहीं हैं। एड़स किसी को भी हो सकता हैय चाहे वह औरत हो या मर्द, छोटा हो या बड़ा, अमीर हो या गरीब, किसी भी जाति-धर्म का हो, भिन्न लिंगी
संभोग करने वाले, समलिंगी संभोग करने वाले, और द्विलिंगी संभोग करने वाले को भी हो सकता है।

\section{यह एड्स क्या है?}

एड्स भी एक प्रकार का गुप्त रोग है। लेकिन यह यौन संबंधों के अतिरिक्त अन्य अनेक मार्गों से भी फैल सकता है। अन्य बीमारियों की तुलना में इसके कोई दिखने वाले लक्षण नहीं होते। एचआईवी का पता केवल खून की जाँच द्वारा ही चल सकता है।

\begin{tabular}{|l|l|}
\hline $\begin{array}{l}\text { एड्स्स (AIDS) का अर्थ है, एक्वायर्ड } \\
\text { इम्यूनोडिफिसिएन्सी सिन्ड्रोम }\end{array}$ \\
\hline एक्वायर्ड: & $\begin{array}{l}\text { अर्थात् दूसरे व्यक्ति से प्राप्त } \\
\text { करना। }\end{array}$ \\
\hline इम्यूनोडिफिसिएन्सी: & $\begin{array}{l}\text { बीमारियों के वायरस के } \\
\text { कारण शरीर की रक्षा करने } \\
\text { वाली शरीर की रोग } \\
\text { प्रतिरोधक क्षमता में कमी। }\end{array}$ \\
\hline सिन्ड्रोम: & बीमारियों के लक्षणों का समूह। \\
\hline
\end{tabular}

एचआईवी नाम के एक सूक्ष्म जीवाणु से एड्स होता है। यह जीवाणु शरीर की रोग प्रतिरोधक शक्ति पर हमला करते हैं। जिसके कारण मरीज को अन्य बीमारियों का शिकार होने की संभावना बढ़ती है। इससे मृत्यु भी हो सकती है। ये बीमारी बैक्टीरिया, वायरस एवं अन्य पैरासाईट की वजह से होती हैं 


\section{एड्स ऐसे फैलता है}

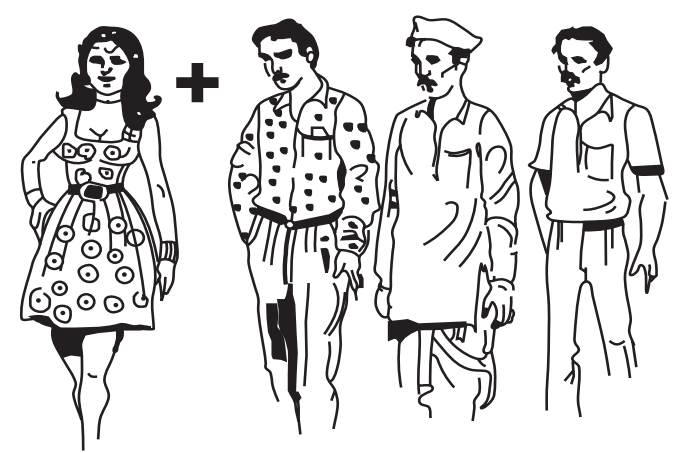

स्त्री + पुरुष 1, पु. 2 , पु. 3

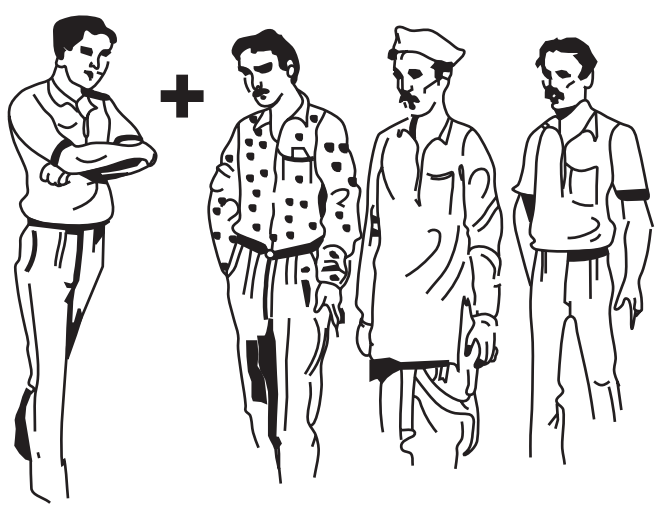

पुरुष + पुरुष 1 , पु. 2 , पु. 3

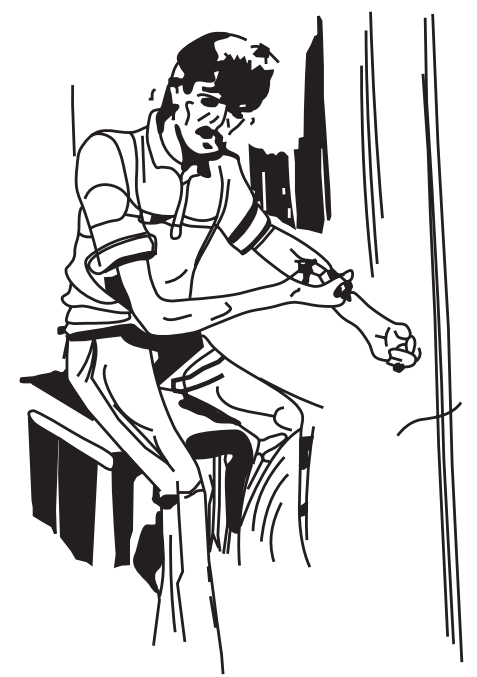

शिराओं से मादक द्रवों का सेवन

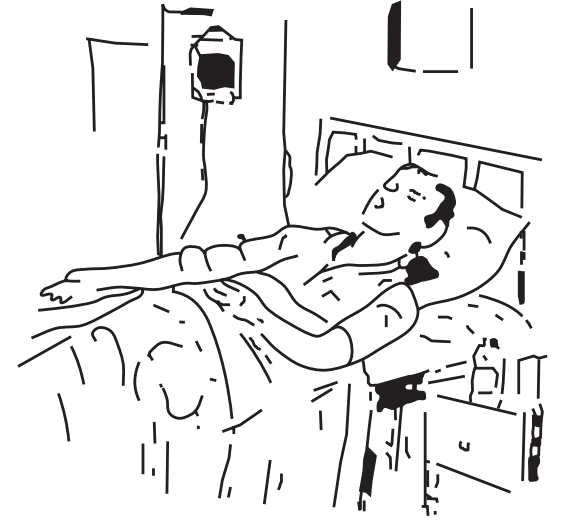

एच.आय.वी. ग्रसित रक्त का चढ़ाया जाना

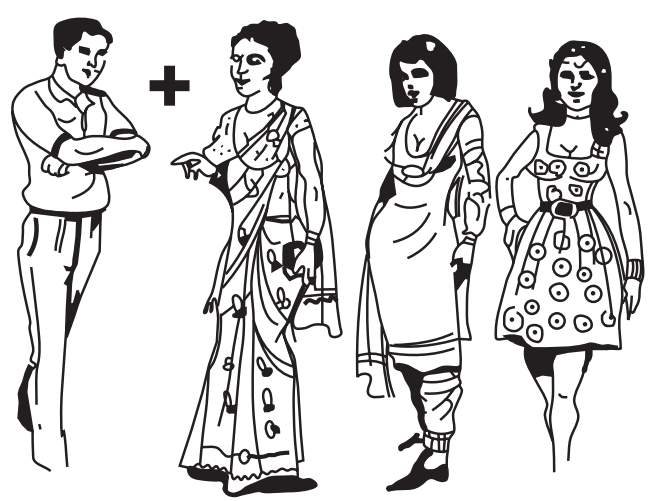

पुरुष + स्त्री 1 , स्त्री 2 , स्त्री 3

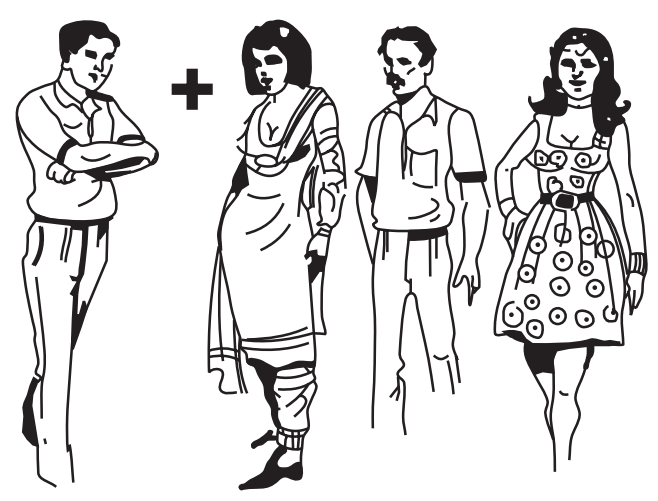

पुरुष + स्त्री 1 , पुरुष 2 , स्त्री 3

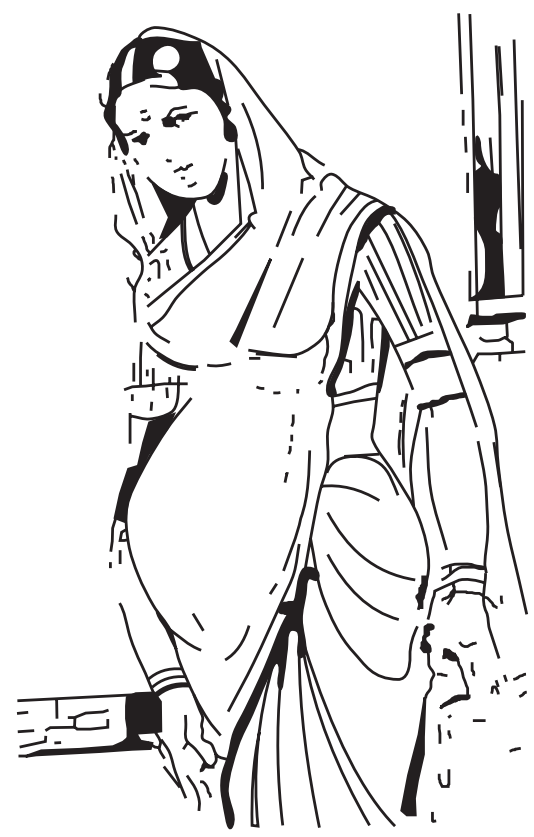

एच.आय.वी. ग्रसित गर्भवती रत्री से बच्चे में 


\section{एचआईवी तथा एड्स कैसे फैलता है?}

यौन संबंध - योनि और पिछले हिस्से से संबंध स्थापित करने से इस जीवाणु का फैलाव होता है, क्योंकि ये जीवाणु धात और योनि द्रव में पाए जाते हैं, इसलिये किसी भी तरह के संबंध में कंडोम का इस्तेमाल करना चाहिये।

दूषित सिरिंज के इस्तेमाल द्वारा - एचआईवी संक्रमित व्यक्ति द्वारा नशा करने के लिये इस्तेमाल की जाने वाली सिरिंज / इंजेक्शन को किसी दूसरे व्यक्ति द्वारा इस्तेमाल करने से यह वायरस फैल सकता है। इसी कारण सुई / सिरिंज को केवल एक ही बार इस्तेमाल करने की सलाह दी जाती हे या फिर दुबारा इस्तेमाल करने से पहले उसे संक्रमण मुक्त करने के लिये कहा जाता है।

संक्रमित खून चढ़वाने से - अगर रक्तदाता एचआईवी संक्रमित हो तो उसके खून द्वारा खून चढ़वाने वाले व्यक्ति के शरीर में यह वायरस पहुँच जाता है। एड्स के बारे में खून की जाँच हर रक्तदाता को करवानी चाहिये। खून जमा करने वाली थैली या बॉटल पर एचआईवी टेस्टेड का निशान लगाना जरूरी है, तथा इनका सख्ती से पालन करना चाहिए।

संक्रमित माँ द्वारा बच्चे में - इस तरह के संक्रमण, माँ से उसके होने वाले बच्चे को हो सकते हैं। बच्चा जन्म लेते समय उस बीमारी की चपेट में आ सकता है। बच्चा पैदा
करने का निर्णय एचआईवी जाँच करा लेने के बाद ही दोनों (स्त्री-पुरुष) को मिल कर करना चाहिये।

(एआरवी ड्रग्स) एड्स की दवाइयाँ - दुर्भाग्यवश अभी तक एड्स को पूर्णरूप से ठीक करने वाली दवाइयाँ नहीं बनी हैं। जो अब तक मिली भी हैं, वो मरीज का जीवन बढ़ाने वाली दवाइयाँ नहीं हैं, यह सिर्फ शरीर की रोग प्रतिरोधक क्षमता को कृत्रिम रूप से सुदृढ़ बनाने का प्रयास करती हैं। 1995 से दवाईयों का एक मिश्रण जिसे कॉकटेल कहते हैं, दी जाती हैं। तथा इन्हें अन्टी-रेट्रोव्हायरल (ARV) दवाईयों के नाम से दिया जाता है।

\section{प्रेरक के लिए}

अन्टी-रेट्रोव्हायरल (ARV) दवाईयॉ काफी महंगी आती है। एआरवी के लिए सरकारी अस्पताल में संपर्क करना चाहिए हालांकि यह कुछ चुनिंदा दवा की दुकानों पर भी उपलब्ध है। सरकार ने इस दवा को एचआईवी पीड़ित लोगों तक आसानी से पहुँचाने के लिए इसकी कीमत को वास्तविक कीमत से काफी कम रखा है, फिर भी यह इलाज का एक महंगा तरीका है। हाल के दिनों में बहुत से गैर सरकारी संस्था सस्ते दामों पर एआरवी उपलब्ध करा रहे हैं पर जरूरत है इसे व्यापक प्रसार करने की ताकि यह जरूरतमंद लोगों तक आसानी से पहुँचे। 


\section{एड्स ऐसे नहीं फैलता है}

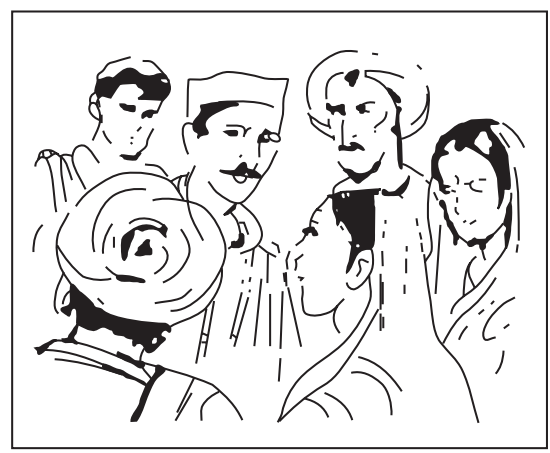

सामूहिक चर्चा से

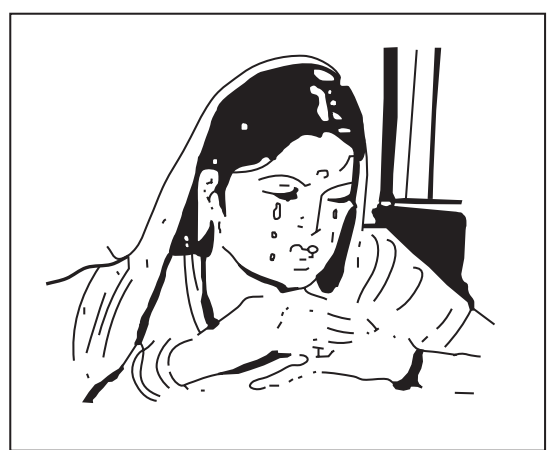

आँसुओं से

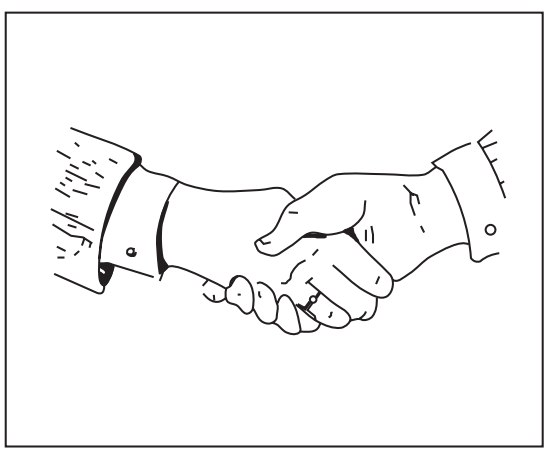

हाथ मिलाने से

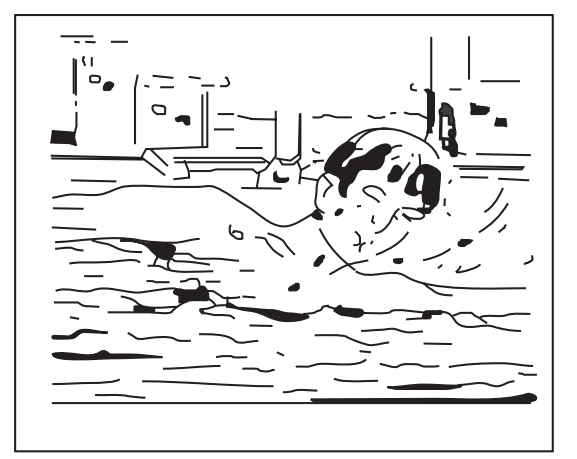

तरणताल/तालाब का उपयोग करने से

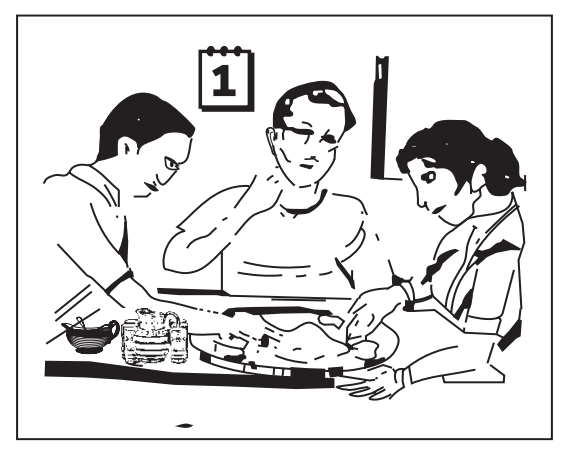

एक साथ खाने से

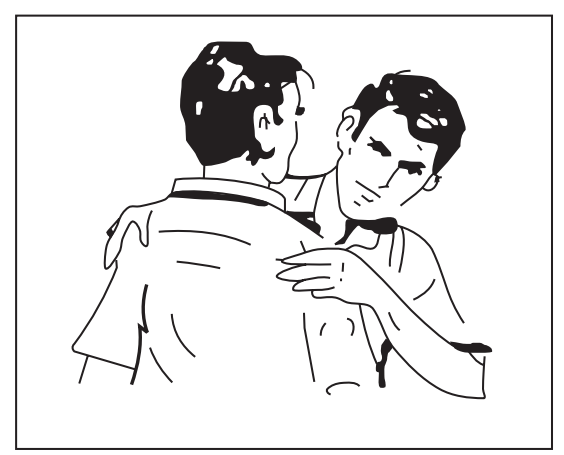

आलिंगन से

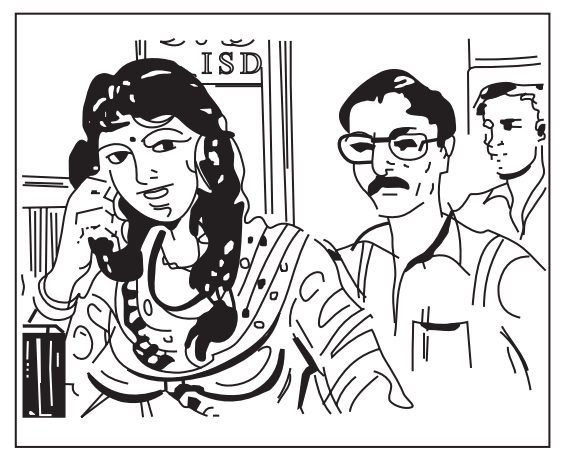

सार्वजनिक टेलिफोन का उपयोग करने से

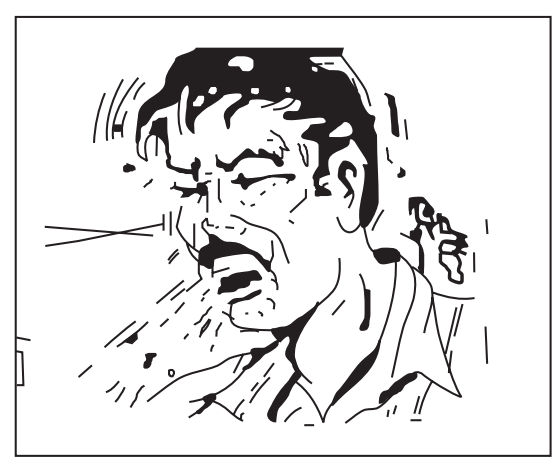

खाँसने से

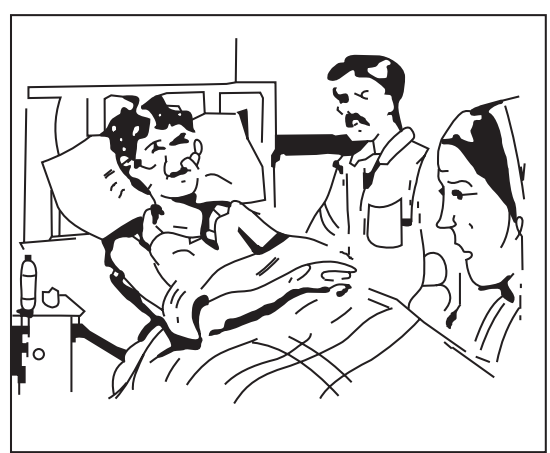

एच.आय.वी. एडस् व्यक्ति की सेवा करने से

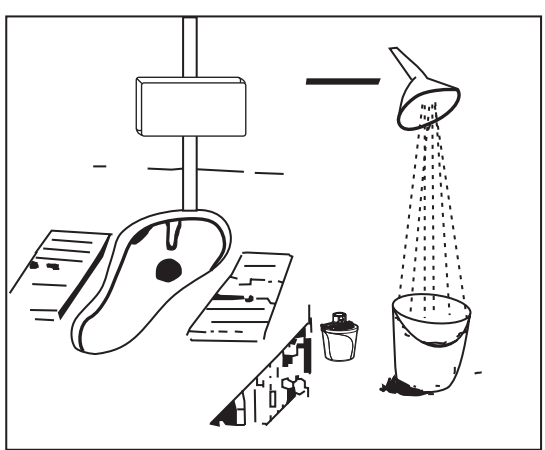

एक ही शौचालय का उपयोग करने से

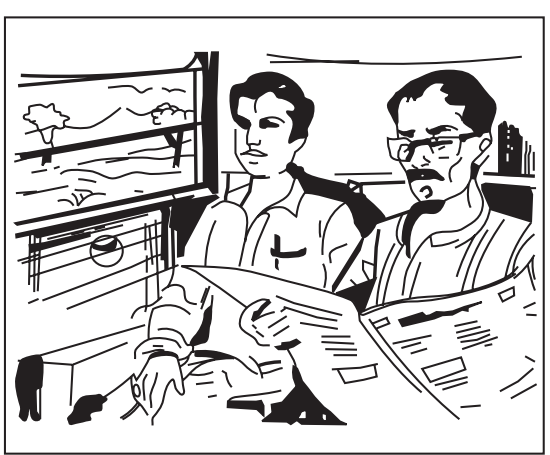

एक साथ यात्रा करने से

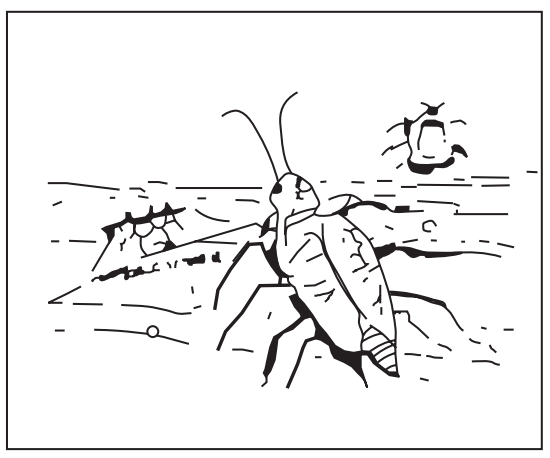

मच्छर/खटमल के काटने से

स्रोतः भतलवंडे और गंगाखेड़कर, यौवन की दहलीज़ पर, 2002, यूनिसेफ 
उद्देश्य: इस अभ्यास में एचआईवी तथा एड्स और गुप्तरोग कैसे तेजी से फैल सकते हैं और हम उसे कैसे टाल सकते हैं, कैसे बच सकते हैं, यह बताने का प्रयास किया गया है। साथ में यह भी चर्चा की गयी है कि दोस्तों का दबाव किस प्रकार से व्यवहार को प्रभावित करता है।

सामग्री: बड़े आकार के पोस्ट कार्ड पेपर, जो चिपकाए जा सकते हों एवं पेन।

समय: एक घंटा

\section{प्रक्रिया}

अभ्यास शुरू करने से पहले, 3 कार्डों पर C लिखें, 3 अन्य कार्डों पर "भाग नहीं लेना है तथा किसी भी निर्देश का पालन न करें जब तक हम बैठ न जाए' लिखें, एक कार्ड पर $\mathrm{H}$ लिखें तथा बचे हुए कार्ड्स $(\mathrm{C}$ और $\mathrm{H}$ भी) पर "मेरे निर्देशों का पालन करें' लिखें।

- सभी प्रतिभागियों को एक-एक कार्ड दें, और उन्हें बताएं कि, कार्ड पर जो लिखा है, वह किसी को भी बताना नहीं है और केवल कार्ड में लिखे निदेर्शों का पालन करना है।

- फिर प्रत्येक प्रतिभागी को खड़े होकर तीन अन्य लोगों के दस्तखत लेने के लिए कहें।

- जब सभी लोगों ने दस्तखत ले लिए हों तो उन्हें बैठने के लिए कहिये।

- जिस किसी प्रतिभागी के कार्ड पर $\mathrm{H}$ लिखा है उस व्यक्ति को खड़े रहने के लिए कहिये।

- जिन लोगों ने इस व्यक्ति का दस्तखत लिया है उन्हें खड़ा कीजिये। इन व्यक्तियों के कार्डों पर जिन्होंने भी दस्तखत किया है, उनको भी खड़ा
कीजिये। यह प्रक्रिया उस समय तक चालू रखिए, जब तक कि सभी खड़े न हो जाएं, केवल उन्हें छोड़ कर, जिन्होंने इस अभ्यास में हिस्सा ही न लिया हो।

- $\mathrm{H}$ कार्ड वाले सदस्य से कहिए कि वह कल्पना करे कि उसे एचआईवी या यौन रोग हुआ है तथा पहले तीन व्यक्ति जिनका उसने दस्तखत लिया है, उनके साथ उसने असुरक्षित यौन संबन्ध बनाया है। इस बात पर जोर दें कि, यह केवल एक कल्पना है एवं उसमें सच्चाई नहीं है।

- जिनके कार्डं पर भाग न लें लिखा है, उन्हें यह कल्पना करने को कहें कि उन्होंने संभोग नहीं किया है तथा उन्हें बैठने को कहिये।

- इसी तरह C लिखे हुए कार्ड के लोगों से यह कल्पना करने को कहें कि उन्होंने कंडोम/निरोध का इस्तेमाल किया है। इसलिए उन्हें एचआईवी/यौन रोग होने का खतरा कम है। अतः $\mathrm{C}$ कार्ड वालों को भी बैठने को कहिये।

- अब नीचे दिए हुए सवालों के आधार पर चर्चा करें। 


\section{चर्चा के मुद्दे}

- $\mathrm{H}$ कार्ड वाले व्यक्ति को कैसा लगा? जब उसे पता चला कि उसे एचआईवी है, और तब उसकी प्रतिक्रिया क्या थी?

- $\mathrm{H}$ कार्ड वाले व्यक्ति के प्रति अन्य प्रतिभागियों की प्रतिक्रिया थी?

- अभ्यास की शुरूआत से जो लोग शामिल नहीं थे उन्हें कैसा महसूस हुआ? क्या अभ्यास के दौरान उनकी भावनाओं में बदलाव आया? अन्य प्रतिभागियों की प्रतिक्रिया इन लोगों के प्रति कैसी थी?

- जब सभी लोग ऐसे कार्यक्रमों में शामिल होते हैं, तो क्या ऐसे कार्यक्रमों में शामिल न होना आसान है या मुश्किल? और क्यों?
- ऐसे लोगों की क्या प्रतिक्रिया थी जिन्होंने $\mathrm{H}$ कार्ड वाले प्रतिभागी के कार्ड पर दस्तखत किया था, उनको कैसा लगा जब उन्हें यह पता चला कि उनको भी एचआईवी संक्रमण हो चुका है।

- $\mathrm{H}$ कार्ड वाले व्यक्ति को नहीं पता था कि वह एचआईवी संक्रमित / पॉजिटिव है। उसको इस बात का पता कैसे लगा?

- कई बार ऐसा भी हो सकता है कि 'भाग ना लें' वाले प्रतिभागी भी दूसरों का दस्तखत ले लेते हैं या कुछ अन्य प्रतिभागी 'भाग ना लें' वाले प्रतिभागियों का दस्तखत ले आते हैं। इस व्यवहार की व्याख्या 'दोस्तों के दबाव' में होने वाले व्यवहार के रूप में करें। 

अभ्यास 4.3

\section{मुझे भी यह हो सकता है यदि...}

सारांशः इस अभ्यास द्वारा युवकों को उन परिस्थितियों को समझने में मदद मिलेगी जिनमें उन्हें एचआईवी संकमित होने का खतरा है। यह परिस्थितियां व्यक्तिगत, सामाजिक एवं कार्यक्रमों के स्तर पर निर्भर करती हैं।

उद्देश्य: युवकों के जीवन में आने वाली उन परिस्थितियों के बारे में चर्चा करना जिनकी वजह से उन्हें यौन रोग अथवा एचआईवी हो सकता है।

समयः एक घंटा

सामग्री: पेपर, पेन्सिल, कुछ वाक्यों की सूची।

पुरुषों में मर्द होने के नाते जो अपेक्षायें या जिम्मेदारियां होती हैं उन्हें निभाने का तनाव उन पर बना रहता है। साथ ही उनमें अपनी भावनाओं तथा अपने जज्बातों को समझने एवं उनका निवारण करने की क्षमता कम होती है। ऐसे में युवाओं को इस तरह की जानकारी देने वाले कार्यक्रमों का अभाव ही गुप्तरोग और एचआईवी तथा एड्स के खतरे को बढ़ाते हैं।

- अभ्यास के आरम्भ में यह बताएं कि, कैसे कुछ परिस्थितियां हमें खतरे में डाल देती हैं। उदाहरण के तौर पर, एक व्यक्ति जिसे यह नहीं मालूम कि निरोध के बिना संभोग करने पर एचआईवी/यौनरोग हो सकता है, उस व्यक्ति की अपेक्षा अधिक खतरे में है जिसे इस बात की जानकारी है।

- चार-चार युवाओं का समूह तैयार करें। युवाओं को कौन-कौन से हालात में ज्यादा खतरा हो सकता है, यह वर्णन करने वाला एक वाक्य हर एक समूह को दिया जायेगा।

\section{समूह को दिये जाने वाले वाक्य}

- यदि मुझे यह नहीं मालूम कि यौन-स्वास्थ्य का ध्यान कैसे रखूं तो मुझे खतरा हो सकता है।

- अगर मैं जैसा महसूस करता हूं वैसा नहीं कह सकता तो मुझे खतरा हो सकता है।

- अगर मैंने हस्तमैथुन किया तो मेरी मदांनगी खतरे में आ सकती है।

- यदि मैं अपने लिए स्वयं नहीं सोच सकता, तो मुझे खतरा हो सकता है।

- दोस्तों के दबाव में आकर अगर मैं कोई दु:साहस करने की कोशिश करता हूं तब मुझे खतरा हो सकता है।

- मेरे पास मदद करने वाला कोई विश्वसनीय व्यक्ति नहीं है, तो मुझे खतरा हो सकता है। 


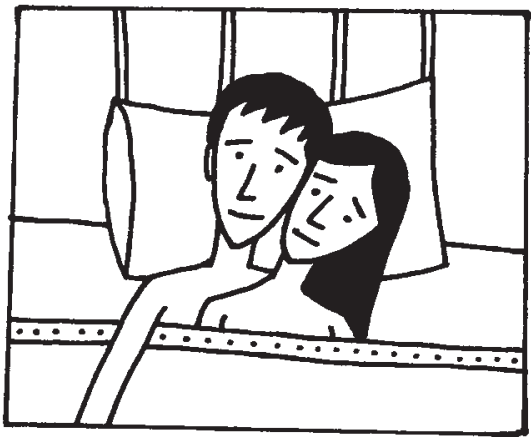

- मुझे कुछ नहीं होगा जब मुझे ऐसा लगता है, तब मुझे खतरा हो सकता है।

- मैं उसको अच्छा लगूं, इसलिए मैं कुछ भी करता हूं, तब मुझे खतरा हो सकता है।

- जब मैं किसी भी परिस्थिति में सेक्स करना चाहता हूं तो मुझे खतरा हो सकता है।

- जब खुद के यौन-जीवन की जिम्मेदारी मैं नहीं लेता, तब मुझे खतरा हो सकता है।

- प्रत्येक समूह को अपने-अपने वाक्य/लाइन पढ़ने को कहें तथा उससे क्या अर्थ निकलता है, इस पर चर्चा करें। यह भी चर्चा करें कि इस वाक्य से वह सहमत है या नहीं? और क्यों?

- चर्चा खत्म होने पर समूह को एक प्रतिनिधि का चुनाव करना है। प्रतिनिधि को वह वाक्य और समूह चर्चा का निष्कर्ष, सभी को बताना है।

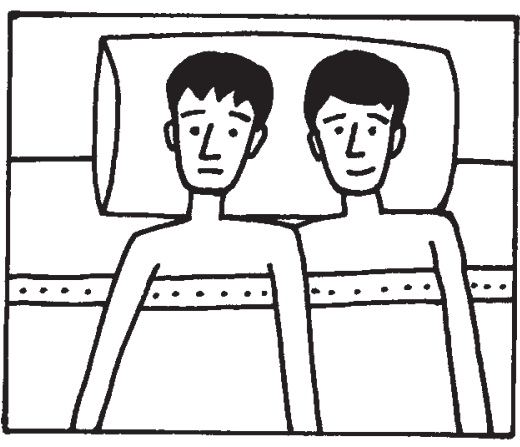

चर्चा के मुद्दे

- युवकों को एचआईवी तथा एड्सका खतरा हो सकता है, क्या आपको ऐसा लगता है?

- किन हालातों में यह खतरा होता है?

- किसी संबंध में, वे कौन से कारण हैं जिनकी वजह से हमें इन रोगों के संसर्ग में आने का खतरा होता है?

- अपनी संस्कृति के वे ऐसे कौन से कारण हैं, जिनकी वजह से युवकों/युवतियों को एचआईवी संक्रमण होने की संभावनायें रहती हैं या खतरा बढ़ जाता है?

- आपके इलाके में युवकों के लिये स्वास्थ्य सेवा उपलब्ध है या नहीं? कौन सी? और कहाँ?

- एचआईवी तथा एड्स और नशीले पदार्थों का सेवन जैसे सवालों का सामना करने के लिए तैयार किये हुए कुछ शैक्षणिक कार्यक्रम कौन से हैं?

\section{अन्त में}

- वह कौन से कारण हैं जिनके कारण पुरुष अपना ध्यान नहीं रखते हैं?

- इस बात पर भी चर्चा करें कि, युवकों को खतरा अन्य वजहों से भी हो सकता है। जैसे कि-युवकों के लिए जागरूकता कार्यक्रमों का अभाव। 
अभ्यास 4.4

\section{कुछ लोग कंडोम का इस्तेमाल ही नहीं करना चाहते क्योंकि ...}

सारांश : पुरूषों को कंडोम के सही प्रयोग की विधि बताने के अतिरिक्त यह अभ्यास युवकों को इस बात की भी जानकारी देता है, कि आपसी रिश्ते में कंडोम के प्रयोग को लेकर किस प्रकार बात करनी चाहिए।

उद्देश्य : इस विश्वास को तोड़ना कि, कंडोम के प्रयोग से सेक्स सन्तुष्टि नहीं मिलती है, एवं लिंग के उत्तेजित होने में परेशानी होती है। साथ ही कंडोम के सही इस्तेमाल की जानकारी देना और निरोध, के इस्तेमाल को बढ़ावा देना।

समय : 2 घटें

सामग्री : कार्ड्स, छोटे बक्से। पुरूषों का कंडोम, रबर का लिंग (प्रतिकृति) या लिंग जैसी कोई भी वस्तु।

प्रक्रिया

- जरूरत है कंडोम को एक नया स्वरूप देने की। जिसमें कि कंडोम के इस्तेमाल का संबंध न केवल सिर्फ बीमारियों से बचने के बारे में बल्कि यौन संबंध से मिलने वाले सुख से जोड़ने का प्रयास भी करना होगा।

- कंडोम का इस्तेमाल करते समय आने वाली समस्याओं पर खुलेपन से विचार करें, तथा चर्चा के अंत में सभी युवकों को एक-एक कंडोम दें, ताकि उनका विचार इसके प्रयोग के बारे में और सुदृढ़ हो सके।

- सभी युवाओं को एक-एक कार्ड दें तथा सेक्स और कंडोम के इस्तेमाल से सम्बन्धित जो भी उन्होने सुना हो अथवा कोई भी शब्द, वाक्य या कल्पना, उसे इस कार्ड पर लिखने को कहें।
- समूह के सामने एक बक्सा रखें, शुरूआत में उनके द्वारा लिखे हुये सभी कार्डों को बक्से में डालने को कहें। फिर समूह में से प्रत्येक प्रतिभागी को सामने बुलायें और बक्से में से एक कार्ड निकालकर सबसे सामने जोर से पढ़ने के लिये कहें और वह वाक्य, शब्द या कल्पना सही या गलत है, इस पर समूह में चर्चा करें या बताने के लिये कहें।

- इसके बाद पुरूषों के द्वारा इस्तेमाल किया जाने वाला कंडोम सभी को दिखायें तथा कंडोम खरीदते वक्त कौन सी बातों का ध्यान रखना चाहिये, यह समझायें। फिर कंडोम ठीक तरह से कैसे इस्तेमाल करते हैं, यह भी दिखायें। यह समझाकर दिखाने के लिए हम केला या रबर के लिंग के आकार की कोई वस्तु या चीज का इस्तेमाल कर सकते हैं। 
- पुरूष को कंडोम के बारें में जानकारी देने के बाद, स्त्रियों को कंडोम का इस्तेमाल कैसे करते है? यह दिखायें (यदि साहित्य उपलब्ध है तो)। इसके लिये पारदर्शक प्लास्टिक कप का प्रयोग कर सकते है, इससे यह कंडोम स्तिर्रियों की योनि में कैसे लगाते हैं इसकी जानकारी मिलेगी।

- दो या दो से अधिक युवाओं को नाटक करके दिखाना है। इस नाटक के माध्यम से हम कंडोम को इस्तेमाल करते समय हमें सामान्य तौर पर कहॉ-कहॉ समस्यायें आतीं हैं, उसे बताने का प्रयास करेंगे, और नाटक के जरिये ही उन समस्याओं का हल खोजने का प्रयास करेंगे।

\section{चर्चा के मुद्दे}

- क्या कारण है कि युवा वर्ग कंडोम का इस्तेमाल नहीं करना चाहता? यह जानते हुए भी कि कंडोम प्रयोग करना चाहिए, जब असली मौका आता है तो वह उसका प्रयोग क्यों नहीं करते?

- आप कंडोम इस्तेमाल करने वाले हैं, यह किसी युवती को कैसे बतायेंगे?

- किसी औरत ने कंडोम इस्तेमाल करने को कहा और आपके पास कंडोम नही है तो उस समय आप क्या करेंगे?

- और, अगर युवती ने ऐसा कहा, कि यदि आप के पास कंडोम है तो ही मैं यौन संबंध के लिये तैयार हूं। तो आप क्या सोचेंगें? आपको क्या महसूस होगा?

- सेक्स के समय यदि एक युवती यह कहती है कि उसके पास कंडोम है जिस का प्रयोग हो सकता है, तो कंडोम रखने वाली युवती के प्रति आप क्या सोचेंगे या उसके प्रति आपकी धारणा क्या होगी?
- स्त्री कंडोम के बारे में आप का क्या ख्याल है? क्या उसे इस्तेमाल करने वाली युवती के साथ आप यौन संबंध रखेंगे?

\section{पुरूष कंडोम}

- पुरूष कंडोम यह बहुत ही पतले एवं मजबूत रबड़ से बनाया जाता है। इसलिये सही तरीके से इस्तेमाल करने की जानकारी होने पर यह बहुत ही कम फटता है।

\section{कंडोम कैसे इस्तेमाल करें?}

- कंडोम का पैक खोलने से पहले ऊपर दी गई तारीख देख लें, वह समाप्ति की तारीख से आगे का तो नहीं है अथवा समय सीमा समाप्त हो नहीं हो गयी है, कहीं वह कटा-फटा तो नहीं है, उसमें कहीं छिद्र तो नहीं है तथा उसे स्पर्श करने पर चिकनाई लगती है या नहीं, यह सब बातें जाँच लें।

- कंडोम लगाने से पहले पुरूष का लिंग उत्तेजित होना जरूरी है, उसका लिंग सीधा होना भी जरूरी है। कंडोम सही तरीके से लिपटा है। इस बात की तसल्ली कर लीजिये तथा वीर्य जमा होने के लिए कंडोम में जो छोटी से जगह होती है, वह तैयार हुयी है या नहीं, ये देख लें। उसमें जो हवा होती है उसे बाहर निकाल दीजिये और पूरी तरह से लिंग पर कंडोम चढ़ा लीजिये।

- संभोग के तुरन्त बाद जब लिंग उत्तेजित हो तभी कंडोम को उतार देना चाहिए, नहीं तो वीर्य बह कर योनि में जा सकता है। 


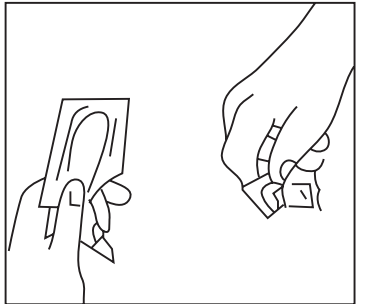

1. कण्डोम को पैकेट में से निकालिए। कण्डोम के अगले सिरे में से हवा निकालने के लिए उसे उंगली और अंगूठे के बीच में पकड़ कर हलके से दबाइए और पकडे रखिए।

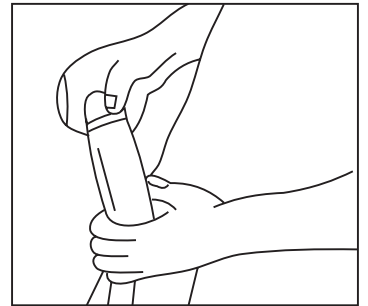

2. दूसरे हाथ से कण्डोम को उत्तेजित लिंग के ऊपरी सिरे पर रखिए और कण्डोम के छल्ले को खिसका कर खोलते हुए पूरे लिंग के ऊपर पहना दीजिए।

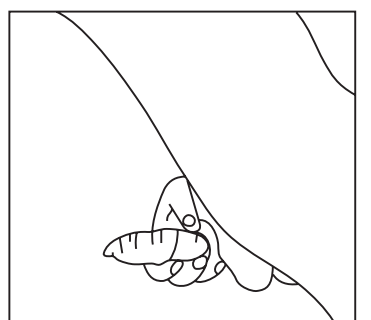

4. वीर्यपात के तुरंत बाद, जब लिंग उत्तेजित हो उसी दरमियान लिंग बाहर निकाल दीजिए, उस वक्त कण्डोम का छल्ला पकड़े रखिए ताकि कण्डोम उतर न जाए।

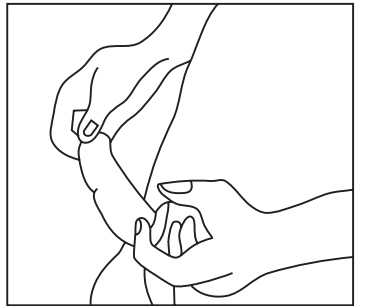

3. जब कण्डोम को छल्ला लिंग की जड़ तक पहुँचा जाए तब (योनि में) प्रवेश कर सकते हैं।

\section{अंत में}

- पहले संभोग के दौरान किसी जवान पुरूष का तनाव में आना अथवा शर्म महसूस करना, यह कोई बुरी बात नहीं है। यह डर स्वाभाविक है और इस समय कंडोम का इस्तेमाल करना और भी ज्यादा कठिन हो जाता है। उनकी इन सभी भावनाओं, समस्याओं तथा डर के बारे में विस्तार से चर्चा करें।

- कंडोम इस्तेमाल न करने संबंधी जो विचारधारा बनी हुई है उसे तोड़ने के लिये युवाओं के साथ कार्य कीजिये तथा उन सभी विचारधाराओं, जैसे कंडोम का इस्तेमाल करना कागज के साथ चाकलेट चखने के बराबर है या बरसात का मजा छतरी लगाकर घूमने में नहीं है, आदि के बारे में खुलेपन से चर्चा कीजिये।

- यह स्पष्ट है कि सुरक्षित संभोग / सेक्स केवल कंडोम का प्रयोग करने मे ही है, चाहे वह मुख मैथुन ही क्यों न हो।

- चर्चा करें कि यह प्रमाणित आंकड़ों द्वारा स्पष्ट हो चुका है कि, एक ही व्यक्ति के साथ (चाहे वह कोई भी हो) होने वाले यौन संबंधों में कंडोम के इस्तेमाल पर ज्यादा ध्यान नहीं दिया जाता इसकी वजह से यौन रोग तथा एचआईवी होने का खतरा बढ जाता है। आजकल विवाहित स्त्रियों मे एचआईवी का फैलाव होने का प्रमाण दिन पर दिन बढ रहा है। इसकी जानकारी समूह को दीजिये कि, पति-पत्नी के बीच नियमित संभोग क्रिया में भी कंडोम के इस्तेमाल की समस्याओं पर चर्चा करें। यह चर्चा समलैगिंक संबंध रखनेवाली जोड़ी के लिये भी है।

- कंडोम का इस्तेमाल किसी भी बीमारी तथा यौन संक्रमण से बचाव का अत्यंत प्रभावी और प्रतिरोधक उपाय है।

- प्रतिरोधक और गर्भ निरोधक के लिए स्त्री कंडोम एक अच्छा प्रयास है। यह बतायें कि, उसे कैसे इस्तेमाल किया जा सकता है? यह भी बतायें कि कुछ देशों में यह कंडोम उपलब्ध नहीं हैं, लेकिन जिन देशों में यह उपलब्ध है, वहाँ ज्यादातर पुरूषों को इसके बारें मे जानकारी ही नहीं होती है।

- संभोग करने से पहले स्त्री या पुरूष कौन सा कंडोम इस्तेमाल करना चाहते हैं, इसके बारें में चर्चा करना महत्वपूर्ण है, यह बात प्रतिभागियों को बतायें। 
अभ्यास 4.5

चाहिये ... नहीं चाहिये ? चाहिये ? नहीं चलेगा, जाने दो

सारांश : इस अभ्यास की मदद से इस बात का पता चलता है कि युवाओं की कंडोम के प्रति क्या विचारधारा है?

उद्देश्य : स्त्री-पुरूष और पुरूष-पुरूष रिश्तों में सुरक्षित यौन संबंधों की मांग करते समय आने वाली बातों/स्थितियों को युवाओं के सामने प्रस्तुत करना। कंडोम के इस्तेमाल संबंधी चर्चा करना और सुरक्षा उपायों पर चर्चा करना।

समय : 2 घंटे।

सामग्री : बड़े कागज, मार्कर पेन, चिपकने वाली पट्टी।

प्रक्रिया

- प्रतिभागी युवकों के चार समूह बनायें। प्रत्येक समूह को अलग-अलग नंबर दें, इस कार्यक्रम का उपयोग हम मिश्रित समूह के लिये भी कर सकते हैं तथा पुरूषों के साथ संबंध रखने वाले पुरूषों के लिये भी कर सकते है।

- प्रत्येक समूह को अपना-अपना काम करने के लिये 5 मिनट का समय दिया जायेगा।

\section{चर्चा के विषय}

समूह क्र 1 पु. 1 पुरूष कंडोम क्यों इस्तेमाल करना चाहते हैं?

समूह क्र 2 पु. 2 पुरूष कंडोम क्यों इस्तेमाल नहीं करना चाहते?

समूह क्र 3 म. 1 औरतें कंडोम क्यों इस्तेमाल करना चाहतीं है।
समूह क्र 3 म. 2 औरतें कंडोम क्यों इस्तेमाल नहीं करना चाहती?

समूह क्र 1 समलिंगी संबंधों में कंडोम का इस्तेमाल क्यों नहीं करना चाहतीं?

समूह क्र 2 समलैंगिक संबंधों में कंडोम का इस्तेमाल क्यों नहीं करना चाहिये?

- सभी समूहों को दिये गए मुद्दों पर चर्चा करने के लिये कहें। सभी समूह अपने-अपने मुद्दों पर चर्चा करेंगे। जिन्हें स्त्रियों के मुद्दों पर चर्चा करनी है, वह स्त्री भूमिका में प्रवेश कर चर्चा करेंगे।

\section{अब पहली चर्चा शुरू होगी}

समूह क्र 1 पु. 1 - कंडोम इस्तेमाल करने वाले पुरूष। 
समूह क्र 2 म. 2 - स्त्रियों के उस समूह को "जो कंडोम इस्तेमाल नहीं करना चाहती" को कंडोम के प्रयोग के बारे में राजी करेगा। इस विचार विमर्श में यह कल्पना करनी होगी कि दोनों समूह संभोग के लिए तो तैयार हैं पर कंडोम के प्रयोग को लेकर उनमें मतभेद हैं।

दोनों समूहों में बातचीत हो जाने के बाद, चर्चा करें कि उन्हें कैसा महसूस हुआ? उन्हें कौन सी नयी बात पता चली?

\section{चर्चा में होने वाले सवाल जवाब}

सभी समूह मिलकर चर्चा मे उठाये गए मुद्दों पर विचार करेंगे।

जो यहां पर किया गया, क्या वास्तविक जीवन में भी वैसा ही होता है? असफल चर्चा के क्या परिणाम होते हैं? कंडोम का प्रयोग नहीं करने वाले कारणों पर विशेष ध्यान देना आवश्यक है। इन कारणों पर पुर्नविचार होना चाहिये।

- इस प्रकार चर्चा करें कि, "कंडोम का प्रयोग हो" इस बात के समर्थन में सभी सदस्य आगे आये। अगर संभव हो तो यह चर्चा तीसरे दौर में भी रख सकते हैं। इसमें नये मुददों का का भी समावेश होना चाहिये।

- कंडोम का प्रयोग करना चाहिए या नहीं? इस निर्णय के कई कारण अलग-अलग स्तरों पर
प्रभावित करते हैं। जैसे कि, लिंग, संवाद करने का तरीका, भावनायें, आपसी आकर्षण, स्वाभिमान, खुद का अनुभव इत्यादि। ऐसे कुछ कारण और भी हैं, जिनके कारण पुरूष कंडोम का प्रयोग नहीं करना चाहता है। जैसे कि, साथी को खोने का डर या स्वाभिमान का अभाव इन वजहों से सत्री असुरक्षित यौन संबंधो के लिए तैयार हो जाती है। कंडोम का इस्तेमाल करें या नहीं करें? यह निर्णय ज्यादातर पुरूष इस वजह से भी लेता है कि वह किसके साथ संभोग करने वाला है। जैसे कि, किसी पुराने साथी के साथ, सहेली के साथ या वेश्या के साथ।

- आखिर में, कंडोम का इस्तेमाल करने संबंधी चर्चा करने के लिए उचित समय कौन सा हो सकता है? संभोग के ठीक पहले चर्चा करने से बेहतर है कि इस बात की चर्चा काफी पहले कर लेनी चाहिए।

- समलिंगी (MSM) संबंधों के बारे में क्या हम खुलकर चर्चा करते हैं? अगर हाँ, तो क्या यह लोग इस तरह के संबंध रखते हुए पाये गये हैं? क्या हमारी पहचान के लोग इस तरह के संबंधों में होते हैं? पुरूष-स्त्री और पुरूष-पुरूष इस तरह दोनों सहभागियों से संबंध रखनेवाले पुरूष क्या हमारी जानकारी में हैं? क्या समलिंगी संबधों में धोखे होते हैं? सुरक्षित यौन संबंध का क्या मतलब होता है?

\section{अन्त में}

सुरक्षित यौन संबंधों के बारें मे एक दूसरे से विचार करने का मतलब किसी तरह से दूसरे साथी पर अपनी जीत दिखाना नहीं होता, बल्कि दोनों साथियों के लिए योग्य परिस्थिति का निर्माण करना ही एकमात्र ध्येय होना चाहिए। लैगिंकता एक जटिल विषय है और इसमें बहुत सारे मानवीय पहलुओं का समावेश होता है। अगर दोनों व्यक्तियों में से एक को सुरक्षित यौन संबंध की अपेक्षा है और दूसरे को यह मंजूर नहीं है तो, एक समय ऐसा होता है जब दोनों में से एक या दोनों ही यौन संबंध रखने से इंकार कर देते हैं जिससे कि व्यक्तिगत एवं पारिवारिक जीवन पर बुरा असर पड़ता है। 
अभ्यास 4.6

\section{एचआईवी की जाँच और सलाहमशवरा}

उद्देश : एचआईवी की जॉच और सलाह मशवरे/कॉन्सीलिंग के महत्त्व के बारें मे चर्चा करना

साम्रगी : पॉजिएिव और नेगेटिव लिखे हुये दो पोस्ट कार्ड

समय . 2 घंटे

\section{योजना}

प्रेरक समूह को यह सुझाव देगा की वे लोग एक छोटा नाटक करने वाले है, जिसमें नाटक का दृश्य कैसा होगा वह इस नाटक के पात्रों पर निर्भर करेगा। नाटक की शुरूआत कुछ इस तरह से होगी

1. दो युवक एचआईवी जाँच के लिये एक स्वास्थ्य केन्द्र पर जाते हैं जहाँ पर स्वास्थ्य केन्द्र का एक कर्मचारी उनका स्वागत करता है। स्वास्थ्य कर्मी ने उन दोनों की अलग अलग जाँच की। जाँच के बाद स्वास्थ्य कर्मी ने उन्हें कुछ देर इंतजार करने को कहा। दोनों युवक स्वास्थ्य केन्द्र के बाहर चाय की दुकान पर बैठ कर इंतजार करने लगे।

2. अब दृश्य को यहीं रोक दें ।

3. अब समूह से पूछिये।

\section{अ. युवकों से जुड़े सवाल}

- इस युवक को ऐसा क्यों लगा कि उसे जॉच करानी चाहिए?

- जाँच करवाने के निर्णय लेने में उसे कितना वक्त लगा?

- इस जाँच से उसे क्या अपेक्षा है?

- उसे कैसा महसूस हो रहा है?
- क्या उसे डर लग रहा है या वह निश्चित है? क्यों?

- क्या उसके घर में लोगो को यह मालूम है कि वह यहाँ क्यों आया है?

\section{ब. स्वास्थ्य कर्मी से जुड़े सवाल}

- वह उस लड़के के बारे में क्या सोच रहा होगा जो उसके पास एच. आई. वी. की जाँच के लिये आया हुआ है?

- क्या वह लोगों कि मुश्किलों को हल करने में मददगार है?

4. इस तरह के सवाल समूह के सामने रखकर चर्चा करने के बाद और दो अन्य जोड़े युवकों को बुलायें उन्हे भी यही दृश्य करने को कहें पर अब उन्हें जाँच के परिणाम बता दिये गये हैं। जाँच के परिणाम पॉजिटिव और नेगेटिव दोनो को दे दिये गये है, पर ध्यान रहे कि समूह के लोगों को यह पता नही चले कि कौन पॉजिटिव और कौन नेगेटिव है।

5. एक बार फिर समूह से प्रश्न करें

- कौन पॉजिटिव और नेगेटिव है? क्यों?

- उसे इसकी खबर कैसे लगी?

- आपके अनुसार वह सबसे पहले इस जाँच के संदर्भ में किससे बात करेगा? 


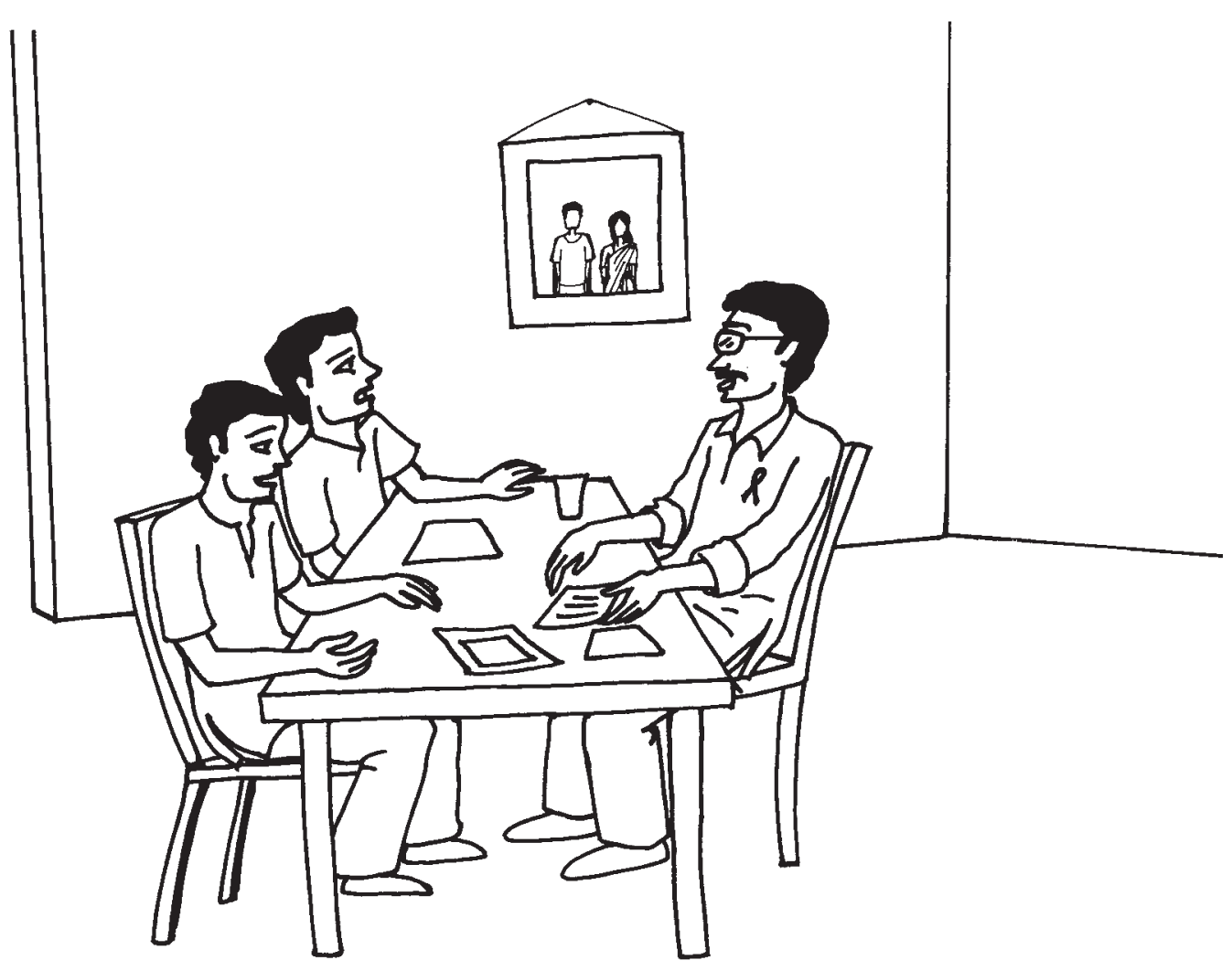

- आपको ऐसा क्यों लगता है कि जॉच का परिणाम नेगेटिव या पॉजिटिव था?

- अब जबकि जाँच का परिणाम उसे मालूम हो चुका है, आपके अनुसार अब वह क्या करे।

6. समूह को इस नाटक में निहित सच्चाई के बारे चर्चा करने को कहें ।

7. अंत में दोनों जोड़े को एक दृश्य प्रस्तुत करना है, जिसमें यह दिखलाना है कि अब भविष्य में उनके लिए क्या है?

8. नाटक में प्रस्तुत विषयों पर समूह में चर्चा करें मसलन, उन्हें क्या कदम उठाने चाहिए और भविष्य में उन्हें क्या अपेक्षाएं हैं?

\section{चर्चा के सवाल}

- एचआईवी जाँच कराने से लोग क्यों डरते हैं?

- यह जाँच सुरक्षित और गुप्त तौर पर कहाँ करें, क्या इसकी जानकारी आपको है?

- यौनरोग/एड्स से बचाव और उसके इलाज की जिम्मेदारी किसकी होनी चाहिए?
- अपने यौन साथी के साथ यौन रोग और एडस के इलाज के लिए किस प्रकार की बातचीत करनी चाहिए?

- क्या यौन रोग या एड्स संक्रमित व्यक्तियों को सेक्स करने का अधिकार है?

- अगर किसी को यह मालूम हो जाये कि उसे एड्स है तो उसे अपने साथी के साथ कैसा संबंध रखना चाहिए (पारिवारिक, लैंगिक)?

- उस दंपत्ति का जीवन कैसा होगा जिसमें कि उनमें से एक की एचआईवी की स्थिति नेगेटिव है और दूसरे की पॉजिटिव?

\section{अंत में}

आखिर में प्रेरक अभी तक की गतिविधियों का संक्षिप्त विवरण देगा, इन गतिविधियों की उपयोगिता बताते हुये उसके विकल्पो के बारे में चर्चा करनी चाहिए । प्रेरक को एचआईवी संक्रमण से बचाव पर विशेष रूप से प्रकाश डालना चाहिए, चाहे वह संकमित हो या ना हो । 


\section{में एचआईवी संक्रमित हूँ : अब क्या होगा ?}

यह अभ्यास एक ऐसी परिकल्पना पर आधारित है जिसमे एचआईवी संक्रमित होने का पता चलने पर होने वाले प्रभावों को बताया गया है।

उद्देश्य: युवा एचआईवी संक्रमित व्यक्ति के भावी जीवन के नियोजन के बारे में परामर्श देना तथा भावी जीवन में आने वाली कठिनाइयों एवं उससे निपटने के बारे में भी बतलाना ।

सामग्री: शान्त जगह।

समय: 2 घण्टे

निर्देशः बहुत से लोग ऐसा सोचते हैं कि किसी व्यक्ति को यदि एचआईवी संक्रमण हो गया है तो यह उसके जीवन का अन्त है जैसे कि :- व्यावसायिक जीवन, शैक्षणिक जीवन, व्यक्तिगत जीवन, यौन जीवन, पारिवारिक जीवन इत्यादि। हालाँकि एचआईवी संक्रमित होने से भावनात्मक स्तर पर कोई भी व्यक्ति टूट सकता है लेकिन इसका अर्थ यह नहीं कि उसका जीवन समाप्त हो गया है। प्रारम्भिक रूप से परिवार तथा दोस्तों के सहयोग से किसी संक्रमित व्यक्ति को अपराध बोध/नकारात्मक सोच से निकाल कर सकारात्मक रूप से सोचने, तथा जीवन जीने के लिये तैयार किया जा सकता है। आजकल भारत के बहुत से भागों तथा दूसरे देशों में भी बहुत सरकारी तथा गैर-सरकारी संस्थायें एचआईवी तथा एड्स के साथ जी रहे व्यक्तियों को हर प्रकार की सहायता प्रदान करती हैं, जैसे कि :- शारीरिक, विधि, स्वास्थ्य सम्बन्धी तथा पारिवारिक सहयोग इत्यादि। अतः हमें इस तरह के सभी प्रयासों का समर्थन करना चाहिये जो इस नई जीवन शैली के लिये सहायता प्रदान कर रहे हैं।

निम्नलिखित अभ्यास में भी यही किया गया है, यह एक ऐसी परिकल्पना है जिसमें कि ऐसी परिस्थितियों का धैर्य के साथ सकारात्मक रूप से सामना करने के बारे में बताया गया है। इसके अलावा यह भी आवश्यक है कि हम किसी व्यक्ति के एचआईवी संक्रमित होने तथा उसे एड्स का रोगी होने के अन्तर को जानें।

\section{प्रक्रिया}

1. समूह को बैठ जाने के लिए कहें या यदि पर्याप्त जगह हो तो उनसे लेटकर, आंखे बंद करने के लिए कहें। आप धीमा संगीत भी बजा सकते हैं।
2. सभी प्रतिभागियों को गहरी सांस लेकर शरीर को आरामदायक स्थिति में लाने के लिए कहें। फिर धीमे-धीमे सधे हुए शब्दों में निम्नवत् सफर पर चलने के बारे में बताएं; 
- चलिए, अपने दैनिक जीवन के बारे में सोचते हैं... घर के बारे में सोचते हैं... उन लोगों के बारे में सोचते हैं जो हमें अच्छे लगते हैं... उन लोगों के बारे में सोचते हैं जो हमें अच्छे लगते हैं... हमारे परिवार का कोई सदस्य... हमारा कोई दोस्त... कौन हैं वे?

- किसी ऐसे गाने/संगीत के बारे में सोचिए, जिसे आप सुनना चाहेंगे।

- तथा, कोई ऐसा खेल या गतिविधि जिसे आप करना चाहेंगे।

- तथा, आपके दैनिक जीवन में आपको क्या करना सबसे अच्छा लगता है। क्या, आज आप कुछ ऐसा करना चाहते हैं, जिसमें आपको आनन्द आए?

- चलिए अब, किसी खास व्यक्ति के बारे में सोचते हैं जैसे कि आपका प्रेमी / प्रेमिका ... या फिर कोई और ... इनके बारे में सोचने का प्रयास करें।

- आपको इस व्यक्ति के बारे में सबसे अच्छा क्या लगता है? इस बारे में सोचने का प्रयास करें कि उसे आप में क्या अच्छा लगता है?

- जब आप उस व्यक्ति के साथ होते हैं तो आपको कैसा लगता है?

- चलिए, अब थोड़ा भविष्य के बारे में सोचें ... अगले साल आप क्या कर रहे होंगे? आने वाले पांच सालों में आप कैसे होंगे? इस बारे में कल्पना करें। आप क्या कर रहे होंगे? क्या आप पढ़ रहे होंगे? व्यवसाय/नौकरी कर रहे होंगे? प्रेमी/प्रेमिका के साथ घूम रहे होंगे? अपनी कल्पना को चलने दीजिए।

- अब हम वर्तमान में आ जाते हैं ... और सोचते हैं कि आप किसी चिकित्सक के पास साधारण जांच के लिए जाते हैं। आप अकेले हैं या आपके साथ और भी कोई है? यह जगह कौन सी है (क्लीनिक या कोई स्वास्थ्य केन्द्र)। यह खाली है या यहां बहुत भीड़-भाड़ है। आपके आस-पास कैसी
आवाजें सुनायी दे रही हैं? इस जगह पर कैसी महक आ रही है? आस-पास कौन-कौन सी चीजें रखी हैं?

- चिकित्सक आपसे कहता है कि आपको एचआईवी की भी जांच करा लेनी चाहिए। आप मान लेते हैं तथा जांच परिणाम का इंतजार करने लगते हैं।

- जब आप दोबारा चिकित्सक के पास जाते हैं तो वह आपसे कहता है कि आप एचआईवी संक्रमित हैं ...

- अब क्या होगा? अब आपका जीवन कैसा होगा? क्या आप अपने जानने वालों को इस बारे में बतायेंगे? जब आप अपने साथी को इस बारे में बतायेंगे तो वह किस प्रकार की प्रतिक्रिया व्यक्त करेगा/करेगी? आपके परिवार के लोग क्या कहेंगे ? आपके मित्र क्या कहेंगे? आपके सहपाठी क्या कहेंगे? अब आपके जीवन में किस प्रकार के परिवर्तन आयेंगे?

1. प्रत्येक प्रतिभागी को इस यात्रा के पड़ावों के बारे में सोचने के लिए कुछ समय प्रदान करें। उनको याद दिलायें कि इसको अच्छे या बुरे नजरिये से न देखें बल्कि अपने जीवन के अनुभवों के आधार पर एक जानकारी के रूप में सोचने का प्रयास करें। इस कार्य के लिए 15 से 20 मिनट का समय प्रदान करें।

2. प्रत्येक प्रतिभागी से पूछें कि क्या वे वर्तमान में लौटने के लिए तैयार हैं। इसके लिए उन्हें धीमे-धीरे अपनी उंगलियों तथा टांगों को हिलाने के लिए कहें। उनसे अपने साथियों की ओर देखने के लिए कहें तथा अपनी-अपनी जगह बैठकर इस सफर के बारे में चर्चा करने के लिए कहें।

3. इसी तरह की दूसरी सम्भावना यह भी हो सकती है कि बजाए आपके आपका कोई मित्र एचआईवी संक्रमित हो गया हो तथा इससे उसके जीवन पर पड़ने वाले प्रभावों के बारे में सोचना। 
4. निम्नलिखित प्रश्नों पर चर्चा करें।

\section{चर्चा के लिए प्रश्न}

- आप में से सभी के लिए यह सफर कैसा था?

- दोनों में से किसी भी घटना-क्रम के बारे में वे क्या सोचते हैं?

- दोनों में से कौन सा घटना-क्रम आसान था तथा कौन सा कठिन?

- क्या आपको लगता है कि एचआईवी संक्रमित होने के साथ ही किसी व्यक्ति के सामाजिक जीवन का अन्त हो जाता है?
- ऐसे व्यक्ति के सामने कौन-कौन से विकल्प रह जाते हैं?

- एचआईवी संक्रमित व्यक्ति के जीवन में किस तरह के परिवर्तन आते हैं? (घर में परिवार में मित्रों के साथ समाज के साथ या कार्यालय में?

- संक्रमित व्यक्ति में किस तरह की भावनाएं जन्म लेती हैं (शर्म, गुस्सा, दु:ख, अवसाद या अन्य)?

- संक्रमित व्यक्ति के यौन जीवन पर किस तरह के प्रभाव पड़ते हैं?

\section{अंत में}

प्रतिभागियों से पूछें कि उन्हें अपने या अपने साथी (प्रेमी/प्रेमिका) के संक्रमित होने के बारे में कल्पना करना कैसा लगा? इस बात पर विशेष जोर दें कि एचआईवी संक्रमण के बाद भी जीवन उसी तरह जीया जा सकता है जैसा कि संक्रमण के पहले वह व्यक्ति जीता था। इसके लिए आज-कल विभिन्न प्रकार की दवाइयां तथा उपचार उपलब्ध हैं जो कि एचआईवी तथा एड्स के साथ जी रहे व्यक्तियों के स्वस्थ जीवन व्यतीत करने की संभावनाओं को बढ़ाते हैं। यदि संभव हो तो अपने राष्ट्र, समाज या क्षेत्र के किसी ऐसे एचआईवी संक्रमित व्यक्ति का उदाहरण दें जो कि अपने जीवन में सफल तथा स्वस्थ हो। 


\section{कौन है असली मर्द ...}

- असली मर्द गुड़ (लड़कियों की तरह बर्ताव, समलैंगिक) नहीं होता ।

- असली मर्द सिर्फ औरतों के साथ सेक्स करता है।

- असली मर्द किसी भी समय लड़ाई झगड़े के लिए तैयार होता है।

- असली मर्द को अपनी मर्दानगी साबित करनी चाहिए।

\section{या फिर ...}

- जो नजदीकी संबंधो में अपनत्व तथा समानता की भावना रखता हो।

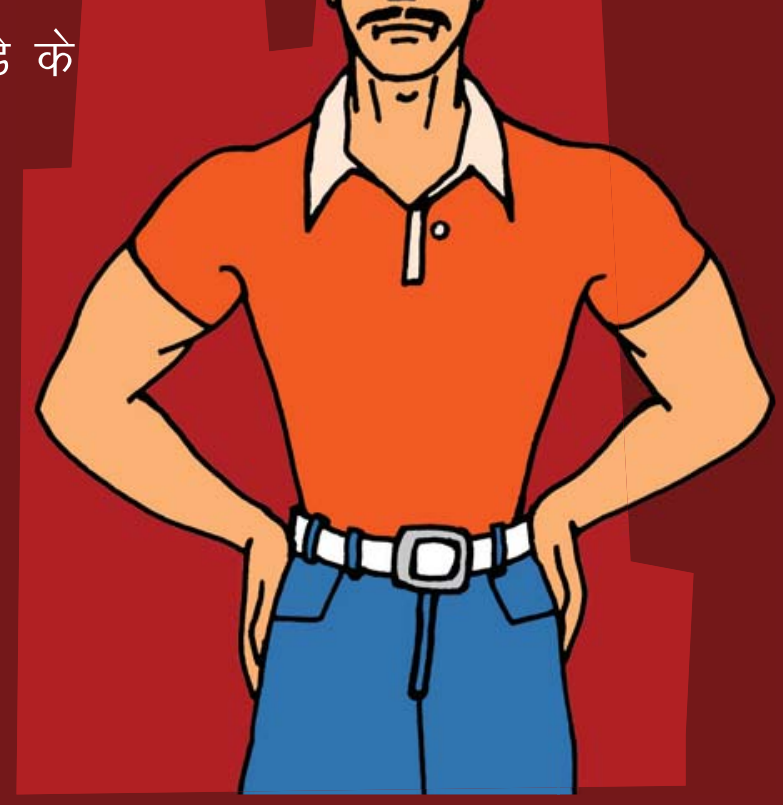

- जो पति तथा पिता होने के नाते पत्नि तथा बच्चों के प्रति अपनी जिम्मेदारी को समझता हो।

- जो अपने साथी के साथ लैंगिक तथा प्रजनन स्वास्थ्य संबंधी जिम्मेदारी को मिलकर तय करता है।

— जो अपने साथी के साथ हिंसा को बढ़ावा नहीं देता है। 